QK

569

F95G37 1922

BOT

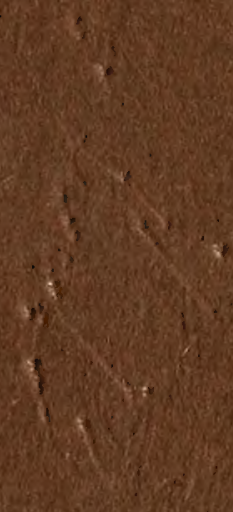




\section{SMITHISONIAN INSTiliturition LLBRARIES}
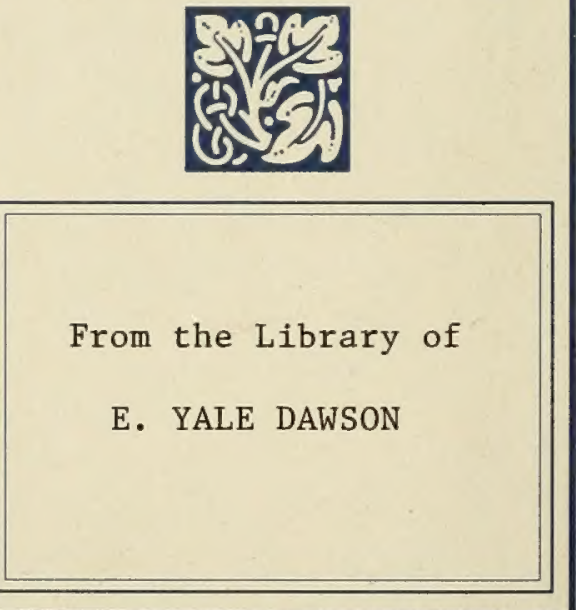

E. YALE DAWSON 


\title{
THE GENUS FUCUS ON THE PACIFIC COAST OF NORTH AMERICA
}

\author{
BY \\ NATHANIEL LYON GARDNER
}

Univeratiy of Caufrornia Publications in Botany

Vol. 10, No. 1, pp. 1-180

UNIVERSITY OF CALIFORNIA PRESS

BERKELEY, CALIFORNIA

1922 


\section{UNIVERSTYY OF OAIIFORNIA PUBLIOATIONS}

Note.-The University of Callfornia Publications are offered in exchange for the publl cations of learned societies and institutions, niversities and Ibraries. Complete lists of all the publications of the University will be sent upon request. For sample coples, lista of publications and other information, adaress the MANAGER OP THE UNIVERSITY PRESS, BERKFLEY, CAITFORIIA, U. S. A. Al matter sent in exchange should be addressed to THIE EXCHANGT DEPARTMENT, UNIVERSITY ITBRARY, BERIKATEY, OATIFORNIA, U.S.A.

WHLTAM WESLEY \& SONS, LONDON

Agent for the series in American Archaeology and Ethmology, Botany, Geology, Physiology, and Zoology.

BOTANY. -W. A. Setchell, Editor. Price per volume, $\$ 3.50$ (vol, 5, $\$ 6.00)$; beginning with volume 6, \$5.00. Volumes I, II, III, IV, and IX completed. Volumes VII, VII, and $X$ in progress.

Vol. 5. $1912-1922$.

Cited as Univ. Calif. Publ. Bot.

1. Studies in Nicotiana. I, by William Albert Setchell, Pp. 1-86. December, 1912

2. Quantitative Studies of Inheritance in Nicotiana Hybrids. I, by Thomas Harper Goodspeed. Pp. 87-168, plates 1-28. December, 1912

3. Quantitative Studies of Inheritance in Nicotiana Hybrids. II, by Thomas Harper Goodspeed. Pp. 169-188, plates 29-34. Tanuary, 1913 ........

4. On the Partial Sterility of Nicotiana Hybrids made with $N$. syluestris as a Parent, by Thomas Harper Goodspeed. Pp. 189-198. March, 1913

5. Notes on the Germination of Tobacco Seed. I, by Thomas Harper Coodspeed. Pp. 199-222. May, 1913

6. Quantitative Studies of Inheritance in Nicotiana Hybrids. III, by Thomas Harper Goodspeed. Pp. 223-231. April, 1915

7. Notes on the Germination of Tobacco Seed. II by Thomas Harper Goodspeed. Pp. 233-248. June, 1915

8. Parthenogenesis, Parthenocarpy and Phenospermy in Nicotiana, by Thomas Harper Goodspeed. Pp. 249-272, plate 85 . July, 1915

9. On the Partial Sterility of Nicotiana Hybrids made with $N$. sylvestris as a Parent. II, by T. I. Goodspeed and A. H. Ayres. Pp. 273-292, plate 36. October, 1916

10. On the Partial Sterility of Nicotiana Hybrids made with $N$. sylvestris as a Parent. III, An Account of the Mode of Floral Abscission in the F, Species Hybrids, by T. F. Goodspeed and J. N. Kendail. Pp. 293-299. November, 1916

11. The Nature of the $\mathbf{F}_{1}$ Species Hybrids between Nicotiana sylvestris and Varleties of Nicotiana Tabacum, with Special Beference to the Conception of Reaction System Contrasts in Fieredity, by T. H. Goodspeed and $\mathrm{R}$. $\mathrm{E}$. Clausen, Pp. 301-346, plates 37-48. January, 1917 .

12. Abscission of Flovers and Fruits in the Solanaceae, with Special Reference to Nicotiana, by John N. Isendall. Pp. $347-428,10$ text figures, plates 49 . 53. March, 1918

13. Controlled Pollination in Nicotiana, by Thonas Harper Goodspeed and Pirie Daviason. Pp. 429-434. August, 1918

14. An Apparatus for Flower Measurement, by T. H. Goodspeed and R. E. Clausen. Pp. 435-437, plate 54, 1 figure in text. September, 1918

15. Note on the Bffects of Illuminating Gas and Its Constituents in Causing Abscission of Flowers in Nicotiana and Citrus, by T. H. Goodspeed, J. M. McGee and R. W. Hodgson. Pp. 439-450. December, 1918

16. Notes on the Germination of Iobacco Seed. II, Note on the Relation of Iight and Darkness to Germination, by T. Harper Goodspeed. Pp. 451455. April, 1919

17. Inheritance in Nicatiana Tabacum, I, A Report on the Results of Crossing Certain Varieties, by Willian Albert Setchell, Thomas Harper Goodspeed, and Roy Firood Clausen. Pp. $457-582,2$ figures in text, plates 55-85. April, 1922 
LIBRARY OF

E, YALE DAWSON 
QK

$$
\begin{aligned}
& 569 \\
& F 95 G 37 \\
& 1922
\end{aligned}
$$


THE GENUS FUCUS ON THE PACIFIC COAST OF NORTH AMERICA

BY

NATHANIEL LYON GARDNER

PUY 121999

LIBRARIES 


\section{University of California Publications in Botany}

Vol. 10, No. 1, pp. 1-180, plates 1-60

Issued April 25, 1922 


\section{THE GENUS FUCUS ON THE PACIFIC COAST OF NORTH AMERICA}

BY

NATHANIEL LYON GARDNER

CONTENTS

Historical Review

Basis of Classification

Diagnostic Characters 12

Diagnosis of species

Literature Cited

57

Explanation of Plates 


\section{INTRODUCTION}

The genus Fucus, although among the earliest established genera of algae, having been studied on the Atlantic and Aretic coasts of Europe by most of the algologists since the days of Linnaeus, is, nevertheless, even today, a genus in which the limits of the species, not only in European waters but also in those of Asia and America, have not been clearly defined. The flattened, more or less flabellate and mostly dichotomously branched fronds, together with the very constant character of the formation of eight viable eggs in oögonia borne in cavities in the modified ends of the fronds, quite definitely delimit the genus from all other genera of algae; but the discovery of single characters, or combinations of characters, sufficiently stable to serve in delimiting the multitude of species and forms has been a matter much more difficult of attainment. About twenty-five species and over forty varieties and forms have been previously proposed. From time to time species have been reduced to varieties and to forms, and these have in turn been raised to the rank of species, and the species have been interchanged, according to the conceptions of the different investigators of the group. This has gone on with increasing complexity and there seems never to have been a time when more confusion existed in regard to the disposition of the Fucus flora, particularly that of the Atlantic and of the Arctic waters, than the present. The confusion is due to a variety of causes. One of the chief difficulties one encounters in trying to get an understanding of the conceptions of the early writers concerning certain species is the incompleteness of the descriptions, adequate at the time to distinguish fairly well the few forms then known, but wholly inadequate to serve in the separation of species as limited by present day usage. Coupled with the brevity of the descriptions, one often encounters an added difficulty in the nature of poorly prepared, and for the most part, fragmentary specimens preserved as types, if indeed any at all have been preserved. I have quoted some of these early descriptions under proper headings, and have also presented illustrations of some of the few type specimens, which will serve, in some degree, to show the existing state of affairs.

Since the days of Linnaeus our conceptions of species have been and still are changing. Formerly larger units were grouped under a single concept, and a few words were sufficient to embody the concept. The general tendency has been to break up the larger units, assigning 
to each kind fewer and fewer characters. Today, with the coming of the geneticist, the concept of a species is becoming so limited that for practical purposes, if carried to the extreme, it has but little value; nevertheless it cannot be ignored. It is now generally conceded that new kinds of organisms have arisen, and are still arising through permanent modifications appearing in the offspring which produce an individual more or less different from the parent, and that these modifications are heritable and stable. The causes of the modifications that bring about such changes have not yet been assigned. According to Darwin, the modifications are small and when the succession of infinitesimally small modifications in the suppression or development of a structure has proceeded long enough the offispring becomes a species. According to De Vries, the modifications may be relatively great, so that one may readily detect the difference between the parent and the offspring in a single generation. The offspring becomes a new species at once. Possibly both these ideas are correct, but in some groups of individuals constituting entities, the forces acting to bring about the changes operate slowly. whereas in others they are accelerated and the resulting changes are marked at once. In either case, it is left to the keenness of the observer to detect the differences. And the difficulty does not end with that; it can not, in the nature of things, until a specific standard is set up and agreed upon. Darwin never suggested by how much one group should differ from another in order to constitute a species.

Another complicating set of factors always enters into the situation in a rapidly changing, or species making group, to further the difficulty of detecting the limits of species. The individuals of every generation of all groups of organisms may vary in one or more morphological characters, but these differences are not heritable. This is spoken of as fuctuating variation. The problem which one usually has to determine in placing an individual is whether the dominant character or characters is due to fluctuating variation or to a change which has become fixed. The fluctuating variation may often be much greater than the permanent difference between two species. Thus the average width of the fronds of a species of Fucus (a) may be $10 \mathrm{~cm}$., and that of another (b) may be $15 \mathrm{~cm}$. Some individuals in $(a)$ may possibly be wider than $15 \mathrm{~cm}$. and some in (b) may be narrower than $10 \mathrm{~cm}$.

The causes of the differences in characters in fluctuating variation may be grouped under two categories, one physiological and the other environmental. For example, two Fucus plants of the same lineage may have equal environmental conditions and be equal in initial size, 
but be decidedly different at maturity in a particular character or characters, the differences being due to causes physiological and not yet explainable, and the deviation from the normal not be heritable. Again two plants of the same lineage may by chance get started in different habitats in the same locality and at maturity be quite unlike, e.g., in size, one typical of the species growing in a belt of optimum conditions for that species, and the other a dwarf merely, due to being removed from such a belt of optimum growth.

In passing I may say that the belt of optimum growth is not the same for all species of Fucus. Some species or forms thrive only in the extreme lower littoral belt, others in the middle, and still others in the narrow belt along the extreme high-tide limit. It cannot be argued that the species along the extreme high-tide limit are necessarily there by chance and represent dwarf specimens. Fucus evanescens f. robustus may be found in such a belt extending along the coast for miles where no other species or specimens exist, and yet the rock ledges in such localities are continuous from far above the high-tide limit to below the low-tide limit. Specimens of any species may, however, be stranded in the upper tide limits, e.g., on mud flats, and may leave offspring which may develop into seemingly distinct forms. I have seen this demonstrated to my entire satisfaction in the case of the so-called nanus forms. These forms are merely transitory. I have seen acres of territory bearing such plants of any species that happened to be growing in the vicinity, the most of which never come to the fruiting period and are always more or less, usually profoundly, distorted and dwarfed. Thus it is quite essential to know the habitat of a plant when attempting to place it.

In this paper I am describing three new forms of Fucus seemingly quite distinct from each other genetically, and apparently distinct from all other entities, but which possibly may be only environmental forms. They all fruit abundantly and, to all appearances, from observations made during only one season, they perpetuate themselves and remain constant. These are forma cuncatus, forma depauperatus, and forma oregonensis of Fucus evanescens, found growing in Coos Bay, Oregon. They are profoundly different in shape, size, and color from any forms growing outside of the mouth of Coos Bay. A strong tide sets into the bay and floating specimens may be readily carried for miles in either direction. The determination of the lineage of such forms constitutes a real problem which, in each case, wherever it may arise, can only be solved by experimentation. In a place like Coos Bay, the demonstration could fairly easily be made. 
For many years I have observed, in their native habitats, extensive beds of Fucus growing on our western shores extending from central California to Sitka, Alaska, and have been much confused and deeply perplexed in trying to determine the best disposition to make of the multitude of forms here represented. The range for the genus extends from Oil Port, San Luis Obispo County, California, its southern limit as at present known, into the Arctic Ocean, and is practically unbroken. In the southern portion of the range the problem is comparatively simple, there being but few forms represented. The complexity increases northward, and the optimum for luxuriance in growth of numbers of forms and of individuals seems to be in the general latitude of Sitka. Alaska.

I have come to the conclusion that we have in this genus an example of extreme plasticity, in which the forces at work breaking up continuity are vigorously active. Plants with new combinations of characters are arising and, to still further complicate the matter, these probably hybridize with one another.

For ultra popular usage, a very few species, perhaps four, would thoroughly suffice to include all of the forms of the genus, e.g., $F$. serratus, $F$. vesiculosus, $F$. spiralis, and F.evanescens. Morphologically serratus is obviously distinct, vesiculosus is always dioicous, while all others are synoicous. Forms which have been included even under spiratis and evanescens might be confused because of overlapping characters. Such a disposition would doubtless, for scientific usage, meet with hearty disapproval. On account of the nature of the genus, any disposition at present can only be approximate in the face of our vastly incomplete knowledge concerning a variety of points.

Without further delay, I am arranging our multitude of forms under five rather comprehensive species, viz., $F$. furcatus Ag., $F$. nitens nob., $F$. edentatus De la Pyl., $F$. membranaceus nob., and $F$. evanescens Ag. These I have so diagnosed as to make them include all the forms which I have grouped around them, and have designated the group as species major. Under each species major, respectively, I have grouped 13, 0, 5, 6, and 21 forms which I feel quite convinced are entities, giving rise to others of their kind in successive generations in the same manner as does any other species; however, my investigations may not have been extensive enough as yet to prove this statement. These forms I am designating as species minor and, following customary usage, I am calling them formae of the respective species, awaiting further investigation and experimentation to prove the 
validity of their specific rank, or that they represent merely individuals with inconstant and fluctuating characters, due to environmental influences.

\section{Historical Review}

Kjellman (1883, p. 203) remarks as follows concerning some of the numerous forms which he has deseribed:

I have set down here the same forms that I have before endeavored to distinguish and to define. They are certainly connected by numerous intermediate forms, but they deserve, however, to be mentioned specially, because they show the limits and directions of the variations of the species and differ somewhat with regard to biology and geographical distribution.

Yendo (1907, p. 16) has assembled several forms from the Japanese waters and has allied them, according to his conception, with certain of Kjellman's forms of $F$. evanescens, at the same time expressing his disbelief in ascribing definite identities to such plants: "Besides the above mentioned formae others might be pointed out. It would, however, be unimportant to add to algological literature more formal names, established on what I regard as invalid forms."

I find it not wholly a simple matter to justify the selection of the species major mentioned above as seemingly the most suitable to include our flora as against certain others which might have been selected. I also feel much handicapped in not having had direct contact with more European material for comparison. I have been compelled to rely largely upon descriptions.

Most of the earlier collections from our coast were assigned to European species. Two species, however, viz., F. furcatus Ag. (Sp. Alg., 1820, p. 97) and $F$. evanescens Ag. (loc. cit., p. 92) bave been described from the waters of the North Pacific, the former is said to have come from Unalaska and the latter from Kamtschatka. Agardh assigned these localities on the authority of Chamisso, who travelled along our coast in 1816 as far south as San Francisco. Some doubts have arisen as to the localities from which he obtained the material upon which Agardh based his species.

Harvey (Bot. Beechey, 1833, p. 163, and 1841?, p. 407) was apparently the first to accredit $F$. furcatus Ag. to the Pacific coast of North America. He based his judgment upon material collected at San Francisco, California, by Dr. Sinclair. I have not seen the specimen, nor have I any further information concerning it, but it seems quite probable, as may be seen later, that his determination was correct. 
J. Agardh (1848, p. 209) quotes Chamisso's Unalaska specimen and Sinclair's San Francisco specimen under $F$. furcatus Ag., at the same time reducing $F$. edentatus De la Pyl. (1829, p. 84) to synonymy with $F$. furcatus Ag. This seems to have been the beginning of the confusion of the two species which has not, up to the present time, been completely cleared up.

Kuetzing (1849, p. 591) gives a brief diagnosis of the species as follows: "F. phycomate lineari enervi plano furcato, digitali; carpomatibus terminalibus planis 1-11/2" longis, phycomate latioribus." "Ad oras occidentales Americae borealis, ad Unalaschkam, Californiam." In Tabulae Phycologicae, 1860, plate 17, figure II, he gives a diagram of a portion of a plant from "Unalaschka" which shows the receptacles to be 3 to $4 \mathrm{~cm}$. long and very sharply pointed. This figure was probably sketched from a portion of the type material collected by Chamisso and, although it differs considerably from Agardh's figure (Icon. Ined., pl. 14), it may well represent a more typical portion of a plant than Agardh's.

Ruprecht (1851, p. 346) has the following to say concerning $F$. evanescens $\mathrm{Ag}$. and $F$. furcatus Ag., mentioned above:

Ueber Fucus evanescens und furcatus kann ich jetzt, nach Einsicht der Original-Exemplare in Chamisso's Herbarium, ein sicheres Urtheil abgeben. Der erstere ist ein höchst unbedeutende, keineswegs beständige Form von $H$. vesiculosa und kommt nicht selten unter den Ochotskischen Exemplaren vor; die an den Fruchtzweigen verschwindende Blatt-Rippe bezeichnet diese Form am wenigsten; Chamisso's Pflanze stammt von Redowski, von der Westkïste der Ochotskischen Meeres, nicht aus Kamtsehatka.

Fucus furcatus C. Ag. ist eine selbständige Art, wächst aber nicht bei Unalaschka, sondern in Nord-Californien bei Ross, woher ich neuerdings mehrere Exemplare sah. Von eben daher hat auch, nach meinem Dafürhalten, Chamisso seine Pflanze mitgebracht; die beigelegte Etiquette mit "Kamtsch?" bezeichnet, beweist, dass er selbst iber ihren Fundort im Zweifel war.

Fucus furcatus J. Ag. (Sp. Alg. I, p. 209) ist ein ganz andere Tang (eine Var. von $\boldsymbol{H}$. vesiculosa?), als die gleichnamige, in den Icon. Alg. ined. Tab. 14 abgebildete Original-ptlanze.

Harvey (1862, p. 163) again ascribes $F$. furcatus $\mathrm{Ag}$. to the Pacific Coast in determining Lyall's collections from Vancouver Island. He remarks (loc. cit.): "My $F$. Wrightii from Japan scarcely differs. I fear that neither ought to be regarded as other than local varieties of $F$. vesiculosus, which sometimes, even in Europe, occurs with as narrow fronds. The elder Agardh's figure above quoted," that is, Icon. Ined., pl. 14, "is worthless as a guide to the species described by J. Agardh." Fucus Wrightii is now known to be a species of Pelvetia 
(cf. Yendo, 1907, p. 20) which again leaves the status of $F$. furcatus in doubt so far as the Vancouver Island specimen is concerned.

These statements of Ruprecht concerning $F$. furcatus Ag. doubtless, as pointed out by Kjellman (1883, p. 205) and by Börgesen (1902, p. 465), influenced J. Agardh (1868, p. 40) to describe $F$. furcatus Ag. and $F$. edentatus De la Pyl. again as separate species. Kleen (1874, p. 29) subordinates $F$. edcntatus De la Pyl, to F. furcatus Ag. Kjellman (1883, pp. 204, 205) takes up F. edentatus De la Pyl., accepting J. Agardh's latest interpretation (loc. cit.) of the distinctness of the two species and reduces Kleen's $F$. furcatus to synonymy, remarking in this connection :

The identity of the Fucus in question ( $F$. furcatus) occurring on the north coast of Norway, with Fucus edentatus De la Pyl. appears to me to be beyond a doubt. I have not, among the great number of specimens from Norway and the northeastern coast of North America examined by me found any that agree fully with Agardh's figure of $F$. furcatus. I have thought best to follow J. G. Agardh's later exposition, regarding $F$. edentatus as specifically distince from F. furcatus $\mathbf{A g}$.

Börgesen (1902, p. 465) has made the following disposition of the Fucus forms on the Faeröe Islands. He, with Foslie (1886, p. 109) and Rosenvinge (1893, p. 834), takes up the $F$. inflatus (L.) Vahl (Fl. Dan., pl. 1127) as the species under which should be placed De la Pylaie's $F$. edentatus, and also reduces Kleen's $F$. furcatus, mentioned above, to synonymy with $F$. inflatus, as well as J. Agardh's $F$. furcatus to synonymy with $F$. inflatus f. edentatus (De la Pyl.) Rosenvinge.

Farlow (1881, p. 102) accredits F. furcatus to the New England coast, giving as further distribution, "Northern Europe; Aretic Ocean; North Pacific" and cites no. 108 in Farlow, Anderson, and Eaton's Algae Exsiccatae Americae Borealis. Again (1889, pp. 6, 7) he disposes of $F$. furcatus on the Atlantic coast in the following language:

The F. furcatus of Marine Algae of New England is without doubt the same as $F$. edentatus of Newfoundland, formerly united with $F$. furcatus Ag., of the North Pacific, a species to which was also referred a Fucus of the northern coast of Norway. Later the two species were kept distinct by J. G. Agardh, and Kjellman in the Algae of the Arctic Sea referred the so-called $F$. furcatus of Norway and Greenland to $F$. edentatus where our common New England alga also belongs, although the Fucus furcatus of our west coast may perhaps be the same as the original $F$. furcatus of C. A. Agardh's Icon. Ined.

Acceptance of the ideas set forth by Foslie, Farlow, Rosenvinge, and Börgesen would quite effectively eliminate $F$. furcatus Ag. from the Atlantic and Arctic waters. It remains now either to reëstablish or to eliminate this species entirely. I propose to reëstablish it with 
certain emendations, using as a basis for my decision Ruprecht's statements (loc. cit.) supported by Farlow's contention (loc. cit.) that furcatus belongs primarily to the Pacific coast of North America. Börgesen (1902, p. 465) recognizes the priority of Agardh's furcatus (1820) over De la Pylaie's edentatus (1829), but rejects the name furcatus on the ground, as he says, that "the specimen of this species which C. Agardh described was-judging especially from his figurea small, poorly developed one (apparently a transitional form to $f$. distichus)." The type specimen of $F$. furcatus is in the Herbarium of J. G. Agardh, no. 00279 (Type!) Unalaska, Ex. Herb. C. Ag., according to Professor Setchell. I have reproduced Agardh's figure on plate 1, figure 1, and it certainly is not a characteristic portion of any species of Fucus, but represents, as I think, a proliferous portion of a plant. I have seen many specimens of proliferations similar to the one represented by Agardh (cf. plate 2), taken from dried herbarium specimens collected by Setchell at Fort Ross, the probable type locality. It seems to me that the evidence is sufficiently ample to warrant the assumption that Agardh's delineation, poor and uncertain as it is, refers to a plant on the California coast.

\section{Basis of Classification}

I am using as a fundamental distinguishing character of $F$. furcatus as a species major the presence, usually, of a large number of eavities in the fronds which are completely closed. These are, I suspect, what J. Agardh (1868, p. 38) refers to under "Cryptostomata immersa saepe numerosa, plurima diu clausa." I have investigated the origin of these structures and find that they originate as do the conceptacles and ordinary cryptostomata, as shown by Bower (1880). A surface cell near the growing point in the terminal depression breaks down and the eavity is formed as described by Bower, but unlike the conceptacles and the eryptostomata no ostiole remains. The cavity is completely arched over, and no paraphyses develop. This process appears to be an evolution in the direction of reduction. To these cavities I am applying the term caecostomata, as suggested by Professor Setchell, to distinguish them from the true eryptostomata with ostiole and paraphyses. In $F$. furcatus $\mathrm{f}$. typicus, as $I$ am limiting that species, they are very abundant, up to four hundred and fifty in each square centimeter, and there are no cryptostomata. In certain other forms of furcatus there are a few cryptostomata perfectly formed very early. The caecostomatal character seems quite effectually to mark off 
a distinct group, the distribution of whose members extends as far north as Sitka, Alaska, with the southern limit in San Luis Obispo County, California. Along with this character is usually found a decided olive green color.

Fucus nitens refers to a group of plants growing in San Francisco Bay, which seems not to fit in well with any other described speeies. It doubtless is an offshoot of the furcatus group, and very probably hybridizes with it.

The decision in the selection of edentatus as against inflatus for the specific name seemingly best suited to certain of our narrow forms is based upon the study of the original descriptions and illustrations of the type specimens of each species.

Fucus inflatus dates back to Flora Lapponica, of Linnaeus, 1737. The diagnosis as given by Linnaeus in Species Plantarum, 1753, p. 1159, is: "Fucus fronde bifida; laciniis ovato-lanceolatis inflatis apice divisis." This will suffice in part for any species of Fucus that has been proposed, just as well for one as for another. Through the kindness of Dr. M. A. Howe, I have a habit sketch made by him of two small parts of plants in the Linnaean Herbarium which, according to Dr. Howe, is all that is left to indicate Linnaeus' conception of this species. These small bits are sterile and Dr. Howe remarks, "The enlargements, to which it owes its name, are possibly inflations which have been flattened down in pressing, but I find no certain evidence of this in the Linnaean specimen." Thus neither the description nor the specimens seem to me in the least adequate to give one even an approximate idea as to the concept of Linnaeus regarding this species. Vahl, in Flora Danica, plate 1127, gives a diagrammatic sketch and a brief diagnosis showing his conception of the species. The sketch is certainly of a plant quite different from that of Linnaeus. Of late years there has been as great confusion in the use of the term inflatus as in the use of furcatus. Foslie (1886, p. 109) proposes $F$. inflatus (L.) Vahl for certain narrow forms. Kjellman (1890, p. 11) adopts the name for a group of plants which he first separates into two groups, $\alpha$ Finmarkicus and $\beta$ Nordlandicus, under which he describes nine different forms. He left no illustrations and made no attempt to show their relation to other described forms. Rosenvinge (1893, p. 834) uses the name inflatus to include $F$. edentatus De la Pyl., $F$. evanescens Ag., and F. linearis Ed. De-Toni (1895, p. 195) accepts the group as proposed by Kjellman. Börgesen (1902, p. 465) uses the term inflatus to include certain Faeröe Island plants which he designates as 
formae edentatus, distichus, and linearis. Setchell and Gardner (1903, pp. 280, 281) used the term infatus to include certain plants in the Puget Sound region which were placed under the forms edentatus, Tinearis, and filiformis of this species.

The type of F. edcutatus De la Pyl. is in the herbarium of the Inseum of Paris. Dr. M. A. Howe has examined and photographed this type specimen and through his courtesy I have received a print of the negative, which I have reproduced on plate 60 , figure $1 . \quad$ I have examined dried specimens from the north Atlantic coast of a relatively narrow form, which are smooth and black on drying and free from caecostomata, which seem to me to correspond with the description and illustration of the type of edentatus. Several of our forms which have been previously associated with $F$. inflatus seem, on close comparison with these eastern specimeus, to belong with the edentatus lineage rather than with the much more vague inflatus lineage, and I am placing them in accordance with this view.

I am using the term edentatus as a species major to include mostly narrow, smooth, and glossy forms, almost black on drying, practically free from caecostomata and with few cryptostomata.

There are remaining certain northern forms which do not seem to fit in well with any of these groups. They have more or less membranaceous fronds, with no eaecostomata, are usually decidedly rellowish in color, have the cryptostomata most abundant on the terminal and subterminal segments and these cryptostomata protrude on drying. These I have grouped under the species major which I have designated as membranaceus.

In treating of the Fucus flora of the northwest coast of North America, Setchell and Gardner (1903, p. 281) adopted Fucus evanescens as a satisfactory name to include most of the forms then known in that region. This species thus is given the widest range in distribution of all the described species, since this name has been applied to plants of both shores of the North Atlantic and of the North Pacific as well as of the Arctic oceans. One of the chief characters upon which this species is based, viz., the vanishing of the midrib in the terminal and subterminal segments, is as fluctuating as any other character. It may be seen on plate 35 that the midrib extends to the very tips of the segments. This plate represents a plant from Spitzbergen determined by J. Agardh. Three fragments of plants, no. 132622 of the Herb. Univ. Calif., from the same region collected by Kjellman likewise show the midrib quite distinctly. Plate 1, figure 2, 
represents the original figure of Agardh and shows very little midrib in the terminal segments nor in other parts of the frond. My own experience with this character is that it cannot be relied upon as having very pronounced diagnostic value, except in a few eases. The type locality is said to be Kamtschatka and, according to Setchell, the type specimen is in the herbarium of J. G. Agardh, under no. 00299, with a query. Kjellman has described ten forms of evanescens and reduced J. Agardh's F. bursigerus to a form of the same species. Stroemfelt (1886, p. 35) added f. dendroides. De-Toni (1895, pp. 201-203) accepts all these forms as valid. Setchell and Gardner (1903, p. 283) added two more. Most of Kjellman's forms have been recognized with some degree of certainty in the northern portion of the range considered here. The plants so listed, however, seem almost invariably to be more robust than those of Kjellman's finding. On the whole, the species as understood in Europe, seems to me to be the best suited to include the most of the forms of Fucus growing in the North Pacific region, having more or less coriaceous fronds for the most part robust, with a brownish or yellowish color, with relatively few eryptostomata.

\section{Diagnostic Characters}

In attempting to diagnose our forms, I have made use only of the gross morphological features. I think, however, that it would be quite within the bounds of possibility that histological characters could be made use of effectually in determining limits. The shape and size of the oogonia and antheridia vary considerably, but I have not carried the study far enough to determine whether a fixed difference may be present and detectable, or whether the difference may be due simply to fluctuating variation. The only satisfactory way to prosecute such study is by the use of fresh or fixed material.

The following characters have been used in rendering the diagnosis in this work:

The holdfast, in all cases, is a solid, somewhat fibrous disk, larger or smaller according to the species and to the nature of the substratum and the environment, which serves to anchor the plant. The plants growing on the open coast, exposed to heavy surf, usually have the most robust holdfasts. Those plants growing on wood in quiet waters usually have smaller, poorly developed ones. Plants growing under the latter conditions usually do not persist long.

The stipe is a term rather loosely applied in this group. Strictly speaking, it should apply to that portion of the frond between the 
holdfast and the first forking, varying in different species from one centimeter to five centimeters in length. As the plant grows older the alae wear away, more or less, and the midribs among the segments, or branches, thicken; flat at first, they become more nearly cylindrical and virtually become a part of the stipe. The length of the stipe and its degree of flatness aqre characters of considerable value in determining species.

The term segments is understood to apply to those portions of the frond between each forking. Characters of the segments which are of morphological value in determining the species are the general shapes, the most prominent of which are linear and euneate, thickness and width of the alae, and the extent of the development of the midrib. The nature of the terminal segments is often of pronounced value.

The growing point is located at the base of a flattened, more or less crescent-shaped pit of considerable depth at the outer ends of the terminal segments. They are thus situated back of what appear to be the ends of the segments. The nature of these terminal depressions is of some diagnostic value.

Receptacle is a term used to designate the metamorphosed free ends of the terminal segments, for the purpose of developing the reproductive organs, oögonia and antheridia. These organs are borne along with sterile filaments, the paraphyses, in cavities, the conceptacles, scattered in various ways over the surface of the receptacles. The receptacles vary much in shape, even on the same individual, as well as on different individuals and on different species. Some are complanate and possess little mucilaginous substance, others are much swollen and filled with the same substance and still others are inflated with gases. Receptacular characters, though variable, are of considerable value in determining species.

Cryptostomata, when applied to the genus Fucus, is a term that has been applied to certain cavities scattered promiseuously, or arranged more or less definitely, over the whole frond except the stipe and the holdfast. They are not confined to this genus alone, however, but have been more thoroughly investigated in Fucus than in any of the other genera. They appear in other members of the Fucaceae, and also in several genera of the Laminariaceae. The eavities may or may not have sterile, hyaline hairs, paraphyses, in greater or less profusion and, when present, extruding at times through an opening at the top called the ostiole. These paraphyses disintegrate sooner or later, and even the whole cryptostomata may disappear entirely as the lower parts 
of the front metamorphose. The phylogeny, functions, and development of the cryptostomata have been the subjects of considerable discussion and investigation among algologists. It is not my purpose here to go into an extensive discussion of the literature on these subjects. A few statements, however, may be of service in this connection.

Bower $(1880$, p. 36) briefly reviewed the literature that had been published on the investigations of the subject of the cryptostomata up to that date, bearing particularly upon their origin. Oltmanns $(1904,1905)$ has given a much more exhaustive account of opinions and investigations, including his own, on all phases of the subject. Regarding the phylogeny and functions of these organs, the investigations up to the present time seem to have been too meager to warrant any satisfactory general conclusions. That which seems to me to be the most satisfactorily assignable function of the paraphyses is one suggested to me by Dr. Setchell, first mentioned by Reinke (1875, p. 230), viz, their connection with nutrition. Reinke compares them to root hairs of the higher plants, serving to increase the absorbing surface. In whatever species they occur, they originate and are most vigorous in meristematic tissue, either in ephemeral or in perennial species. They would thus seem to be homologous to root hairs in the higher plants, exposing a greater absorbing surface at the time and in the place of greatest need for food, soon disappearing after having served their purpose.

So far as the genus Fucus is concerned, the investigations of Bower (loc. cit.) seem definitely to have settled the question of the origin and development of the conceptacles as well as the cryptostomata. He shows that they originate just back of the growing point, in the depressions at the apices of the fronds, by the failure of a single surface cell to divide horizontally, and its subsequent disintegration. From this beginning he carefully traces and figures the enlarging cavity resulting, and the differentiation of the reproductive organs and sterile hairs. I have verified the results of. Bower's investigation so far as the initial step in the formation of these organs is concerned.

Having frequently noticed forms of Fucus, particularly from the region of Puget Sound southward to the southern limits of its distribution, in which the eryptostomata were deep-seated, completely closed, and destitute of paraphyses, I was prompted to investigate their origin with a view to determining the use to which this eharacter might be put in placing the species. Several genera of the Fucaceae 
have the conceptacles promiscuously distributed over practically the entire frond. In others, e.g., Fucus, Pelvetia, the reproductive structures are limited to the metamorphosed ends of the segments. The cryptostomata in the genus Fucus are so intimately associated with the conceptacles, both being the same in their method of origination and similar in their form, as to make it seem quite logical to conclude that the are degenerated conceptables. Indeed Bower has so considered them, speaking of them as "incomplete sexual conceptacles." Adopting this line of reasoning one may readily conceive that it is only a step further in the line of reduction evolution to produce a plant in which none of the cryptostomata develop paraphyses and all remain completely arched over, leaving no ostioles. Fucus on the west coast of the United States abounds in forms having structures of this nature. Such cavities I have designated caccostomata as distinguished from cryptostomata, and I am using them as one of the distinguishing characters of a species major, viz., Fucus furcatus (see above, p. 9). The next stage in reduction would be the complete elimination of both caecostomata and cryptostomata, and approximately this condition exists in the species major, Fucus edentatus.

The color character is of considerable value in determining species. This character, however, is subject to a certain amount of variation and cannot be solely relied upon. The color of an individual may vary with age and with exposure. In dense clusters of plants the lower portions have a more intense color than the upper part. All species are darker on drying than in the living state, and the color distinction between species may be more pronounced and constant in the dried specimens than in the living plants.

The habitat of a plant cannot be said normally to be a specific determinant, though a knowledge of the normal habitat of a plant, if markedly different from that of another plant, may assist in establishing to a certainty the belief in the entities of two closely related forms. Fucus evanescens f. robustus is never to be found growing outside of a narrow belt along high-tide limit. F. membranaceus $f$. latissimus inhabits exclusively the lower littoral limit. If there were nothing in gross morphology to distinguish these two species, this fact alone would lend plausible support to the belief that the two are distinct entities, each with a separate lineage. 


\section{Fucus furcatus Ag.}

Plate 1, figure 1

"Fronde lineari enervi plana furcata, receptaculis terminalibus." "Ad Unalaschka, Chamisso."

"Vidi in herbario Chamissoi."

"Frons plana, digitalis, linearis, parum dilatata, lineam vel sesquilineam lata, 2-3 furcata, omnino enervis. Receptacula plana, unciam vel sesquiunciam longa, fronde latiora, semper furcata, segmentis attenuatis obtusis, tuberculatis; tuberculis pertusis continentibus glomerulos gelatinoso-filamentosos, in quibus capsulae ovatae limbo hyalino circumfusae numerosae nidulantur. Color exsiccatae nigerrimus. Substantia cartilaginea, exsiceatae rigida."

Agardh, Sp. Alg., vol. 1, 1820, p. 97.

Fronds usually rigid, often arborescent, more or less cartilaginous, for the most part decidedly mucilaginous, regularly dichotomous, olive green to yellowish; segments usually relatively long, slightly euneate to linear, in some cases decidedly crisped, midrib prominent and percurrent and often yellowish, eaecostomata few to very many; receptacles for the most part complanate, sometimes tumid, often decidedly yellowish.

Growing in the middle and lower littoral belts. From Sitka, Alaska, to Oil Port, San Luis Obispo County, California.

Agardh, loc. cit., Icon. Ined., fase. 2, 1821, pl. 14, Syst., 1824, p. 279 ; J. Agardh, Sp. Alg., 1848, vol. 1, p. 209.

For a discussion of this species major see page 9.

\section{Fucus furcatus f. typicus f. nov.}

Plates 2 and 3

Frons paullo caulescens, paululum cartilaginosa, 20-30 $\mathrm{cm}$. alta. regulariter dichotoma, obseure olivaceo-viridis, siccata atra, segmentis planis, linearibus vel cuneatis, $10-18 \mathrm{~mm}$. latis, costa distincta, percursa, caecostomatibus $250-300$ in quoquo $\mathrm{cm}$. quadrato, parvis, ineonspicuis, cryptostomatibus nullis vel sparsissimis; reeptaculis, complanatis, saepissime late linearibus, 4-6 $\mathrm{cm}$. longis, saepissime bifidis, apicibus acutis; conceptaculis numerosissimis et comparative parvis.

Growing on boulders and rock ledges in the middle of the littoral belt. From the Strait of Juan de Fuca to central California.

Type, Setchell, no. 1691 (Herb. Univ. Calif., 99171), Fort Ross. California, June, 1897. Gardner, no. 2187 (Herb. Univ. Calif,, no. 201151), Moss Beach, San Mateo County, California, April, 1910.

Fucus evanescens f. typicus, Collins, Holden and Setchell, Phye. Bor.-Amer. (Exsice.), no. 1338. Fucus inflatus f. edentatus, Setchell and Gardner, Alg., N. W. Amer., 1903, p. 280. 
The Fucus furcatus of Tilden's American Algae, no. 234, as to the specimen distributed in Professor Setchell's copy, is not typical of this species as found on the California coast. The specimen is only a small portion of a plant. It is mature, considerably worn and battered, and has comparatively few caecostomata. The distribution is probably to be referred to f. typicus, but it is desirable to consult other specimens of the distribution before deciding definitely.

This form is abundant on the California coast, but less common toward the north, being supplanted by numerous other forms. It reaches its optimum growth in localities where the surf is only moderately active. In such situations it attains its greatest height, not infrequently specimens attaining a height of $4.5 \mathrm{dm}$., but when on boulders exposed to a heavy surf, it remains much shorter, is more arborescent, the alae wearing away up to the last segment. The illustration on plate 3 is of the former state, and that on plate 2 is from an exposed situation at Fort Ross, California, presumably the type locality for the species. I have selected this specimen as the type because it shows the proliferating habit which seems to be the character of the specimen illustrated by Agardh (see plate 1, figure 1). There is considerable individual variation in the width of the segments. The dimensions given in the diagnosis cover a very large majority of individuals in a bed of plants, but oceasionally wider or narrower plants may be found. They fruit abundantly, only an. occasional segment remaining sterile to continue the growth and fruiting in the next season if the plant persists. Most of the segments fruit simultaneously, and the height of the fruiting season is in June and July; some receptacles may, however, be found at any season of the year, as is usually the case with all the species of the genus.

The specimens after desiccation readily yield a copious amount of mucilaginous substance on being revived, either with fresh or with salt water. It was hoped that the copious secretion of mucilage might be traced to the eaecostomata which are so abundant in this species, and that this definite function might be assigned to them, but it has not been possible to connect these structures with this function. 


\section{Fucus furcatus f. angustus f. nov.}

\section{Plate 4}

Frons angusta, caulescens, rigida, subcartilaginosa, 20-35 cm. alta, dichotoma, obscure olivaceo-brunnea, siccata atra; segmentis linearibus vel paululum cuneatis, $4-7 \mathrm{~mm}$. latis, apjeibus truncatis, costa evidenter percursa, caecostomatibus $125-175$ in quoquo $\mathrm{em}$. quadrato; receptaculis vulgo complanatis, interdum inflatis, distincte definitis, alte bifidis, 4-7 cm. longis, apicibus acutis vel acuminatis; conceptaculis numerosis confertim dispositis.

Growing in abundance on rock ledges in the upper third of the littoral belt. San Juan County, Washington, and the central coast of Oregon.

Type, Gardner, no. 2788 (Herb. Univ. Calif., no. 201188), Sunset Beach, near the mouth of Coos Bay, Oregon, May, 1914.

The only other definite locality in which this form has been detected is Cattle Point, at the south end of San Juan Island, Washington (Gardner, no. 2352g). This locality is particularly rich in forms of Fucus. There is an intermingling of the waters flowing among the islands to the north and east, which have a varied Fucus flora, with the waters from the Strait of Juan de Fuca and the Straits of Georgia, washing the shores of land to the west and north, which have a somewhat different Fucus flora. The shore of the south side of Cattle Point is exposed to a swiftly flowing eurrent and to the action of swells from the Pacific Ocean, through the Strait of Juan de Fuca. Around to the north side of the point the shores are affected but little by the action of the surf and tides.

Frucus furcatus $\mathrm{f}$. angustus seems closely related to $F$. inflatus $\mathrm{f}$. edentatus of Börgesen. I draw my conclusion after having compared our plants with a specimen of Börgesen's from the Faeröe Islands in the Herbarium of the University of California, no. 99176. I have represented this specimen on plate 20. Börgesen's specimen has a more pronounced midrib and the segments are more decidedly cuneate. The color is not so dark as the color of our specimen. The fronds are somewhat roughened and possess a large number of caecostomata, very similar to f. angustus. 


\title{
Fucus furcatus $f$. linearis $f$. nov.
}

\author{
Plate 5
}

Frons paullo caulescens, cartilaginosa, $30-35 \mathrm{~cm}$. alta, ramosissima dichotoma, obscure olivaceo-viridis, siccata atra; segmentis strictis, linearibus, 8-12 mm. latis, caecostomatibus $40-70$ in quoquo $\mathrm{cm}$. quadrato, siccatis inconspicuis; receptaculis numerosissimis distincte definitis, quam frondibus latioribus, integris vel bifidis, vulgo ovatis, $1.5-2 \mathrm{~cm}$. longis; conceptaculis numerosis, amplis.

Growing in quiet water on boulders in the lower littoral belt. Tracyton, Kitsap County, Washington.

Type, Gardner, no. 2206b (Herb. Univ. Calif., no. 201142), May, 1910.

This form is remarkable for the abundance of receptacles it produces on a single plant. Plate 5 was made from a portion of a plant that had approximately five hundred and fifty receptacles. It is also rather unusual that so many of the segments should fruit at the same time as is the case in this form. Not a single segment remained sterile in the above mentioned plant. This form does not seem to be abundant in the Puget Sound region.

\section{Fucus furcatus f. abbreviatus f. nov. \\ Plate 6}

Frondes cartilaginosae rigidae, asperae, 8-12 cm. altae, regulariter dichotomae, olivaceo-virides vel olivaceo-brunneae vel luteolae; segmentis cuneatis vel linearibus, $8-16 \mathrm{~mm}$. latis, apicibus truncatis, costa angusta evidente, caecostomatibus comparative amplis, siccatis prominentis, $60-80$ in quoquo $\mathrm{cm}$. quadrato ; receptaculis distincte definitis quam segmentis multo latioribus, $2-2.5 \mathrm{~cm}$. longis, complanatis vel muco inflatis, 1-2-furcatis, apicibus acuminatis; conceptaculis numerosis valde prominentibus.

Growing on boulders in the middle littoral belt. Islands of San Juan County and vicinity, Washington.

Type, Gardner no. 2347 (Herb. Univ. Calif., no. 201200), Waldron Island, San Juan County, Washington, July, 1910.

This form is fairly abundant in the moderately quiet waters among the islands of San Juan County, Washington, and extends into the upper Sound region. It varies considerably in size, both in length and in width of the fronds. Specimens 3 to $4 \mathrm{~cm}$. in height have been taken in full fruit, but these were depauperate forms, in the upper 
limit of the belt in which they grow. The striking features of this form are the short bunchy habit, the abundance of well developed receptacles appearing simultaneously, and the numerous large caecostomata making the fronds rough, particularly prominent on drying.

\section{Fucus furcatus f. cornutus f. nov.}

Plate 7

Frondes subcoriaceae, $20-30 \mathrm{~cm}$. altae, regulariter dichotomae, obscure olivaceo-virides vel obscure olivaceo-brunneae siccatae atrae; segmentis divergentibus, linearibus vel is angustioribus paullo cuneatis vel iis latioribus manifeste cuneatis, $5-6 \mathrm{~mm}$. latis, apicibus acuminatis, truncatis, costa distincte exposita, prominente, superne paululum evanida, alis angustis, caecostomatibus sparsissimis, parvis, 10-20 in quoquo $\mathrm{cm}$. quadrato; receptaculis distincte definitis, valde variabilibus, complanatis vel inflatis, vulgo quam segmentis multo latioribus, integris, vel bifurcatis, $2-4 \mathrm{~cm}$. longis, obtusis vel acuminatus, apicibus vulgo a laterale reflexis; conceptaculis non numerosis, inconspicuis.

Growing on rocks in the middle and lower littoral belts. From Yakutat Bay, Alaska, to Victoria, British Columbia.

Type, Gardner, no. 3993a (Herb. Univ. Calif., no. 201193), Sitka, Alaska, July, 1917.

Fucus evanescens f. cornutus, Saunders, Alg. Harriman Exp., 1901, p. 432, pl.62, fig. 2; Collins, Mar. Alg. Vancouver Isl., 1913, p. 111; Collins, Holden and Setchell, Phye. Bor.-Amer. (Exsice.), no. 927.

I have not seen the Saunders' specimen, but have based my judgment upon his description and figure quoted above, which seem to agree very well with my specimen from Sitka. He states that some of the receptacles are up to $7 \mathrm{~cm}$. long, being much longer than any which I have seen.

The narrow fronds with prominent midribs and the very dark color make this form close to certain narrow forms of edentatus, but the absence of cryptostomata and the small caecostomata relate it to the furcatus group. It has the least number of caecostomata of all the forms with which I am familiar, certain specimens being nearly free from them. In this character the form approaches very closely to the edentatus group. 


\section{Fucus furcatus $f$. nigricans f. nov.}

\section{Plate 8}

Frondes comparative fragiles, tenues, membranaceae, $35-45 \mathrm{~cm}$. altae, regulariter dichotomae, obscure olivaceo-viridis, siccatae atrae, angulis latis paulum rotundatisque; segmentis inferne cuncatis superne linearibus, ad segmenta terminalia 3-4 infra apicibus ad costam diminuatis, ad singulem axillam diminuatis, usque ad 18-24 mm. latis; costa angusta distincta, percursa, alis tenuibus, caecostomatibus 70-80 in quoquo cm. quadrato, parvis, obseuris; receptaculis $2.5-3.5 \mathrm{~cm}$. longis, complanatis vel inflatis, integris vel bifidis, manifeste definitis, apicibus plerumque acutis reflexisque.

Growing on boulders and rock ledges in the middle of the littoral belt. Cattle Point, south end of San Juan Island, Washington.

Type Gardner, no. 2352h (Herb. Univ. Calif., no. 201195), July, 1910.

Plate 8 represents the type specimen of this form. Comparison of this plate with a representation of the type specimen of Kjellman's $F$. evanescens f. cornutus on plate 55 shows the much more pronounced cornute habit of the receptacles than Kjellman's plant possesses. In this habit, forma nigricans is closely akin to forma cornutus, but differs from it in the following characters: thinner fronds which are more cartilaginous, darker color, black on drying, in having widely divergent segments and in having an abundance of caecostomata.

\section{Fucus furcatus f. elongatus f. nov.}

\section{Plate 9}

Frons sparse ramosa, distincte arborescens, parum foliacea, $3-5 \mathrm{dm}$. alta, regulariter dichotoma, angulis latis rotundatisque, obscure olivaceo-viridis, siccata obscure olivaceo-brunnea, segmentis longis, 10-18 mm. latis, cuneatis, segmento terminale saepe ovato, puncto crescente parum depresso, costa angusta evidente, vulgo superne luteola, alis inferne attritis, ad $4-5$ segmenta terminalia persistentibus, caecostomatibus variabilibus vulgo numerosis, usque ad 450 in quoquo cm. quadrato, eryptostomatibus paucis, sparsis, paraphysum fasces longos exsertes gerentibus; receptaculis obscure brunneis vel luteolis, aut complanatis aut multo inflatis, distincte definitis, integris emarginatis vel bifidis, obtusis vel acutis, $3-5 \mathrm{~cm}$. longis; conceptaculis nec prominentibus neque numerosis.

Growing on boulders in the lower littoral belt in localities exposed to the surf. South end of San Juan Island, Washington, and Sunset Beach, near the mouth of Coos Bay, Oregon.

Type, Gardner, no. 2793 (Herb. Univ. Calif., no. 201178), Sunset Beach, Oregon, May, 1914. 
This form is intermediate, in several of its characters, between $F$. furcatus f. typicus and $F$. furcatus f. luxurians. On drying it is smoother than either of the above mentioned forms, the caecostomata not standing out so prominently.

The type (plate 9) was collected in May, and, although fruiting abundantly, may possibly be immature, judging from the number of blunt receptacles. No. 2352b, Gardner, from San Juan Island, was collected in July and the receptacles have apparently reached their maximum size. The plants from this locality are scarcely typical in every respect. The fronds average slightly narrower and the caecostomata are much fewer, but it seems too close to be segregated under a form name. Gardner, no. 1973 (Herb. Univ. Calif., no. 132743, and in Collins, Holden, and Setchell, Phye. Bor.-Amer. (Exsice.), no. CX, sub $F$. evanescens $\mathrm{f}$. macrocephalus $\mathrm{Kjellm}$.) is typical of $\mathrm{f}$, elongatus in color, character of branching, having mostly wide and usually rounded angles, character of segments and receptacles, but varies from the type in having very few caecostomata. It is certainly quite different from Kjellman's $F$. evanescens f. macrocephalus in all of its important characters. Compare plate 9 with plate 46 , representing Kjellman's type.

\section{Fucus furcatus f. Iuxurians f. nov.}

\section{Plate 10}

Frons distincte caulescens, cartilaginosa, alis attritis, costa densa in complanatum stipitem transeunti, regulariter dichotoma, 4-5 dm. usque ad $9 \mathrm{dm}$. alta, obscure olivaceo-viridis vel olivaceo-brunnea, costa receptaculisque luteolis, disco radicali magno firmoque; segmentis variabilibus late cuneatis vel fere linearibus, saepe ad costam oblique fissentibus, $1.5-3 \mathrm{~cm}$. latis, terminale saepe latiori rotundatoque, caecostomatibus numerosissimis, $300-350$ in quoquo $\mathrm{cm}$. quadrato, cryptostomatibus sparsis, paraphysum fasces longe exsertes gerentibus; receptaculis manifeste definitis, 4-6 cm. longis, complanatis vel acuminatis; conceptaculis numerosissimis.

Growing on boulders and rock ledges in the middle of the littoral belt. Northern and central California.

Type, Gardner, no. 4327 (Herb. Univ. Calif., no. 201220), Moss Beach, San Mateo County, California, July, 1918.

Plate 10 represents a plant of this form in mature fruit, producing receptacles for the first time. The receptacles in this specimen are all complanate, a condition which prevails very commonly, but in certain localities the receptacles are tumid and mucilaginous. 
Forma luxurians is closely related to forma typicus. The two forms often grow intermingled, but may readily be distinguished by differences in size and color, forma luxurians being much more robust, and of a lighter brownish or yellowish color in the upper parts, particularly the receptacles. The southern limit of the form, as of all forms of Fucus so far as is at present known, is Oil Port, San Luis Obispo County, California. The northern limit has not yet been determined, but it probably extends as far north as Cape Flattery, Washington, where there is an intermingling of several forms whose limits have not yet been determined. It merges into forma elongatis from Coos Bay, Oregon, which I have segregated, as is illustrated on plate 9.

The plants persist for several years, are in fullest fruit in early summer, although some receptacles may be found at any season of the year. Always a portion of the segments resulting from forking remains sterile. These continue to grow and branch, forming segments for the next year's receptacles, while the other segments fruit and disintegrate, leaving the midrib of the segment as a pointed projection. The plants do not seem to proliferate. Many of the alae split obliquely to the midrib, giving them a serrate appearance. Plants growing at Pacific Grove, California, which I have referred to this form, are subject to this habit quite generally. I have noticed also that in this locality the plants have a decided tendency, toward the end of the growing season of the receptacles, to establish several meristematic regions on the ends of the receptacles, some of which produce quite prominent and pointed projections with a tendency to becoming vegetative, as many as ten having been observed on a single receptacle with a common wide base.

\section{Fucus furcatus f. reflexus f. nov.}

Plates 11, 11a, and 12

Frondes foliaceae, subcartilaginosae, $30-45 \mathrm{~cm}$. altae, regulariter dichotomae, obscure olivaceo-virides vel obscure olivaceo-castaneae, angulis saepissime latissimis rotundatisque; segmentis inferne cuneatis, terminalia saepe obovatis, $8-25 \mathrm{~mm}$. latis, apicibus rotundatis, puncto crescente paululum depresso, costa angusta distincta, superne paullo evanida, caecostomatibus numero variabilibus, 50-150 in quoquo $\mathrm{cm}$. quadrato; receptaculis manifeste definitis, substipitatis, complanatis, ellipsoideis, integris vel bifidis, late patentibus; conceptaculis parvis numerosisque.

Growing on boulders in the lower littoral belt. Point Defiance, Tacoma, Washington.

Type, Gardner, no. 2190 (Herb. Univ. Calif., no. 201145), May, 1910. 
The consistency of this form is somewhat like that of the evanescens group, the tissues being more delicate and soft than those of the typical furcatus forms. I have placed it in the furcatus group on account of the color, dark olive green to dark olive brown; and the presence of cryptostomata in abundance.

Many of the terminal segments are very broadly ovate, almost stipitate, on account of the narrowing of their bases, producing broad rounded angles between the segments (plate 12). The growing points differ from those of all other forms observed on our coast, the apices of the segments being rounded and smooth, but with slight ineonspicuous slits to indicate the position of the growing point.

The receptacles, particularly when young, have the pronounced and distinguishing character of spreading very widely from each other at their bases, in some instances standing at right angles, or even more, to each other. Many segments have the eharacter of reducing their width at each forking, the terminal segments forming the stipelike portion bearing the much wider receptacles.

\section{Fucus furcatus f. rigidus f. nov.}

Plate 13

Frondes robustae, rigidae, cartilaginosae, $30-45 \mathrm{~cm}$. altae, dichotomae vel subsecundae, obscure olivaceo- virides, siccatae atrae, costa et receptaculis subtus olivaceo-viridibus, supra olivaceo-brunneae vel

- luteolis, angulis saepissime rotundatis; segmentis linearibus vel paullo cuneatis, strictis, $1.5-3 \mathrm{~cm}$. latis, apicibus truncatis, costa prominente, caecostomatibus $60-100$ in quoquo $\mathrm{cm}$. quadrato; reeptaculis indistincte definitis, complanatis, linearibus, apicibus acuminatis, 2-3furcatis, $12-20 \mathrm{~mm}$. latis, $5-8 \mathrm{~cm}$. longis; conceptaculis magnis partem cuneatem e receptaculo costam decurrentem vestientibus.

Growing on boulders in the lower littoral belt. Port Townsend and west coast of Whidbey Island, Washington.

Type, Gardner, no. 1982 (Herb. Univ. Calif., no. 201138), Port Townsend, Washington, July, 1908. Gardner, no. $2352 a$ (Herb. Univ. Calif., no. 201214), from San Juan Island, seems also to belong here. Most of the specimens of this latter collection have shorter receptacles with wider base and with most attenuate and divergent apices.

According to my conception of this form, its phylogenetic position is between forma latifrons and forma luxurians. From the former it differs in having a more rigid cartilaginous structure, in having narrower and more strict segments, and in having longer and narrower receptacles. From the latter it differs in having more strict and more nearly linear segments and longer and narrower receptacles. 
Fucus furcatus f. latifrons f. nov.

Plate 14

Frons distincte foliacea, contorta, comparative tenuis, $25-35 \mathrm{~cm}$. longa, inferne obseure olivaceo-brunnea, superne pallide brunnea, siceata atra, dichotoma, angulis vulgo acutis; segmentis cuneatis, segmentis terminalibus valgo rotundatis, $2-3.5 \mathrm{~cm}$. latis, costa inferne prominente, superne distincte diminuante, eaecostomatibus $40-80$ in quoquo $\mathrm{cm}$. quadrato; receptaculis indistincte definitis, complanatis, 2-3-fureatis, vulgo acutis; conceptaculis amplis, vulgo costam descendentibus, segmenti partem cuneatam vestientibus.

Growing on rocks in the middle and lower littoral belts. Channel Rocks, near Fort Ward, west of Seattle, Washington.

Type, Gardner, no. 1972 (Herb. Univ. Calif,, no. 201221), August, 1908. Fucus evanescens f. pergrandis, Collins, Holden, and Setchell, Phyc. Bor.-Amer. (Exsice.), no. XCI.

In width of fronds, this form of $F$. furcatus overlaps or merges into forms of $F$. evanescens, e.g., forma magnificus. I am placing it under furcatus on account of the dark olive green color, more or less cartilaginous consistency, and particularly on account of the abundance of eaecostomata.

It is closely related to $F$. furcatus $\mathrm{f}$. rigidus, but the fronds are more foliaceous, the receptacles are wider and shorter and the caecostomata are less abundant.

Fucus furcatus f. contortus f. nov.

Plate 15

Frons 20-30 cm. alta, inferne caulescens, superne foliacea, robusta, cartilaginosa, valde contorta, dichotoma vel subdichotoma, inferne olivaceo-viridis, superne luteola, siccata obscure olivaceo-castanea; segmentis inferne cuneatis marginibus crispatis, superne linearibus, supra axillas diminuatis, $2-2.5 \mathrm{~cm}$. latis, apicibus rotundatis, depressione crescente parva, costa prominente, caecostomatibus 250-300 in quoquo $\mathrm{cm}$. quadrato, siceatis minute papillosis; receptaculis complanatis, 4-7 cm. longis, indistincte definitis.

Growing in quiet water on boulders in the lower littoral belt. Near Bellingham, Washington.

Type, Gardner, no. 2335 (Herb. Univ. Calif., no. 201189), July, 1910.

A dried fragment of a plant of this form is shown on plate 15 . The form seems to be quite distinct from all others. Its color, its rigid, cartilaginous consistency, its relatively wide fronds, its large 
number of caecostomata, its contorted and crisped habit of growth are characters not found combined in any other known form. The plants were found growing in great profusion, in good vegetative condition in midsummer. The fruiting season apparently is in the winter, as only a few well developed receptacles could be found.

\section{Fucus furcatus $f$. variabilis f. nov.}

Plates 16 and 17

Frons caulescens, superne foliacea, 25-40 cm. alta, subcartilaginosa, dichotoma vel partim subsecunda, obscure olivaceo-viridis vel olivaceobrunnea, siccata atra, costa et receptaculis luteolis; segmentis linearibus vel paullo euneatis, $2-3.5 \mathrm{~cm}$. latis, plerumque supra axillas in latere diminuatis, costa vale exposita, percursa, caecostomatibus in numero variabilibus, paucis usque ad 75 in quoquo em. quadrato; receptaculis forma et magnitudine variabilibus, manifeste definitis, inflatus et mucosis vel complanatis, integris obtusisque vel $2-3$-furcatis acuminatisque.

Growing on rock ledges in quiet bays in the middle of the littoral belt. Sitka, Alaska.

Type, Gardner, no. 3993 (Herb. Univ. Calif., no. 201219), July, 1917.

A close relationship seems to exist between this form of $F$. furcatus and $F$. evanescens $f$. magnificus. The color, caecostomata characters, and the rigid, more or less cartilaginous consistency of the fronds are characters that belong to the furcatus group. The width of segments and particularly the fruiting habit (see under $F$. evanescens forma magnificus) are very similar to those of that form. The caecostomata vary much in number. In some specimens they are practically absent, while in others there may be seventy-five or perhaps more to the square centimeter. They are mostly large, deep-seated and inconspicuous on drying, except by transmitted light. Specimens with but a few caecostomata usually have a few small cryptostomata.

\section{Fucus nitens sp. nov.}

Plates 18 and 19

Frondes paululum flaceidae, coriaceae, $30-40 \mathrm{~cm}$. altae, regulariter dichotomae, obscure brunneae vel luteolae, in sicco valde brunneae; segmentis strictis, 9-18 mm. latis, levibus nitidisque, cuneatis, terminalibus latioribus, paullo ovatis, truncatis, puncto erescente parum depresso, costa paullo prominente, cryptostomatibus nullis vel sparsissimis; receptaculis luteolis, juvenibus complanatis, saepe demum tumidis, 2-3-furcatis, interdum usque ad $10 \mathrm{~cm}$. longis; conceptaculis magnis. 
Growing on boulders and rock ledges. San Francisco Bay, California.

Type, Gardner, no. 2165 (Herb. Univ. Calif,, no. 201150), Sausalito, California.

This relatively small group of Fucus plants, although very much circumseribed in its distribution, seems so distinctly marked off in its combination of characters from other species, particularly from those in the southern portion of the range covered in this paper, that it is worthy of specific rank. The combination of characters that distinguish this species consists of the following: relatively long and narrow, smooth and glossy fronds, strict, even overlapping habit of the terminal and subterminal segments, the dark brown color with yellowish receptacles at maturity, absence of caecostomata, and the cryptostomata, when present, are inconspicuous. Its affinities with F. edentatus may possibly be traced, but they seem too remote to merit much serious consideration. The somewhat coriaceous consistency of the fronds suggests relationship in that particular with certain forms of evanescens, but on the whole it inclines more, in its consistency, to the cartilaginous consistency of $F$. furcatus, under which $I$ have considered placing it. I have observed this species with considerable care throughout all seasons of the year for the last twenty years. In its typical habitat it seems thoroughly fixed as a distinct entity.

The chief association of plants extends along the rocky shore from the harbor at Sausalito to Point Cavallo, a distance of about two miles. There are a few smaller groups at other points in the Bay, but in all of these localities the waters are more quiet than along the shores of the Golden Gate out to the Pacific Ocean. In the localities where they are found they are never intermixed with any forms of $F$. furcatus, the only other known species on the California coast. No plants of $F$. nitens have ever been found growing on either side of the Golden Gate for some distance inside of the entrance. From Point Cavallo to some distance west of Lime Point, an interesting association exists for which I have no way of accounting, except by hybridization between these two species. A variety of intermediates exist. There are yellowish brown plants with inflated, yellowish, bi-, tri-furcate receptacles like those in the quiet waters of the Bay, but filled with hundreds of small caecostomata characteristic of $F$. furcatus; and there are plants with flat receptacles and olive green, cartilaginous fronds but which are smooth and glossy and wholly lacking in caecostomata, characters belonging to $F$. nitens. These and other combina- 
tions of modifications lead me to believe that these two species must hybridize in this locality.

Both species are synoicous and hence it would be very difficult to carry out definite hybridizing experiments.

\section{Fucus edentatus De la Pyl.}

Plate 60, figure 1

"F. fronde longa valida, lineari dichotoma, integerrima, nervo percurrente plerumque vix tumido vel obsoleto; conceptaculis terminalibus, planis, simplicibus; lineari-lanceolatis; parum acutis, vulgo geminatis aut basi connatis, fronde non latioribus."

De la Pylaie, Flor. Terre-Neuve, 1829, p. 84.

Fronds usually narrow, more or less flaccid, regularly dichotomous, olive green to olive brown or yellowish, usually very black on drying; segments mostly decidedly linear, at times cuneate, midrib distinct, percurrent, cryptostomata few or none, receptacles mostly narrow, linear-lanceolate, acuminate, inflated or complanate.

Growing in the middle and upper littoral belts. From Sitka, Alaska, to Coos Bay, Oregon.

For a discussion of this species major see page 10.

Fucus edentatus f. hesperius f. nov.

Plate 21

Frondes arborescentes, $30-40 \mathrm{~cm}$. altae, angustae, coriaceae, dichotomae, obscure olivaceo-virides, in sicco atrae, stipite cylindrato; segmentis strictis, linearibus, $5-10 \mathrm{~mm}$. latis, apicibus truncatis et valde expositis, prominentibus, costis percursis; cryptostomatibus nullis vel summe infrequentibus, receptaculis plerumque complanatis vel partim valde inflatis, 2-3-furcatis, linearibus, $3-4.5 \mathrm{~cm}$. longis apicibus acutis ; conceptaculis numerosis.

Growing on rock ledges exposed to the action of the surf, in the upper third of the littoral belt. Cape Arago, at the entrance to Coos Bay, Oregon.

Type, Gardner, no. 2653 (Herb. Univ. Calif., no. 201159), May, 1914.

This form grew in abundance in company with $F$. furcatus $\mathrm{f}$. angustus. The two groups of plants were, however, in slightly different altitudes in the belt, and were not indiscriminately intermixed. When the two sets of plants are dried, they are easily distinguishable by the smoothness of the segments, forma hesperius being smooth and usually shining, while forma angustus is rough, due to caecostomata, and is of a duller color. 
Forma hesperius seems closely related to or is at least very similar to a narrow, smooth, dark colored form that grows on the Atlantic coast of the United States, which has been referred to different species by different authors. There is a good specimen of it contributed by Howe, under no. 150, to the Herbarium of the University of California, no. 77184, labelled $F$. edentatus. The specimen in Professor Setchell's copy of Farlow, Anderson, and Eaton's Algae Exsiceatae Americae Borealis, no. 108, is almost identical with Howe's specimen, but is referred to $F$. furcatus. I have examined no. 119 of Hauck and Richter's Phykotheka Universalis, labeled Fucus edentatus De la Pyl. and contributed by Collins. from Marblehead, Massachusetts. This specimen seems to be identical with the two above mentioned. It is my opinion that all three collections should be referred to $F$. edentatus De la Pyl., and, judging from the figure and description of the type as quoted above, very clearly represent the typical form of the species. None of the Atlantic specimens referred to above have caecostomata.

\section{Fucus edentatus $f$. divergens $f$. nov.}

\section{Plate 22}

Frondes coriaceae, leves nitidaeque, $28-38 \mathrm{~cm}$. altae, regulariter dichotomae, obscure olivaceo-virides, siccatae atrae; segmentis divergentibus 7-11 mm., usque ad $15 \mathrm{~mm}$. latis, inferne cuneatis, superne linearibus, supra axillas paullo diminuatis, terminalibus truncatis, puncto erescente inconspicuo, costa manifeste distincta, percursa, cryptostomatibus et caecostomatibus nullis vel sparsissimis; receptaculis 3-6 $\mathrm{cm}$. usque ad $12 \mathrm{~cm}$. longis, manifeste definitis, quam segmentis multo latioribus, integris vel 1-2-furcatis, vulgo late divergentibus, apicibus acuminatis vel acutis; conceptaculis numerosis prominentibusque.

Growing on rock ledges in the lower littoral belt. Kanaka Bay, San Juan Island, Washington.

Type, Gardner, no. 2338 (Herb. Univ. Calif,, no. 201173), July, 1910.

This form of edentatus is closely related to forma hesperius. The fronds average somewhat wider, more robust, the angles between the segments are very much wider and more rounded, and the receptacles mostly deeply bifurcate or single, widely diverging. The average width of the segments is about $10 \mathrm{~mm}$., but a few specimens were found with extremely narrow segments, about $3 \mathrm{~mm}$. These were profusely branched, with wide angles, and small diverging receptacles. Also a few specimens were found with the characters of the form, but were $15 \mathrm{~mm}$. wide. These few specimens I have considered as the extremes in individual variation in this particular character. 
Fucus edentatus $f$. costatus f. nov.

Plates 23 and 24

Frons tenuis, subcoriacea, $15-25 \mathrm{~cm}$. alta, regulariter dichotoma, luteola; segmentis manifeste linearibus, comparative longis, supra axillas in latere diminuatis, usque ad $5-8 \mathrm{~mm}$. latis, terminalibus 2-4 mm. latis, costa valde exposita, percursa, alis angustis et membranaceis, cryptostomatibus sparsis, prominentibus; receptaculis manifeste definitis, integris vel vulgo bifidis, $20-35 \mathrm{~cm}$. longis, apicibus acutis; conceptaculis paullo numerosis conspicuisque.

Growing on rocks in the lower third of the littoral belt. Lower Puget Sound region, Washington.

Type, Gardner, no. 2333 (Herb. Univ. Calif., no. 201199), East Sound, Oreas Island, Washington, July, 1910.

Fucus evanescens f. angustus, Gardner, no. 694, and in Collins, Holden, and Setehell, Phyc. Bor.-Amer. (Exsice.), no. 926 (cf. Setchell and Gardner, Alg. N.W. Amer., 1903, p. 284). This form does not seem to be very generally distributed in the Puget Sound region, having been observed in only a few localities.

The plants distributed in the Phycotheca Boreali-Americana as no. 926 were from the type locality, but were taken from the upper limit of the belt of distribution when the tide was well in. They are considerably battered and worn away, and thus cannot be said to be in typical condition. Plate 23 represents a young plant, the type, mostly in typical vegetative condition. Plate 24 represents two plants, showing the extremes in variation in the width of the fronds. Specimens as narrow as the narrower sterile one on the plate are rare, and at some future time may have to be considered as distinct. The illustrations were all made from dried material.

This form resembles closely $F$. evanescens f. angustus Kjellm. in width of fronds, and was so referred as is cited above. Subsequent to the above publications, material of that species, collected and determined by Kjellman on the Vega expedition, has been received at the Herbarium of the University of California (no. 132699). The lack of a prominent percurrent midrib, almost complete absence of cryptostomata, and especially the very small receptacles of Kjellman's material, point out unmistakably that our plant is of a different lineage. 


\section{Fucus edentatus f. acutus f. nov.}

Plate 25

Frondes 9-15 cm. altae, disco comparative lato planoque oriundae, dichotomae. angulis acutis. olivaceo-virides. siccatae atrae; segmentis linearibus, $3-4 \mathrm{~mm}$. latis, apicibus truncatis, costa valde prominente, pereurrente, alis comparative angustis, persistentibus, eryptostomatibus sparsis; receptaculis singulis ant valde bifurcatis, ad finibus quibusque attenuatis, $2-2.5 \mathrm{~cm}$. longis.

Growing on sandstone in the middle littoral belt. Bellingham (Fairhaven), Washington.

Type, Gardner, no. 189 (Herb. Univ. Calif., no. 201137).

Fucus inflatus $f$. linearis Setehell and Gardner, Alg. N. W. Amer., 1903, p. 280.

The very dark color on drying, the absence of caecostomata, and the sparseness of cryptostomata in this form seem amply sufficient to ally it with the edentatus group rather than with the seemingly more imperfectly defined group inflatus. The linear arrangement of the cryptostomata in two rows along the prominent midrib and the relatively small. pointed receptacles distinguish it from all other forms of edentatus.

\section{Fucus edentatus f. divaricatus f. nov.}

\section{Plate 26}

Frondes fragiles, plerumque $12-22 \mathrm{~cm}$, rariore usque ad $32 \mathrm{~cm}$. altae, regulariter dichotomae, angulis latis, stipite et ramis infernis fere teretis, saturate olivaceo-brunneae, receptaculis plerumque lutescentibus, segmentis anguste linearibus, latitudine ad furcas quasque parvis diminuatis, terminalibus acutis, 2-5 mm. latis, costa usque ad apices valde evoluta, alis fere deuntibus, cryptostomatibus paucis et inaequaliter distributis; receptaculis definite delimitatis, subulatis aut leviter complanatis, $2.5-4.5 \mathrm{~cm}$. longis, plerumque simplicibus aut valde furcatis; conceptaculis conspicuis.

Growing on ledges of sandstone in the lower littoral belt. Bellingham, Washington, Comox and Ucluelet, Vancouver Island, British Columbia.

Type, Gardner, no. 2336a (Herb. Univ. Calif., no. 201198), Bellingham, Washington, July, 1910.

Fucus inflatus f. filiformis, Setchell and Gardner, Alg. N. W. Amer., 1903, p. 281; Collins, Mar. Alg. Vancouver Isl., 1913, p. 111.

Since collecting this form at "Fairhaven," a town later incorporated with Bellingham, Washington, I have had an opportunity to 
study much more extensively in the same general locality. As reported in Setchell and Gardner (loc. cit.), it was found growing on sand rocks. It is quite common on the sand rock ledges of that vicinity, but I have learned that its normal habitat is farther down in the littoral belt than was first reported. There were but a few plants growing in the first locality mentioned, on a ledge in the upper littoral belt, but in a shaded location. The majority of the specimens were very much dwarfed. The average height in their normal habitat is about $16 \mathrm{~cm}$, although some specimens were found up to $32 \mathrm{~cm}$. high. Gardner, no. $2336 a$, plate 26 , represents a fruiting plant of medium height from this collection.

\section{Fucus membranaceus sp. nov.}

Frondes magnitudine variabiles parvae vel usque ad $4 \mathrm{dm}$. altae, manifeste membranaceae, obseure olivaceo-brunneae vel superne luteolae; segmentis linearibus vel paullo cuneatis, strictis, alis membranaceis, costa comparative parva distincta et percursa, cryptostomatibus sparsis, plerumque ad segmenta terminalia et subterminalia dispositis, comparative parvis in sicco papillosis, receptaculis vulgo complanatis, partim inflatis, bifidis acuminatisque.

Growing in the littoral belt. From the Bering Sea to Puget Sound, Washington.

For a discussion of this species major see page 11.

Fucus membranaceus f. abbreviatus f. nov.

Plate 27

Frondes breves, membranaceae, flabelliformes, decomposite dichotomo ramosissimae, $8-14 \mathrm{~cm}$. altae; segmentis strictis, anguste cuneatis vel sublinearibus, $5-9 \mathrm{~mm}$. latis, apice truncatis, costa parum prominente paululum evanescente, alis tenuibus cryptostomatibus in segmentis terminalibus $20-40$ in quoque $\mathrm{cm}$. quadrato, ad partem frondis inferiorem paucis, parvis siccatis evidentioribus; receptaculis bifidis, plerumque muco inflatis, apice acuminatis aut truncatis, paullo divaricatis distincte definitis; conceptaculis numerosis, prominentibus.

Growing on rock ledges exposed to heavy surf, in the upper limit of the littoral belt. Sitka, Alaska.

Type, Gardner, no. 3995 (Herb. Univ. Calif., no. 201192), July, 1917.

Forma abbreviatus grew on the same islet on which forma acuminatus was found growing, but mostly higher up, some specimens were even above mean high-tide level. It differs from forma acuminatus 
principally in having shorter fronds, relatively much broader and shorter receptacles, fewer cryptostomata, and it is less mucilaginous. It seems closely akin to J. Agardh's Fucus bursigerus from Spitzbergen, but it is more robust, and much more profusely branched than his description and figure eall for (cf. J. Agardh, Spets. Alg. Till., 1868 , pp. 41,42, pl. 3). I have seen the specimen of Kjellman's $F$. evanescens $\mathrm{f}$. bursigera, also collected at Spitzbergen. The plants of Agardh and of Kjellman are undoubtedly of the same lineage, and they are probably allied more closely to the evanescens lineage than to any other. The Sitka plants under consideration, on the whole, and particularly on account of size and consistency, seem closer to the membranaceus group than to the evanescens group. The two groups certainly overlap through these two forms.

\section{Fucus membranaceus f. acuminatus f. nov.}

Plate 28

Frons caulescens, $12-20 \mathrm{~cm}$. alta, decomposite dichotoma, ramossima, brunnea aut folva; segmentis paullo cuneatis interdum linearibus, 4-9 $\mathrm{mm}$. latis, truncatis, costa in partem inferiorem distincta, infra receptaculis diminuatis, alis tenuibus membranaceis, cryptostomatibus paucis vel 50-60 in quoquo $\mathrm{cm}$. quadrato, saepissime infra receptaculis ad segmenta, ad partes vetustas deficientibus, minimis, siceatis evidentioribus; receptaculis numerosis, regulariter et profunde furcatis vel interdum unicis, saepissime complanatis, angustis, acutis, 2-3 cm. longis; conceptaculis numerosis.

Growing on rock ledges exposed to heavy surf, in the upper littoral belt. Sitka, Alaska.

Type, Gardner, no. 3995 (Herb. Univ. Calif., no. 201177), July, 1917.

This form was encountered but once. It was growing in abundance on a small rocky island in front of the Sitka harbor. It grew well up in the littoral belt, exposed to the heavy action of the surf. The plants growing in the most exposed places are quite arborescent in character, the alae wearing away up to the last two or three segments, leaving the much thickened midrib. In depressions and less exposed situations, the alae were usually wider and remained on the fronds longer. The plants in this group become exceedingly mucilaginous on being soaked out after a thorough drying. 


\section{Fucus membranaceus f. obtusus f. nov.}

Plate 29

Frons gracilis, plus minus caulescens, membranacea, $30-40 \mathrm{~cm}$. alta, dichotoma, olivaceo-viridis vel castanea, siceata obseure brunnea; segmentis strictis, linearibus val parum cuneatis, comparative longis, 10-16 mm. latis, costa percursa, alis tenuibus, eryptostomatibus et caecostomatibus numero paene aequalibus, $30-40$ in quoquo $\mathrm{cm}$. quadrato, parvis, siccatis papillosis; receptaculis definitis, multo inflatis, plerumque singularibus, partim bifidis, $2.5-4 \mathrm{~cm}$. longis, $1-1.5 \mathrm{~cm}$. latis, truncatis, luteolis; conceptaculis plus minus numerosis, eomparative parvis, non protrudentibus.

Growing on rocks in the middle and lower littoral belts. Sitka, Alaska.

Type, Gardner, no. 2221 (Herb. Univ. Calif., no. 201155), June, 1910.

This form has characters linking together forma acuminatus and forma typicus of this species. It has the arborescent habit common to both forms, the width of the fronds is intermediate, and the receptacles are mostly simple and blunt, like neither form.

\section{Fucus membranaceus f. typicus f. nov.}

Plates 30 and 31

Frons caulescens, $28-40 \mathrm{~cm}$. alta, flaccida, membranacea, dichotoma, alis inferne attritis, costam comparative parvam, crassam cylindratam relinquentibus luteolis; segmentis anguste cuneatis vel linearibus, 10-18 mm. latis, puncto crescente in depressione parva lunata disposito, costa parum exposita, alis tenuibus, cryptostomatibus parvis, $20-25$ in quoquo cm. quadrato, siceatis evidentibus, plerumque ad segmenta terminalia et subterminalia dispositis, receptaculis comparative amplis, distincte definitis, plerumque inflatis, bifidis, apicibus longe acuminatis; conceptaculis parum numerosis, comparative parvis, ob colorem castaneum conspicuis.

Growing on rock ledges and boulders in the middle of the littoral belt. Sitka, Alaska.

Type, Gardner, no. 3996 (Herb. Univ. Calif., no. 201213), July, 1917.

I have taken this form to be the typical form of the species major, more or less arbitrarily, it is true, but largely because it is a medium among the known members of the group. I know of no way that one could tell that it has given rise to all or to any of the other forms, or that any one of the other forms has given rise to it, in fact whence any of the forms came. The form was sparsely interspersed in groups among the multiplicity of forms growing in the vicinity of Sitka. It 
may be readily recognized by its light yellowish color, its mostly inflated receptacles, and by its moderately narrow, long, membranaceous fronds.

\section{Fucus membranaceus f. limitatus f. nov \\ Plate 32}

Frondes manifeste membranaceae, 22-32 cm. altae, dichotomae, pallide luteolae, siccatae obscure brwneae, stipite et disco radicali fragilibus; segmentis strictis, vulgo cuneatis, plerumque ad axillas latioribus, $12-20 \mathrm{~mm}$. latis, lobis terminalibus rotundatis, puncto erescente paullo depresso, costa non prominente, alis tenuibus, cryptostomatibus sparsissimis et non conspicuis; receptaculis vulgo inflatis, bifidis, apicibus acuminatis vulgo divergentibus magnitudine valde variabilibus, usque ad $5 \mathrm{~cm}$. longis, $2 \mathrm{~cm}$. latis; conceptaculis sparsis non prominentibus.

Growing on rocks, logs, etc, in sheltered localities in the upper third of the littoral belt. Point Defiance, Tacoma, Washington.

Type, Gardner, no. 2189 (Herb. Univ. Calif., no. 201160), May, 1910

It is not easy to delineate the distinctive characters of this form associating it with the membranaceus group, rather than with the evanescens group. In many specimens the midrib is quite indistinct. The cryptostomata characters are quite as much of the one group as of the other. I am placing it provisionally with the former group largely on account of the predominance of inflated receptacles, on the membranaceous character of the fronds, and on the color.

Two forms of Fucus were found growing at Point Defiance, representing an interesting case in distribution. Forma limitatus occupied for the most part the extreme upper portion of the littoral belt, and grew on logs and boulders. F. furcatus f. reflexus grew on boulders and oceupied the lower third, with an occasional plant of either form invading the central part.

\section{Fucus membranaceus f. latissimus f. nov.}

Plates 33 and 34

Frondes foliaceae, membranaceae, crispatae, dichotomae, $22-35 \mathrm{~cm}$. altae, inferne obscure olivo-virides, superne fulvae disco radicali parvo, stipite complanato; segmentis superne paululum ovatis, inferne angustioribus cuneatisque, subterminalibus $4-6 \mathrm{~cm}$. latis, costa comparative angusta percursa, alis tenuibus, membranaceis, saepe inflatis, marginibus undulatis apicibus rotundatis et levibus, puncto crescente inconspicuo, cryptostomatibus $15-20$ in quoquo $\mathrm{cm}$. quadrato, paraphyses multas protrusas producentibus, siccatis prominentibus; receptaculis sparsis, complanatis, indistincte definitis, basi latioribus, bi-tri-furcatis. 
Growing on boulders in the extreme lower littoral belt. Kadiak Island and Sitka, Alaska.

In June, 1910, I first observed this form growing in the harbor at Sitka, but at that time I was unable to obtain good fruiting specimens. On my second visit to the same place in July, 1917, I located a large bed containing thousands of plants growing along the extreme low-tide level, and I was able to procure a number of good fruiting specimens, although the summer season does not seem to be its best fruiting season. This form may be readily distinguished from all others by its width, being the widest form in the vicinity, its membranaceous alae, its very dark lower portion, and usually yellowish upper portion, and by its much crisped habit of growth. Some of the plants of this species collected by G. B. Rigg at Kadiak Island are the widest specimens of Fucus that have been reported, some of the fronds measuring over seven centimeters in width.

\section{Fucus evanescens Ag.}

Plate 1, figure 2

"Fronde supra medium costata lineari integerrima subdichotoma evesiculosa, receptaculis compressis."

"Ad Sachalien, Tilesius; ad Kamtschatka, Chamisso; unde specimina communicaverunt."

"Simillimus F. vesiculosa, sed diversus. Frons magis flabelliformis. Segmenta cuneiformia, brevia, poris tenuissimis sparsis pertusa. - Costa subobsoleta \& supra frondem parum elevata, ante apicem omnino evanida, ita ut frons superne sit enervis. Receptacula brevia, saepe bifida, compressa nec inflata; tuberculata, tuberculis sparsis fere ut in Fuco serrato, glomerulis in gelatina filamentosa immersis."

Agardh, Sp. Alg., vol, 1, part 1, 1820, pp. 92, 93.

Fronds moderately robust sometimes arborescent, usually decidedly coriaceous, dichotomous or in part subsecund, olive brown, to yellowish above; segments often quite foliaceous and erisped, in some, narrow, cuneate to linear, midrib more or less distinct, in some cases vanishing more or less in the terminal segments, eryptostomata few to many. scattered; receptacles very variable in shape and size, long and narrow to short and blunt, bi- tri-furcate.

Growing in the littoral and upper sublittoral belts. From Bering Sea to Coos Bay, Oregon.

In Icones Algarum Ineditae, "1821, XIII, Agardh repeats the first paragraph of the above quotation in explanation of table XIII, which illustrates this species, and adds, "Specimen delineatum, ad Kamtschatka lectum, dedit clarissimus Chamisso. Fig. 1. Planta magnitudine naturali." I have here reproduced this figure on plate $\mathbf{1}$, 
figure 2, reduced 0.3. As may be seen, the illustration measures about ten and a half centimeters long and the segments fourteen millimeters wide. There is no holdfast portion, and the illustration appears to be of only a part of a plant, hence the height of the whole plant cannot be determined. The receptacles are complanate and are comparatively short, conditions which are commonly met with in most forms of Fucus when beginning to fruit. The receptacles of the plant from which the illustration was made were thus probably immature. For a detailed discussion of this species major see page 11.

\section{Fucus evanescens f. nanus Kjellm.}

"F. evanescentis forma thallo circa 5 ctmr alto, 2-3 mm lato, subcoriaceo, irregulariter dichotomo, segmentis linearibus vel sublinearibus, vulgo elongatis, costa in partibus thalli superioribus saepius obsoleta, receptaculis (in speciminibus nostris parum evolutis) vel ovatis vel obovatis, dichotomis, interdum deorsum vix definitis. Exsiccatione non nigrescit."

"Green Harbour ad scopulos prope rivuli ostium jacentes in superiore aquae limite, ut sub refluxu maris denudaretur. Formas hane sum forma typica connectentes in Mosselbay inveni."

Kjellman, Om Spetsb. Thall,, II, 1877a, p. 4.

Fronds minute, $4-5 \mathrm{~cm}$. high, 2-5 cm. wide, without distinct stipe and usually without holdfast, branching very irregularly, considerably twisted, color variable, yellowish brown to olive green, fruiting sparsely; segments extremely variable in shape and size, midrib slightly developed below, usually vanishing above, cryptostomata few or absent; receptacles entire or bifid, ovate-ellipsoidal or with divergent, blunt, or acuminate apices.

Plate 37

Growing mostly on mud flats at extreme high-tide limit, or even considerably above, among various salt marsh plants, covered more or less by fresh water. Yakutat Bay, Alaska, to Puget Sound, Washington.

Rev. Albin Johnson, no. 5712 (Herb. Univ. Calif., no. 99121), Yakutat Bay, Alaska; Gardner, no. 2256 (Herb. Univ. Calif., no. 201154), Sitka, Alaska; T. C. Frye (Herb. Univ. Calif., no. 132931), Tokeland, Washington.

Kjellman (loc. cit.) ; De-Toni, Syll. Alg., 1895, p. 203; Setchell and Gardner, Alg. N.W. Amer., 1903, p. 285.

After considerable observation in several different localities, I have come to the conclusion that $f$. nanus cannot be considered as a distinct form of any one species, but is in reality composed of a mixture of dwarfed plants of whatever species or forms of species that happen to 
inhabit the region. These dwarfs are always found on mud flats, salt marshes, and quite commonly at the mouths of rivers and smaller streams where such mud flats and marshes may occur. At extreme high tides, frequently, a great abundance of plants, of whatever species of Fucus happens to be growing in the vicinity, are thrown up and lodge among other plants that grow there. The spores are shed and, being in a moist place, they germinate and persist for a longer or shorter time. The plants are always much gnarled and distorted, and rarely come to fruit. At the mouth of the Indian River at Sitka, Alaska, is a favorable place for the study of such dwarfed plants. There are many different forms of Fucus growing in the vicinity, and a great many plants are constantly being cast up on the gradually sloping flat at the mouth of the stream. There are enormous numbers of dwarfed plants in all possible stages of development and distortion. One can come to no other conclusion than that these are dwarfed plants, that they are the offspring of whatever plants may by chance be thrown up there, and that their identity can not be traced, growing as they do in such unusually abnormal environmental conditions.

Among these abnormal environmental conditions may be mentioned, first, inconstancy in the food supply due to frequent changes in the salinity of the water, resulting in great differences in the osmotic tension; second, great variation in the temperature-the fresh water from the river flows over them more or less, and its temperature is near the freezing point a large part of the year; third, variation in light intensity; and fourth, exposure to muddy water. Under such conditions it is rather a biological wonder that any forms of the genus persist at all, yet many small specimens produce seemingly viable spores.

All of our forms on the Pacifie coast are synoicous. This makes the matter of tracing the ancestry of dwarfs slightly more difficult than if dioicous forms were present, without resorting to the experimental method by cultures.

The study of these dwarfed forms of brown seaweeds has been pursued quite extensively by Baker (1912) and by Baker and Bohling (1916). They traced the ancestry of certain forms and produced dwarfs experimentally. Some of these forms they claim to be fixed entities. They did not, however, try the experiment of producing sporelings from the dwarfed forms and transplanting them to a normal habitat to ascertain if they reverted at once to the original form. 


\section{Fucus evanescens f. cuneatus f. nov.}

Plate 38

Frondes parvae, 5-10 cm. altae, membranaceae, regulariter dichotomae, olivaceo-brunneae, segmentis inferioribus distincte cuneatis, segmentis terminalibus fere linearibus, 4-8 mm. latis, apicibus truncatis, costa inconspicua, superne paululum evanida, cryptostomatibus paucis, inconspicuis; receptaculis complanatis vel interdum inflatis, alte bifidis. plerumque acuminatis, ob plantae magnitudinem comparative amplis; conceptaculis comparative amplis numerosisque.

Growing on sandstone in the upper littoral region. Near Empire, Coos Bay, Oregon.

Type, Gardner, no. 2785 (Herb. Univ. Calif., no. 201196), May, 1914.

One becomes somewhat exasperated in attempting to deal with such forms as the one above. Ordinarily it might be considered a depauperate form of some other well developed and characteristic form. There were several square rods of fruiting plants like those represented on plate 38 growing on very gently sloping sandstone near high-tide level. There were no other plants growing near, and there was seemingly no reason why, from the standpoint of anchorage, they should not grow much farther down in the littoral belt. The reduced size could not be due to superabundance of fresh water, for several much larger forms were found growing from three to six miles farther up the bay where the water is much less saline. Many plants have welldeveloped mature receptacles.

Its general characters seem to favor its being grouped with $F$. evanescens, although it will fit practically as well into the edentatus group. I am placing it with the former until more can be learned of its life history.

\section{Fucus evanescens f. ecostatus f. nov.}

Plate 39

Frondes submembranaceae, 12-18 $\mathrm{cm}$. altae, dichotomae vel subsecundae. luteolae, siccatae obscure brunneae, stipite et disco radicali fragilissimis; segmentis strictis, euneatis, 5-12 mm. latis, puncto crescente inconspicuo, costa indistincta, fere ad lobos terminales evanida, alis tenuibus membranaceisque, eryptostomatibus paucis et inconspicuis: receptaculis variabilibus, inflatis vel complanatis, saepissime angustis, bifidis, acuminatis; conceptaculis inconspicuis.

Growing on sandstone, wooden floats, ete., in the upper littoral belt. Coos Bay, Oregon. 
Type, Gardner, no. 2791 (Herb. Univ. Calif., no. 201217), May, 1914.

Forma ecostatus is quite abundant at various localities from the mouth of Coos Bay up to its headwaters where several streams of fresh water flow in. This form seems to be definitely fixed, and does not appear to grade into any of the forms that are found growing outside of the bay. More investigation, however, may show that it is only a depauperate form of some definite species; on the other hand, it may prove to be a distinct species. It varies considerably in size and width of the fronds. The receptacles, though mostly pointed, are at times wide and blunt; at least there are specimens growing in the same habitat which have the same general characters but differ only in the character of the receptacles, and in such cases the segments are generally wider. They are connected, however, by almost imperceptible gradations. The size of the plants may be somewhat influenced by the substratum, mostly wood and soft sandstone, neither of which is suited to holding plants for a very great length of time. They usually do not persist in such localities beyond a single fruiting period. If the vanishing of the midrib is to be considered as having any diagnostic value, this form eminently belongs with the evanescens group. The midrib in some specimens is scarcely discernible in any part of the frond, and in all it vanishes in the terminal segments.

\section{Fucus evanescens f. oregonensis f. nov.}

Plate 40

Frons distincte caulescens, 15-20 cm. alta, subcoriacea, inferne dichotoma, superne subsecunda, luteola; segmentis angustis, sublinearibus vel paululum cuneatis, 4-7 mm. latis, flaccidis, levibus, costa angusta inferne evidente, superne parum evanida, cryptostomatibus parvis, inconspicuis, $20-25$ in quoquo $\mathrm{cm}$. quadrato; receptaculis tumidis, distincte definitis, quam segmentis ea gerentibus multo latioribus, integris aut bifidis, late fusiformibus, apicibus; valde obtusis : conceptaculis paululum conspicuis.

Growing on floats, piles, stones, etc., in the middle and upper littoral belts. East side of Coos Bay, opposite North Bend, Oregon.

Type, Gardner, no. 2786 (Herb. Univ. Calif., no. 201197), May. 1914.

This form seems decidedly distinct from all other forms previously described. Judging from its size, color, character of the midrib and its general consistency, its nearest relatives are to be found in the evanescens group, and close to forma flabellatus of this paper. The plants 
are smaller, segments narrower and regularly dichotomous instead of subsecund, and the receptacles are shorter and blunter. The only locality from which it has been reported is the one given above; there it grew in profusion. Doubtless it may be found at other localities on the same bay.

\section{Fucus evanescens f. dendroides Stroem.}

"F. evanescens suberectus, rigidus, stipite validissimo, trunciformi, basin versus incrassato, longe denudato, in costam supra sensim evanescentem abeunte; fronde flabelliformiter dichotoma, segmentis angustissimis, $2-8 \mathrm{~mm}$. latis, mediis costa prominente alatis summis ecostatis; receptaculis fusiformibus - anguste siliquaeformibus, $1-3 \mathrm{~cm}$. longis, interdum furcatis. minus verrucosis."

Stroemfelt, Om Alg.-veg. vid. Islands Kuster, 1886, pp. 35, 36, pl. 3. The type locality is Seley. Iceland.

Fronds distinctly caulescent, dense, coriaceous, 7-15 cm. high, rigid, terete at the base and for some distance among the main branches, tapering upward, the narrow alae having worn away leaving only the much enlarged midrib, flabellate-dichotomous, in part subsecund, profusely forked, dark olive green to olive brown, black on drying; segments strict, somewhat contorted, narrow, $5-8 \mathrm{~mm}$. wide in depauperate specimens, euneate to slightly linear, widest at the truncate apices, growing point slightly depressed, midrib prominent, percurrent; cryptostomata sparse or entirely absent; receptacles very abundant, single, retuse to bifureate, subfusiform to ovoid, considerably swollen, 1-3 cm. long; conceptacles numerous, emitting relatively long fascicles of paraphyses.

\section{Plate 41}

Growing on rocks exposed to fairly heavy surf, in the upper and middle littoral belts. Agattu Island to Sitka, Alaska.

Townsend, nos. 5755, 5756 (Herb. Univ. Calif., nos. 99105, 99106), Agattu, Alaska; Gardner, no. 2227 (Herb. Univ. Calif., no. 201148), Sitka, Alaska; Setchell and Lawson, no. 4052 (Herb. Univ. Calif., no. 99095, sub Fucus evanescens f. bursiger); Summer Bay, Alaska (cf. Setchell and Gardner, 1903, p. 285).

Stroemfelt, loc. cit.; De-Toni, Syll, Alg., 1895, p. 203; Setchell and Gardner, Alg. N.W. Amer., 1903, p. 284.

I first observed this plant in June, 1910, growing at Sitka, Alaska. A considerable area near the upper tide limit was completely covered with specimens. The plants were repeatedly branched, fruiting profusely, had a relatively large and strong holdfast and stipe, and varied from $7 \mathrm{~cm}$. to $15 \mathrm{~cm}$. in height. Some of the plants of Setchell and Lawson, referred to above, are only $4 \mathrm{~cm}$. high, those of Townsend are 
$15 \mathrm{~cm}$. to $18 \mathrm{~cm}$. high. Stroemfelt does not mention the height of the type in his diagnosis, but his illustration, natural size, is $14 \mathrm{~cm}$. high. The size of our plants, their narrow contorted segments, the character of the receptacles, the large firm holdfast and dendroid habit, agree so well with the description and figures of Stroemfelt as to leave little room for doubt as to the affinity of the two. Comparison with the type material may, however, show that the two sets of plants are distinct, as Stroemfelt does not mention the cryptostomata nor the caecostomata, nor does he mention the color, which is very striking in our plants. As the plants hang on the rocks after the receding tide, the shape, appearance, color, and abundance of receptacles reminds one of settled swarms of Italian bees.

\section{Fucus evanescens f. marginatus f. nov.}

Plate 42

Frons distincte caulescens, $20-50 \mathrm{~cm}$. alta, regulariter et multo dichotoma, evidenter rigida coriaceaque, valde contorta, luteola, siccata olivaceo-brunnea, stipite tereti, superne inter ramos diminuante; segmentis $9-15 \mathrm{~cm}$. latis, strictis, supra axillas non angustatis truncatis, vulgo linearibus, costa paululum prominente, parum evanida, alis inaequaliter attritis, cryptostomatibus fere absentibus; receptaculis $1.5-3 \mathrm{~cm}$. longis, definitis, integris aut alte bifureatis, anguste ellipticis, in margine dispositis; conceptaculis valde prominentibus.

Growing on roeks in the middle littoral belt. Sitka, Alaska.

Type, Gardner, no. 3997 (Herb. Univ. Calif., no. 201163), July, 1917.

The distinguishing characters of this form are absence of conceptacles from a complete margin of the receptacle, particularly of the rounded terminal portion, coupled with extreme sparsity of both cryptostomata and caecostomata.

It is difficult to decide to which species this form is most elosely related. It has evident affinities with Fucus evanescens Ag. and with F. spiralis L. Its color and consistency, coupled with the slightly vanishing midrib in the terminal segments, seem to ally it with $F$. evanescens, but, if allied with this species, it would be through $\mathrm{f}$. dendroides of Stroemfelt as its nearest relative. I have not seen the type nor any authentic specimens of $f$. dendroides, but since no one has questioned the validity of the form as belonging to $F$. evanescens, I am retaining it as such and grouping certain Alaska specimens with it. The narrow, rather long, considerably contorted and profusely branched 
fronds, the blunt and somewhat fusiform receptacles, and the dendroid habit certainly suggest its close similarity with f. dendroides. However, I am inclined to keep it distinct on account of its decidedly more robust habit. the practical absence of eryptostomata, the much lighter color than that of the other forms within our region which I have placed with f. dendroides, and the distinctly marginal receptacles.

Fucus spiralis, although, for modern usage, imperfectly deseribed by Linnaeus, has relatively recently been taken up by a number of algologists to include certain forms on both the European and the American shores of the Atlantic. Kjellman (1883, p. 202) definitely recognized it as a species, segregating, as new, f. borealis. In 1890 , however, he changed his conception of the species and named it $F$. Areschougii, segregating f. nana. De-Toni (1895, p. 207) recognized $F$. spiralis as a valid species and reduced Kjellman's F. Areschougii to strnontm. Börgesen (1902, pp. 472-477) followed De-Toni, and in a elear discussion reduced also $F$. platycarpus Thuret to a form of F. spiralis. Howe (1905, p. 581), after having examined the specimens in the Linnaean Herbarium supposed to represent Linnaeus' conception of $F$. spiralis, agrees with Börgesen's conception with regard to the validity of $F$. spiralis, considering as the typical form no. 234 of Collins' distribution from Maine in the Phycotheca Boreali-Americana sub $F$. Areschougii, and recently, in a letter to me, he states that he is inclined to place under this species most of the American plants which have previously passed for $F$. platycarpus of Thuret. Cotton, in Clare Island Survey, 1912, has kept up the name for certain forms in that locality. It seems thus to be quite well established as a species; the limits of variation, however, and the exact number of forms which should be grouped with it, have not yet been agreed upon. So far as I can learn, the name has not yet been used to designate any Pacific Ocean forms. Forma marginatus, under discussion, has some characters which might well link it with $F$. spiralis. It has the characteristically twisted segments in the upper part of the fronds, and the margined receptacles figured by Börgesen (loc. cit.), but the specimens of spiralis to which I have had access usually show an abundance of cryptostomata emitting fascicles of relatively long paraphyses, decidedly different in this respect from our plants. They also have shorter and more rounded receptacles and alae wider in proportion to the length of the segments. 
Fucus evanescens f. flabellatus f. nov.

Plate 43

Frondes 15-25 cm. altae, subcoriaceae, subdichotomae vel partim secundae, pallide brunneae vel luteolae, disco radicali parvo, stipite parvo, 2-3 cm. longo; segmentis linearibus vel paululum cuneatis, 10-15 mim. latis, strictis, apicibus rotundatis, parum truncatis, alis comparative tenuibus, costa infra receptaculis paullo diminuata, eryptostomatibus paucis, parvis, inconspicuis; receptaculis fusiformibus, $2-3.5 \mathrm{~cm}$. longis, integris aut bifurcatis, obscure definitis.

Growing on sandstone ledges in the middle of the littoral belt. Bellingham, Washington.

Type, Gardner, no. 2334 (Herb. Univ. Calif., no. 201168), July. 1910.

The majority of the plants seem scarcely mature at this season of the year, but enough of them were selected that appeared mature to be fairly certain that the measurements given for the receptacles are sufficiently accurate. The distinguishing character of the form is the pronounced fan-shape of the whole frond when spread out, and particularly of groups of segments, due to the secund method of branching.

The cryptostomata are relatively few and inconspicuous, and there is approximately the same number of caecostomata; thus in this character the form is on the border line between $F$. evanescens and $F$. furcatus. Probably the tendency is in the direction of the degeneration of these organs. The other characters, however, seem sufficiently well represented to ally it with $F$. evanescens.

\section{Fucus evanescens f. intermedius f. nov.}

Plate 44

Frondes foliaceae, flaccidae, $12-18 \mathrm{~cm}$. altae, obseure brunneae vel luteolae, siccatae castaneae disco radicali et stipite parvis, angulis latis, rotundatis; segmentis linearibus, supra axillas diminuatis, 1-2 $\mathrm{cm}$. latis, cryptostomatibus $12-25$ in quoquo $\mathrm{cm}$. quadrato, costa angusta, pereursa, alis comparative latis, membranaceis; receptaculis basi latis, 1-2-fureatis, acuminatis aut acutis, complanatis vel muco inflatis, distincte definitis; conceptaculis parvis, numerosis.

Growing on rocks in the middle of the littoral belt. East Sound, Oreas Island, Washington.

Type, Gardner, no. $2333 b$ (Herb. Univ. Calif., no. 205692), July. 1910 .

This forms seems unmistakably connected, through its narrow forms, with $F$. evanescens $\mathrm{f}$. costatus on one side, and, on the other 
side, through its widest speeimens, it seems not unlike certain narrow

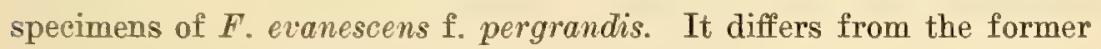
in having wider segments not pereeptibly reduced in width, as in f. costatus, above the forkings, and in having wider, much more robust and blunt receptacles. From the latter it differs in being much less robust throughout, in having fewer eryptostomata and in having much more delicate and membranaceous alae.

\section{Fucus evanescens f. macrocephalus Kjellm. \\ Plate 46}

" $f$. fronde caulescente; segmentis linearibus, subcoriaceis, $5-6 \mathrm{~mm}$. latis, costa parum prominente; receptaculis sublimitatis, magnis, 2.5$3.5 \mathrm{~cm}$. longis, $1.5-2 \mathrm{~cm}$. erassis plus minus turgidis, vel simplicibus ellipsoideis vel semel furcatis, euneatis, ramis subcylindricis, apice rotundatis ; scaphidiis magnis."

"Beringön, ymnig; sälskaplig inom litoralregionem tillsamman med föregående; med receptakler. '

Kjellman, Om Beringh. Algflora, 1889, p. 34.

Fronds subcaulescent, 12-18 em. high, subcoriaceous, dark brown below varying to light brown or yellowish above; segments linear to slightly cuneate, 5-12 mm. wide, midrib well developed, pereurrent, alae rather thin. eryptostomata absent or sparce; receptacles distinctly delimited. complanate in part, but mostly very tumid and mucilaginous. light yellow, 2-3.5 cm. long. 1-2 cm. wide, simple, retuse, or bifid; conceptacles conspicuous.

Plate 45

Growing in the middle of the littoral region. Bering Sea to Juneau, Alaska.

Newhall and Rhodes, nos. 5791, 5792 (Herb. Univ. Calif., nos. 99112, 99113), Cape Dyer, Alaska; MeGregor, no. 5689 (Herb. Univ. Calif., no. 99114), Dutch Harbor, Alaska; Setchell and Lawson, no. 4077 (Herb. Univ. Calif., no. 99120), Amaknak Island, Alaska; Setchell and Lawson, no. 5152 (Herb. Univ. Calif., nos. 99116, 99119), Orca, Alaska; Gardner, no. 2230a (Herb. Univ. Calif., no. 201134), Juneau. Alaska.

Kjellman, loc. cit.; De-Toni, Syll. Alg., 1895, p. 202 ; Saunders, Alg. Harriman Exp., 1901, p. 432, pl. 62, fig. 1; Setchell and Gardner, Alg. N.W. Amer., 1903, p. 282.

Saunders (1901, p. 432) reports this form as growing at Puget Sound, Annette Island, Wrangell, Juneau, Sitka, Glacier Bay, Prince William Sound. Cook Inlet. Kukak Bay, and Shumagin Islands, and states: "This is the most abundant seaweed on the northwest coast." I have not been able to examine any of the specimens of Saunders' 
collections, if such exist. There are no numbers quoted, and hence I will not attempt to place them. Most of the plants, particularly of the southern portion of the range, undoubtedly belong to $\mathrm{f}$. magnificus of this paper. The illustration (loc. cit.) might well represent $f$. macrocephalus, but it was not stated whence the specimen was collected. Kjellman's type specimen is illustrated on plate 46. It shows a plant with practically all the segments fruiting simultaneously, and the description calls for a plant relatively small, with narrow segments, 5-6 mm. wide. Plants which have been placed under this form are mostly very much larger in all parts, as well as differing in other respects. I doubt if the form should be considered as extending farther south than Juneau, Alaska, where it intermingles with forma magnificus. I have illustrated a plant from Juneau on plate 45, which I consider to be fairly typical. It is somewhat more robust than the trpe, and many of the receptacles are obcordate. The form is quite abundant at Juneau.

\section{Fucus evanescens f. pergrandis Kjellm.}

\section{Plate 47}

"F. evanescentis forma thallo $30 \mathrm{ctmr}$ et ultra alto, 1-2 ctmr lato, subcoriaceo, dichotomo, segmentis elongatis, costa parum prominente. receptaculis inflatis vel complanatis, indivisis, oblongo- ellipsoideis vel dichotomis, segmentis ovatis vel ellipsoideis."

"Fairhavn et Mosselbay in fundo pluriorgyali."

Kjellman, Om Spetsb. Thall., II, 1877a, p. 3.

Fronds caulescent, robust, subcoriaceous, up to $40 \mathrm{~cm}$. high, regularly dichotomous, dark brown below to yellowish brown above, black on drying; segments elongated, linear to slightly cuneate, 1-2 cm. wide, midrib distinct, percurrent, cryptostomata varying from none to 20 per \$q. cm.; receptacles numerous, mostly complanate, occasionally inflated, mucilaginous, $1-2.5 \mathrm{~cm}$. wide, $2.5-4 \mathrm{~cm}$. long, entire to bifid; conceptacles numerous, large.

\section{Plate 48}

Growing on boulders in the middle and upper littoral belts. Unalaska, Alaska, to Puget Sound, Washington.

Setchell and Lawson, nos. 3284, 4049 (Herb. Univ. Calif., nos. 99125, 99124), Amaknak Island, Alaska, and in Collins, Holden, and Setchell, Phyc. Bor.-Amer. (Exsice.), no. XLVI, sub F. platycarpus; Rev. Albin Johnson, no. 5701 (Herb. Univ. Calif,, no. 99126), Yakutat Bay, Alaska; Gardner, no. 2230 (Herb. Univ. Calif., no. 201136), Juneau, Alaska; Townsend, no. 5773 (Herb. Univ. Calif., no. 99129), Kyska Island, Alaska; Butler and Polly, no. 20 (Herb. Univ. Calif., no. 99127), Port Renfrew, British Columbia. 
Kjellman, loc cit.; De-Toni, Syll, Alg., 1895, p. 203; Setchell and Gardner, Alg. N.W. Amer., 1903, p. 284; Collins, Mar. Alg. Vancouver Island, 1913, p. 111.

The type locality of this form is Spitzbergen, where Kjellman says it grows at a depth of several fathoms. There are three fragments of the form in the Herbarium of the University of California, no. 132622, from Spitzbergen Islands, determined by Kjellman. These are represented on plate 36 and, although authentic, they do not entirely coincide with Kjellman's descriptions and type specimens as shorn on plate 47 . Apparently they are not representative specimens of this form. Plate 48 represents a form growing in the middle littoral belt at Juneau, Alaska. that coincides very closely with Kjellman's diagnosis and with plate 47 of his type specimen of forma pergrandis. A striking feature of the Juneau plants, however, is that practically every segment fruits at the same time. The Butler and Polly plant referred here is peculiar in being completely free from both caecostomata and cryptostomata. The Johnson plant referred here might be considered a very large specimen ( $45 \mathrm{~cm}$. long) of $F$. evanescens $f$. cornutus, and the Kjellman plants have sterile segments. The simultaneous fruiting of the segments in the Juneau plant would indicate a much shorter fruiting season than in such forms as f. magnificus, in which only a few of the segments are fruiting at any one time. It would be of much interest to know how constant and reliable these characters of fruiting or nonfruiting of segments are as an aid to the determination of species.

\section{Fucus evanescens f. robustus $\mathrm{S}$. and G. \\ Plates 49 and 50}

Fronds distinctly caulescent, 15-25 $\mathrm{cm}$. high, much contorted, with distinct stout stipe and holdfast, dichotomous, terminal portions foliaceous, olive green to dark olive brown; segments broadly cuneate, terminal lobes rounded, 15-28 mm. wide, midrib distinct, slightly reduced near the apices, alae membranaceous, cryptostomata sparse; receptacles broad, oblong, ovate or obcordate, very variable in size, $1.5-3.5 \mathrm{~cm}$. long, complanate, or much inflated, not mucilaginous, with distinct margin free from conceptacles which are large and projecting.

Growing on rocks in sheltered, shaded localities along extreme hightide limit. St. Paul Island, Alaska, to Friday Harbor, San Juan Island, Washington.

Setchell and Gardner, Alg. N.W. Amer., 1903, p. 283. Fucus platycarpus? Setchell, Alg. Prib. Isl. 1899, p. 593.

The type specimen was collected by Miss Ida M. Rogers, no. 5724 (Herb. Univ. Calif., no. 99133), at Sitka, Alaska. The writer collected 
it at Sitka in June, 1910, when it was in full fruit, and at Friday Harbor in July of the same year. The type and the two cotype specimens have all of the receptacles complanate, and are apparently immature (plate 49), but in the other collections mentioned many of the receptacles are much inflated (plate 50). The species is one quite free from mucilage as compared with other species of Fucus growing in the same localities but much lower down in the littoral belt. It seems to have become fixed as a form, and has the distinet habit, or character, of being able to persist in the upper two feet of the littoral belt, in which habitat it is necessarily uncovered the greater part of the twenty-four hours each day. It inhabits rock ledges, either steep or sloping, yet it is strictly confined to the upper, very narrow, belt. Its fronds are lighter and somewhat more fibrous than those of any other form.

\section{Fucus evanescens f. magnificus $f$. nov.}

Plates 51 and 52

Frondes foliaceae, $20-30 \mathrm{~cm}$. altae, subcoriaceae, dichotomae, vel partim secundae, inferne obscure brunneae, superne luteolae, siccatae olivaceo-brunneae; segmentis comparative brevibus, linearibus vel cuneatis, plus minus contortis, $2.5-3.5 \mathrm{~cm}$. latis, costa superne paiululum evanida, cryptostomatibus variis usque ad 50 in quoquo $\mathrm{cm}$. quadrato, vulgo paraphysum eristis exsertis quando juvenibus conspicuis ; receptaculis distincte definitis, valde tumidis, mucosis, integris vel decomposite furcatis, truncatis vel acutis, latitudine et longitudine valde variis, vulgo flavis; conceptaculis numerosis valde conspicuis.

Growing in great profusion in the middle and upper littoral regions. Juneau, Alaska, to Puget Sound, Washington.

Type, Gardner, no. 2337 (Herb. Univ. Calif., no. 205690), Griffin Bay, San Juan Island, Washington, July, 1910.

So far as my observations extend, this form seems to be the most abundant of all the forms included in the above mentioned region. It varies quite widely in the shape of the receptacles as shown in plate 51. Some receptacles are simple, others decompositely furcate, many quite obtuse, others decidedly acute, but all are definitely delimited and swollen almost to the bursting point with mucilaginous substance. The segments are wide and foliaceous, not narrowing at the forkings, and the tendency to the strict habit of growth often makes them quite contorted.

One of the distinguishing characters is the sparsity of receptacles maturing at any one time. This habit, marked in only a few of our forms, should receive more study in the field. My opinion is that the 
fruiting season extends over a much longer period than in most of the other forms. In the summer season, when I have observed them, one may find on the same individual receptacles varying from completely mature, to others just beginning to form, and many more sterile segments. The fronds fork. One branch of the dichotomy metamorphoses directly into a receptacle and the other continues to grow, and it in turn may fork one or more times without fruiting. This makes the mature receptacle appear to be lateral in origin, whereas in reality it originates just as all others do. This seems to be the condition prevailing in Thuret's F. platycarpus. Plate 16 in the Études Phycologique well illustrates this condition, but illustrates also another condition which does not seem to occur in f. magnificus, viz., that the suppressed fruiting segments are alternate, whereas in $f$. magnificus they are secund. I do not know how regularly the condition prevails in $F$. platycarpus, but this condition is too constantly prevalent in f. magnificus to be overlooked as a diagnostic character.

\section{Fucus evanescens f. stellatus f. nov.}

\section{Plate 53}

Frons distincte flaceida, vulgo contorta, $25-35 \mathrm{~cm}$. alta, dichotoma vel subdichotoma, inferne pallide brunnea, superne luteola, siceata obscure olivaceo-brunnea, stipite et disco radicali comparative parvis; segmentis comparative brevibus, cuneatis, ad apices latioribus, 1.5$2.5 \mathrm{~cm}$. latis, costa superne diminuante. cryptostomatibus paucis et inconspicuis; receptaculis distincte definitsi, complanatis, vel palulum tumidis, decomposite furcatis, vulgo patentibus acuminatisque, 3-4.5 cm. longis; conceptaculis numerosis, conspicuis.

Growing on boulders, $\log _{\mathrm{s}}$, etc., in the lower littoral belt. Sackman's Point, near Tracyton, Kitsap County, Washington.

Type, Gardner, no. 2202 (Herb. Univ. Calif., no. 201144), May, 1910. Fucus evanescens, Tilden, Amer. Alg. (Exsicc.), no. 235, same locality as above.

Tilden's no. 235 seems to belong here, although the specimen in Professor Setchell's copy of her American Algae is only a fragment and just beginning to produce receptacles.

The distinguishing character of this form is the decompositely furcate receptacles, often widely divergent. As many as eight divergent apices have been observed with a common base. The fronds are decidedly flaceid and dissolve rather readily in fresh water after being dried. 


\section{Fucus evanescens f. longifructus $\mathrm{S}$. and $\mathrm{G}$.}

Plate 54

Frond with short stipe and firm holdfast, somewhat caulescent below, foliaceous above, up to $45 \mathrm{~cm}$. high, dark olive brown; segments long and narrow, strict, 1-2 cm. wide, midrib moderately conspicuous, slightly evanescent, cryptostomata absent or very sparse; receptacles usually complanate, not definitely delimited, $2-2.5 \mathrm{~cm}$. wide, one to three times forked, with the divisions long, linear or sometimes recurved and pointed, up to $22 \mathrm{~cm}$. long; conceptacles very large and scattered.

Growing on stones in the upper littoral belt. Orca to Juneau, Alaska.

Type, Sețchell and Lawson, no. 5151 (Herb. Univ. Calif., no. 99110), Orea, Alaska. Collins, Holden, and Setchell, Phye. Bor.-Amer. (Exsice.), no. 928; Setchell and Lawson, no. 5186 (Herb. Univ. Calif., no. 99109), Juneau, Alaska.

Setchell and Gardner, Alg. N.W. Amer., 1903, p. 283.

A cotype specimen of this very distinct form is illustrated on plate 54, and it features the distinguishing characteristics very well. It is unlike all other forms in the extremely long, linear-lanceolate, regular complanate receptacles, frequently spreading or recurved at the apices. In external appearance it approaches $F$. furcatus $\mathbf{f}$. rigidus, but that form has an abundance of caecostomata, the receptacles usually more decompositely furcate, and it is more cartilaginous. No. 5186 from Juneau is placed here with some doubts. If it should be placed here, it should be considered at the lower limit of variation in size.

\section{Fucus evanescens f. cornutus Kjellm.}

\section{Plate 55}

"f. segmentis inferioribus ad costas demum reductis, superioribus linearibus, subcoriaceis, angustis, $3-4 \mathrm{~mm}$. latis, costa valida, at parum prominente; receptaculis sublimitatis, usque $4 \mathrm{~cm}$. longis, $5-10 \mathrm{~mm}$. crassis, turgidis, decomposito-furcatis, ramis inferioribus subcylindricis, summis subcoriaceis ; scaphidiis magnis."

"Beringön. ymnig; tillsamman med de båda föregående formerna, bildande en individrik Fucus-formation ; med receptakler."

Kjellman, Om Beringh. Algflora, 1889, p. 34.

Fronds subcoriaceous, $20-30 \mathrm{~cm}$. high, regularly dichotomous, dark olive green to dark olive brown; segments strict, linear or very slightly cuneate in the narrower specimens, $5-8 \mathrm{~mm}$. wide, apices truncate, midrib well developed, prominent, very slightly evanescent above, alae narrow, cryptostomata very sparse, small; receptacles distinctly 
delimited, mostly complanate, simple or bifurcate, blunt to acuminate, apices slightly laterally reflexed, 2-4 cm. long; conceptacles numerous, conspicuous.

Growing on rock ledges in the lower littoral belt. Yakutat Bay, Alaska.

Rev. Albin Johnson, no. 5719 (Herb. Univ. Calif., nos. 99103, 99104), Yakutat Bay, Alaska.

Kjellman, loc. cit.; De-Toni, Syll. Alg., 1895, p. 202; Setchell and Gardner, Alg. N.W. Amer., 1903, p. 283 (in part).

This form was first diseovered on Bering Island and deseribed by Kjellman (loc. cit.). Comparison with a photograph of the type (cf. plate 55) and with a small portion of the type specimen seems to make it fairly certain that the two specimens collected by Albin Johnson, and cited above, are correctly placed, although they are much larger in all parts than Kjellman's description calls for. Nore study of material in the northern waters is highly desirable to make certain this determination. In neither the type nor the other material referred to is the cornute habit very pronounced.

\section{Fucus evanescens f. typicus Kjellm.}

\section{Plate 56}

"F. evanescentis forma antecedente minor, thallo 5-10 mm. lato, coriaceo, dichotomo, segmentis elongatis, costa plus minus prominente, receptaculis vulgo complanatis et dichotomis, segmentis obovatis."

"Forma inter omnes vulgatissima per totam oram occidentalem et septemtrionalem Insulae Vestspetsbergen in fundo vulgo 2-5 orgyali."

Kjellman, Om Spets. Thall., II, 1877a, p. 3.

Fronds 15-25 cm. high, coriaceous, dichotomous, dark brown; segments cuneate to sublinear, midrib moderately distinct, percurrent, cryptostomata few, small; receptacles mostly complanate, deeply furcate, segments obovate to linear-acuminate.

Growing on rocks in the upper littoral region. Harvester and Kakiak Islands, Alaska.

Setchell and Lawson, no. 5122. (Herb. Univ. Calif., no. 99136), Harvester Island, Uyak Bay, Alaska; Rigg, no. 100, Kadiak Island, Alaska.

Kjellman, loc cit.; Setchell and Gardner, Alg. N.W. Amer., 1903, p. 282 .

Kjellman's type specimen of this form is illustraed on plate 56 , and represents a plant considerably smaller than the plants which I 
have allied with it from the Alaskan waters. No. 5122, in particular, is much more robust than Kjellman's description calls for. The receptacles are much longer and wider, but this may possibly be accounted for by difference in age. The plants collected by Rigg are smaller and more nearly coincide with the description. This plate shows Kjellman's plant to be about $10 \mathrm{~cm}$. high, possessing distinet midribs in many of the segments, and to have relatively small receptacles. There is a plant in the Herbarium of the University of California, sheet no. 132618, contributed by Kjellman and collected on Spitzbergen in " $1872-73$," labeled in Kjellman's handwriting, " Fucus evanescens Ag.," which is almost a duplicate of the type speeimen mentioned above. There is also a plant in the same herbarium, collected in 1868 from the same locality and determined by J. G. Agardh as $F$. evanescens $\mathbf{A g}$, whose fronds are about twice as wide as those of the Kjellman plants (cf. plate 56). Otherwise all of these three collections of plants are very much alike. The type specimen of $F$. evanescens Ag. is in the herbarium of J. G. Agardh at Lund under no. 00299. It has been examined by Professor Setchell, who states that the plant is slightly smaller than the plant referred to in Setchell and Gardner's Algae of Northwestern America, under f. typica, from Harvester Island, Alaska. This plant is in the Herbarium of the University of California under no. 99139. It differs only slightly from the wide form of $F$. evanescens from Spitzbergen, mentioned above, having more numerous, larger, and better developed receptacles. There is much greater disparity of size between this specimen and Kjellman's f. "typica" than there is between Kjellman's f. "typica", and his $f$. "limitata." If we admit the specimen determined by J. G. Agardh from Spitzbergen as belonging with f. typica Kjellman, then the Harvester Island specimen which is so close to it had probably better be allied with it at present, until more is known of the forms from that island. However, it also seems very close to Kjellman's f. "cornuta," but has wider fronds and receptacles than the type specimen of that form.

I am referring here a series of plants collected on Kadiak Island, Alaska, by G. B. Rigg, no. 100. These plants are only slightly wider than the type specimen of Kjellman, and have numerous well developed receptacles. They appear to be the closest in all characters to the type, and I am taking them to be the best representatives of $\mathbf{f}$. typicus thus far discovered in Pacific Coast waters. 


\title{
Fucus evanescens f. rudis Kjellm.
}

\author{
Plate 57
}

"f. fronde caulescente; segmentis inferioribus valide costatis, cuneiformibus, superioribus coriaceis, costa plus minus prominente, $1-1.5 \mathrm{~cm}$. latis; receptaculis maximis, inferne non limitatis, raro simplicibus, ambitu lineari ellipticis, vulgo plus minus decompositofurcatis, segmentis sublinearibus ; scaphidiis magnis."

"Fig. Fucus vesiculosus Post. et Rupr., Ill. Alg., t. 30."

"Beringön. ymnig; sällskaplig inom litoralregionen; med receptakler."

Kjellman, Om Beringh. Algflora, 1889, p. 34.

Fronds somewhat eaulescent, coriaceous, dark brown, dichotomous; segments strict, cuneate, 1-2 cm. wide, reduced at the forking, terminal lobes truncate, midrib narrow but distinct to the apices, eryptostomata absent or rare; receptacles relatively large, $3.5-5 \mathrm{~cm}$. long, rarely complanate, mostly very tumid and mucilaginous, not definitely delimited.

Growing in the lower littoral and upper sublittoral regions. Bering Sea to Skagway, Alaska.

Setchell and Lawson, no. 5121 (Herb. Univ. Calif., no. 99131), Harvester Island, Uyak Bay, Alaska. Fucus evanescens f. macro. cephalus, Setchell and Lawson, no. 5178 (Herb. Univ. Calif., nos. 99117, 99118), Orea, Alaska; A. L. Bolton (Herb. Univ. Calif., no. 99115), Skagway, Alaska.

Kjellman, loc. cit.; De-Toni, Syll. Alg., 1895, p. 202 ; Setchell and Gardner, Alg. N.W. Amer., 1903, p. 282. Fucus vesiculosus Postels and Ruprecht, Ill. Alg., 1840, p. 12, pl. 25 (cf. Kjellman, loc. cit.).

Kjellman cites plate 30 of Postels and Ruprecht, Illustrationes Algarum, as representing this form. Plate 30 is labeled "Constantinea rosa marina," but has in addition a small plant of Fucus. This plant has long, acuminate receptacles. Plate 25 of the same work, to which Kjellman probably refers, is labeled Fucus vesiculosis and has decompositely furcate receptacles with long, acuminate apices. The plants referred here by Setchell and Gardner (1903, p. 282) have the characteristic receptacles referred to above. Comparison with a photograph of Kjellman's type specimen hardly bears out his conclusion regarding the illustration in Postels and Ruprecht. The fronds are reduced in width above each forking. Some of the receptacles are relatively wide, others are very narrow, and those of Kjellman's type, which I have seen, are very blunt. Some doubts must be entertained as to the limits of this form. I am referring here plants from Orea and Skagway, cited above, as more nearly coinciding with Kjellman's type. 


\section{Fucus evanescens $\mathrm{f}$. irregularis Kjellm.}

"f. cirea $15 \mathrm{~cm}$. alta, fronde crebre irregulariter dichotoma, segmentis plurimis ad costas validas reductis, summis tantum alatis, angustis, obsolete costatis, apicibus truncatis; receptaculis limitatis ovatis, obovatis, oblongis vel obeordatis; scaphidiis minoribus." takler."

"Beringön, sparsam; spridd inom litoralregionen; med recep-

Kjellman, Om Beringh. Algflora, 1889, p. 35.

A photograph of the type specimen indicates to me that this form, segregated by Kjellman on Bering Island, is hardly to be considered an entity but rather a battered and distorted plant of some other form. To my knowledge it has not been recognized since its original discovery ; but if a valid form, it is quite likely to occur on the North American side of the Pacific Ocean, hence I am including it here as a possibility.

\section{Fucus evanescens f. limitatus Kjellm.}

\section{Plate 58}

"f. fronde caulescente; segmentis tenuioribus, submembranaceis, subdivaricatis, infimis cuneato-linearibus, superioribus sublinearibus, 3-5 mm. latis; costa parum prominente; receptaculis distincte limitatis, subpetiolatis vel simplicibus, ovato-ellipsoideis vel semel fureatis. ramis plus minus longis, divaricatis, apice rotundatis."

"S :t Lawrencebay, Port Clarence, på båda ställena temligen ymnig ; något sällskaplig inom sublitoralregionen; med receptakler."

Kjellman, Om Beringh. Algflora, 1889, p. 34.

Fronds caulescent or subcaulescent, submembranaceous, dichotomous, spreading, with rounded angles, yellowish brown, darker brown on drying; segments short, cuneate-linear, apices rounded, truncate, midrib distinetly reduced upward, eryptostomata few; receptacles distinctly delimited, subpedicilate, seemingly lateral, entire or bifureate, ovoid-ellipsoidal, $12-18 \mathrm{~mm}$. long, 8-12 mm. wide.

Plate 59

Growing in the upper sublittoral belt. Port Clarence to Norton Sound, Alaska.

Kjellman, Port Clarence, Alaska; R. C. MeGregor, no. 5683 (Herb. Univ. Calif., no. 99107), Besbora Island, Norton Sound, Alaska.

Kjellman, loc. cit.; De-Toni, Syll. Alg., 1895, p. 202 ; Setchell and Gardner, Alg. N.W. Amer., 1903, p. 282.

The only material of which I am aware that has previously been referred to this form since its establishment by Kjellman is that referred by Setchell and Gardner (loc.cit.) from Norton Sound, and the same material, two small fragments of plants, is again referred 
here to the same form, though with some doubt. It is evidently a small form and, according to Kjellman, grows in the sublittoral belt, an unusual habitat for small forms, or even other forms outside of the Arctic regions. It may be noticed from the illustration (plate 59) that the Norton Sound specimens have a decided habit of growth which is not very common among the forms of the genus, viz., one of the members of a dichotomy develops into a receptacle, while the other continues to grow and forks one to several times before the receptacle of the original dichotomy matures and disintegrates. This makes the receptacle appear to have developed laterally. The illustration (plate 58) of the type specimen does not show this character, practically all of the segments fruiting simultaneously. More study of this character is highly desirable.

\section{Fuscus evanescens f. contractus Kjellm.}

"f. 5-10 cm. alta, fronde vix caulescente, subirregulariter furcata, segmentis subcoriaceis, infimis cuneato-linearibus, superioribus linearibus, $3-5 \mathrm{~mm}$. latis, apieibus truncatis; costa inferne valida, prominente, superne evanescente; receptaculis limitatis, complanatis, minoribus, ambitu ellipticis vel obcordatis ; scaphidiis parvis."

"S:t Lawrence-ön, temligen ymnig; năgot sällskaplig inom litoralregionen ; med receptakler."

Kjellman, Om Beringh. Algflora, 1889, p. 34.

Fronds 5-25 cm. high, slightly caulescent, subcoriaceous, irregularly dichotomous or subsecund, dark brown to yellowish; segments mostly strict, cuneate-linear below, linear above, 3-10 $\mathrm{mm}$. wide, apices truncate, midrib distinct below, vanishing above, eryptostomata moderately abundant, $15-20$ per sq. cm., inconspicuous; receptacles complanate, distinctly delimited, $1.5-3.5 \mathrm{~cm}$. long, ellipsoidal or obeordate, single or bifid; conceptacles few, but prominent.

Growing in the littoral region. Bering Sea, Alaska.

Setchell, nos. 5239, 5252 (Herb. Univ. Calif., nos. 99097, 99101), St. Michael, Alaska; MeGregor, nos. 5673, 5679 (Herb. Univ. Calif., nos. 99099, 99100), Golofin Bay, Alaska. Not Gardner, no. 90 (Herb. Univ. Calif., no. 99096), Whidbey Island, Washington, sub $F$. evanescens f. bursiger (cf. Setehell and Gardner, 1903, p. 285).

Kjellman, loc. cit.; De-Toni, Syll. Alg., 1895, p. 202; Setchell and Gardnex, Alg. N.W. Amer., 1903, p. 284.

Kjellman does not mention in his description of this form the decided and sudden difference between the width of the segments and the receptacles which they bear. This difference makes the receptacles appear stipitate, since they are over twice as wide at the base of the segments. Presumably this is the character upon which the form is based. 
No. 5652 (Herb. Univ. Calif., no. 99101) from St. Michael, Alaska, quoted above, is as near the type as could be desired in every particular. The plants are about $10 \mathrm{~cm}$. high, thus representing the upper limits in size as stated by Kjellman. The plants under the other numbers referred to are all larger in all parts than the measurements given by Kjellman, but they seem too closely linked to the type to warrant separation without further study of quantities of material in the field. There is not the sudden widening of the receptacles in any of the latter forms as in the type. The receptacle character seems more closely allied to that of $\mathrm{f}$. microcephalus.

\section{Fucus evanescens f. angustus Kjellm.}

"Fuci evanescentis forma thallo subdichotomo, usque 20-30 ctmr alto et $4-5 \mathrm{~mm}$. lato, coriaceo vel coriaceo-membranaceo, costa inferne valida, versus apicem sensim evanescente, in thalli partibus summis vix conspicua vel inconspicua, segmentis linearibus vel cuneato-linearibus, elongatis, cryptostomatibus numero variantibus, parum prominentibus, receptaculis minutis, oblongis, ovatis vel late ellipsoideis, obtusis vel acutis, inflatis vel plus minus complanatis, scaphidiis hermaphroditis, antheridiis interdum perpaucis; exsiceatione nigrescit."

"N. Gänse Cap; Rogatsehew Bay.",

Kjellman, Algenv. Murm. Meer, 1877, p. 27.

This form of evanescens, first described by Kjellman, has not been clearly identified with any specimens from our region, but is here included because of its close resemblance to certain of our forms, and hence the probability of its oceurrence within our waters would seem to warrant its inclusion.

Yendo (1917, p. 16, pl. 1, fig. 1) identifies a plant of the Japanese waters with this form. Setchell and Gardner (1903, p. 284) also identified plants from East Sound and Fairhaven, Washington, with this form, and specimens from East Sound were distributed in Collins, Holden, and Setchell's Phycotheca Boreali-Americana, no. 926. On comparison of our plants with a sheet of plants in the Herbarium of the University of California, no. 132699, collected on the Vega expedition near Tjapka and contributed and labeled by Kjellman, Fucus evanescens $\mathrm{f}$, angustus, it seems best to change the determination and to place our plants under Fucus enlentatus $\mathrm{f}$. costatus, under which a detailed account is given. The plants illustrated by Yendo differ decidedly from the Kjellman specimens referred to above, particularly in the size of the receptacles and the prominence of the midrib. It may be doubted whether this form really extends so far south on 
either coast of the Pacific Ocean as was previously supposed, but its occurrence farther north may well be expected.

Fucus ceranoides f. Harveyanus (Dec'ne) Kjellman, collected and determined by De Alton Saunders at Pacific Grove, California, and distributed in Tilden's American Algae, no. 339, is Hesperophycus Harveyanus (Dec'ne) S. and G., in Gardner, Variation in Nuclear Extrusion, 1910, p. 127, and in Gardner, New Fucaceae, 1913, p. 317, pls. 36,37 .

In conclusion, it affords me much pleasure formally to acknowledge my sincere gratitude to Professor W. A. Setchell for encouragement and many valuable suggestions in the preparation of this work, to Dr. M. A. Howe and Dr. Carl Skottsberg for prints of photographs of type specimens, and to Mr. T. S. Brandegee for rendering the Latin diagnoses of the new species and forms presented here.

AGARDH, C. A.

\section{LITERATURE CTTED}

1820. Species algarum rite cognitae cum synonymis, differentiis specificis et deseriptionibus suceinctis, vol. 1, part 1, pp. 1-268. Lund.

1821. Icones algarum ineditae, fasc. 2. Stoekholm.

1824. Systema algarum. Lund.

AGARDH, J. G.

1848. Species genera et ordines Algarum, vol. 1. Lund.

1868. Bidrag till Kännedomen af Spetsbergens Alger. Tillägg till föregående afhandling. Kongl. Sv. Vet.-Akad. Handl., vol. 7, no. 8. Stockholm.

BaKER, SARAH M.

1912. The brown seaweeds of the salt marshes. Journ. Linn. Soc. Bot., vol. 40, pp. 275-291, pls. 8, 9, 8 text figures.

Bakerr, Sarah M., and Bohling, Madde H.

1916. On the brown seaweeds of the salt marshes. Part 2, Their systematic relationships, morphology and ecology. Journ. Linn. Soc. Bot.,

BÖRGESEN, F. vol. 43 , pp. $235-380$, pls. $28-30,18$ text figures.

1902. The marine algae of the Faeröes, in Warming, Botany of the Faeröes, BOWER, F, O part 2, pp. 339-532, Copenhagen.

1880. On the development of the conceptacles in the Fucaceae. Quart. Jour. Micr. Sci., vol. 20, n.s., pp. 36-49.

Collins, F. $\mathbf{8}$.

1913. The marine algae of Vancouver Island. Canada Geological Survey. Vietoria Memorial Museum, Bulletin no. 1, pp. 99-137. Victoria, B. C.

Collins, F. S., Holden, I., ANd Setchell, W. A.

Phycotheca Boreali-Americana (Exsice.), fase. 5, 19, 27, B, D, E. 
Cotton, A.D.

1912. Claire Island Survey, part 15, Marine algae. Proc. Roy. Irish Acad., vol. 31, pp. 1-187, pls. 1-11. Dublin.

De la Pylaie, B.

1829. Flore de Terre-Neuve et des îles Saint Pierre et Miclon avec figures dessinées par l'auteur sur la plante vivante, plate 17. Paris. [The plate of this work was never published.]

DE-ToNT, J. B. (or G. B.)

1895. Sylloge algarum omnium hueusque cognitarum, vol. 3, Fucoideae.

FARLOW, W. G.

1881. Marine algae of New England and adjacent coast. Rep. U. S. Fish Comm., 1879. Washington.

1889. Some new and imperfeetly known algae of the United States I. Bull. Torr. Bot. Club, vol. 16, pp. 1-12, pls. 87, 88.

Farlow, W. G., Anderson, C. L., and Eaton, D. C.

Algae Exsiceatae Americae Borealis, no. 108.

Fostie, M.

1886. Kritisk fortegnelse over Norges havsalger efter aeldre botaniske arbeider indtil aar 1850. Tromsö Museums Aarshefter, vol, 9. Tromsö.

GARDNER, N. L.

1910. Variations in nuclear extrusion among the Fucaceae. Univ. Calif. Publ. Bot., vol. 4, no. 6.

1913. New Fucaceae. Ibid., no. 18.

GMELIN, S. G.

1768. Historia Fucorum.

HARVEY, W. H.

1830-1841. Algae, in Hooker and Arnott's Botany of Captain Beechy's voyage. London.

1862. Notice of a collection of algae made on the north west coast of North America, chiefly at Vancouver's Island by Dr. David Lyall, 18591861. Jour. Proc. Linn. Soc., Bot., vol. 6, pp. 157-177. London.

How $\mathrm{E}, \mathrm{M} . \mathrm{A}$.

1905. Phycological studies II. New Chlorophyceae, new Rhodophyceae and miscellaneous notes. Bull. Torr. Bot. Club, vol. 32, pp. 563-586, pls. 23-29.

KJELLMAN, F. R.

1877. Ueber die Algenvegetation des Murmanschen Meeres an der westküste von Nowaja Semlja und Wajgatsch. Nova Acta, Reg. Soc. Sei., ser. 3. Upsala.

1877a. Om Spetsbergens Marina Klorofyllförande Thallophyter II. Bihang till Kongl. Sv. Vet.-Akad. Handl., vol. 4, no. 6. Stoekholm.

1883. The algae of the Aretic Sea. Kongl. Sv. Vet.Akad. Handl., vol. 20, no. 5 .

1889. Om Beringhafvets algflora. Ibid., vol, 23, no. 8.

1890. Handbok I Skandinaviens Hafsalgflora. I, Fucoideae. Stockholm.

KLEEN, E. A. G.

1874. Om Nordlandens högra hafsalgar.' Akademisk afhandling Oefversigt af. Kong. Vet.Akad. Förhandl, no. 9. Stockholm. 
KUETZING, F. T.

1849. Species algarum. Leipzig.

1860. Tabulae phycologicae, vol. 10.

LINNAEUS, C.

1753. Species plantarum, exhibentes plantas rite cognitas, ad genera relatas, cum differentiis specificis, nominibus trivialibus, synonymis selectis, locis natalibus secundum systema sexuale digestas. Ed. 1. Stoekholm.

EDER, G. C.

1767. In Flora Danica, จol. 2, fasc. 6, tab. 351.

OLtmanas, F.

1901-1905. Morphologie und Biologie der Algen. 1904, vol. 1; 1905, vol. 2. Jena.

Postris, A., AND RUPRECHT, F.

1840. Illustrationes algarum in itinere circa orbem jussu imperatoris Nicolai I. Atque auspiciis Navarchi Friderici Lütke annis 1826, 1827,1828 et $1829^{\prime}$ celoce seniavin exsecuto in Oceano Pacifico, inprimis septemtrionali ad littora Rossica Asiatico-Americana collectarum. St. Petersburg.

REINKE, J.

1875. Ueber Fucus vesiculosus. Nachrichten von der Königl. Gesell. der Wissen. und der G. A. Univ. zu Göttingen, no. 9, pp. 225-241.

ROSENTINGE, L. K.

1893. Grönlands Havalger. Meddelelser om Grönland, vol. 3, pp. 765-981. Copenhagen.

RUPRECHT, F, J.

1851. Tange des Ochotskischen Meeres. Middendorff's Sibirische Reise, vol. 1, part 2, lieferung 2, p. 193.

SAUNDERS, De A.

1901. Papers from the Harriman Alaska Expedition, 25, the Algae. Proc. Wash. Acad. Sci., vol. 3, pp. 391-486, pls. 43-62. Washington.

SETCHell, W. A.

1899. Algae of the Pribilof Islands, in Jordan, Fur seals and fur-seal islands of the north Pacific Ocean, vol. 3, pp. 589-596, pl. 95. Washington.

SETCHELL, W. A., AND GARDNER, N. L.

1903. Algae of Northwestern America. Univ. Calif. Publ. Bot., vol. 1, no. 3, pp. 165-418, pls. 17-27.

STROEMFELT, H. F. G.

1886. Om Algenvegetationen vid Islands Kuster. Akademisk Afhandling Köngl. Vet. och Vitt. Samh. Handl. Göteborg.

TILDEN, JOSEPAINE

American Algae (Exsice.), Centuries 3, 4.

VABR, M.

1794. In Flora Danica, vol. 7, fase. 19, tab. 1127.

YENDO, K.

1907. The Fucaceae of Japan. Jour. Coll. Sci. Imp. Univ. Tokyo. 


\section{EXPLANATION OF PLATES}

\section{PLATE 1, FIGURE 1}

Fucus furcatus $\mathbf{A g}$.

A reproduction of the original in Icon. Alg. Ined., pl. 14. Natural size.

PLATE 1, FIGURE 2

Fucus evanescens Ag.

A reproduction of Agardh's original figure in Icon. Alg. Ined., plate 13. Seven-tenths original size. 

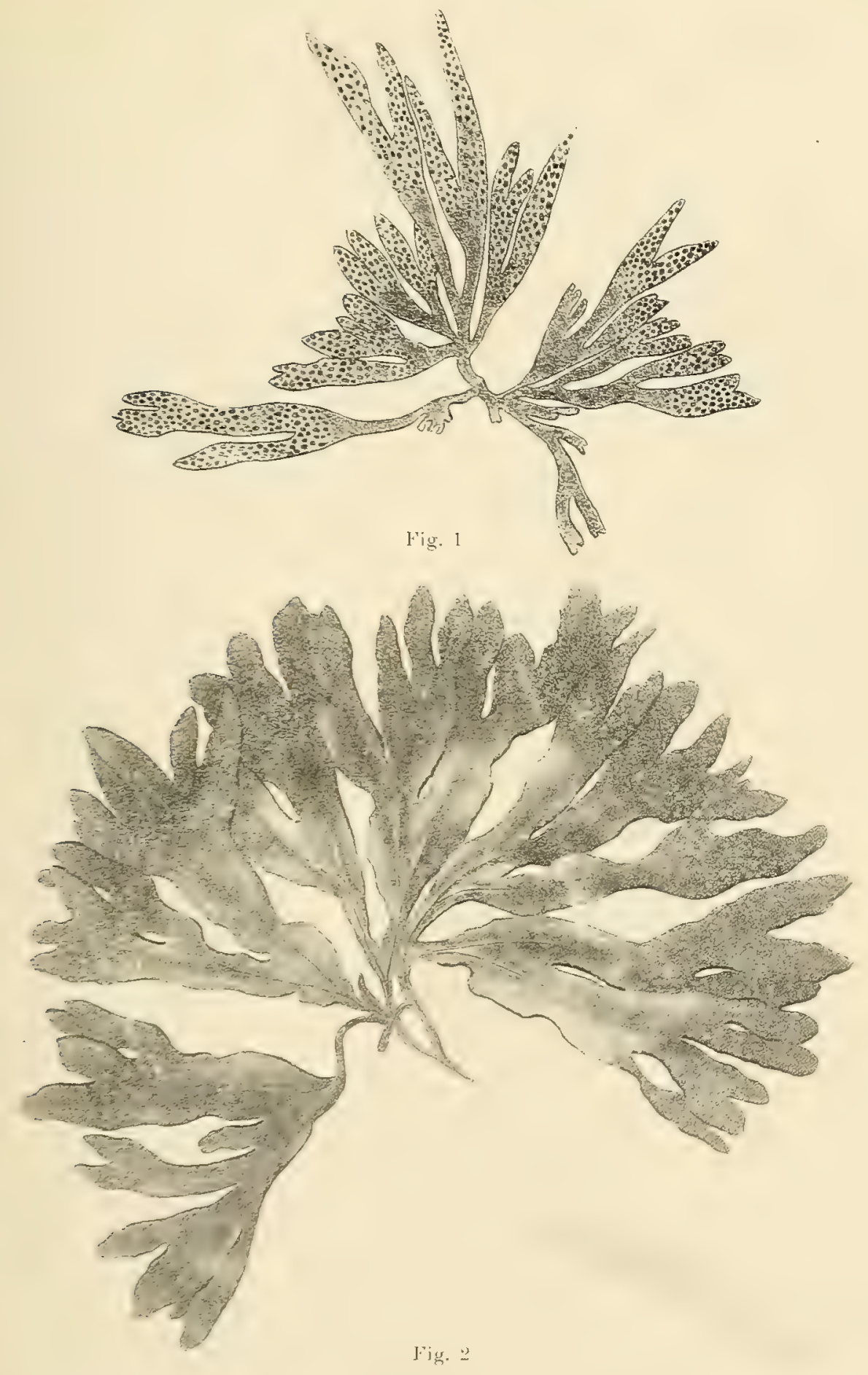
PLATE 2

Fucus furcatus f. typicus Gardner

From a photograph of the type from herbarium specimens collected at Fort Ross, California, presumably the type loeality of the species. One-third natural size. 


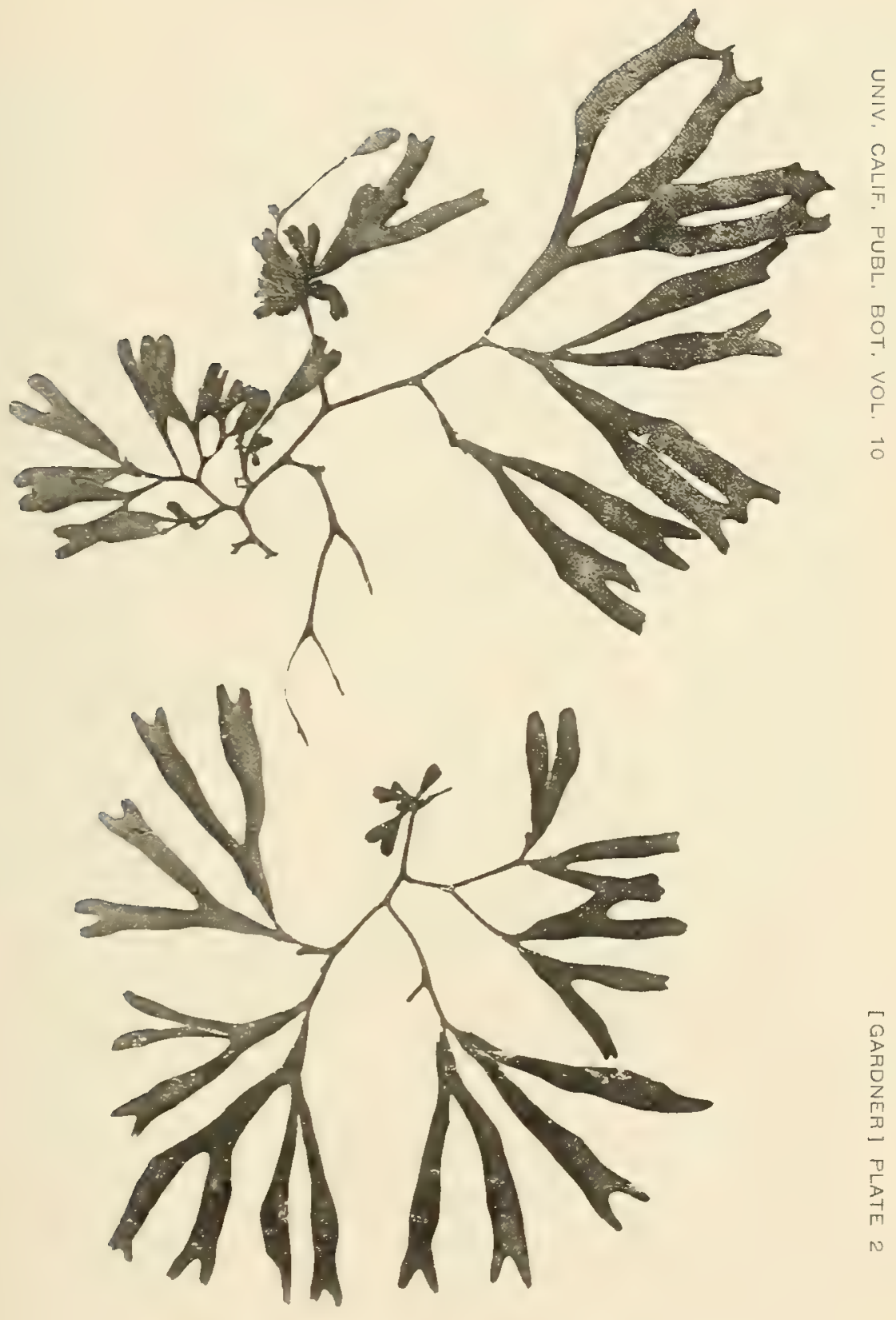


PLATE 3

Fucus furcatus $\mathbf{f}$. typicus Gardner

From a photograph of a living plant with immature receptarles. One-half natural size. 


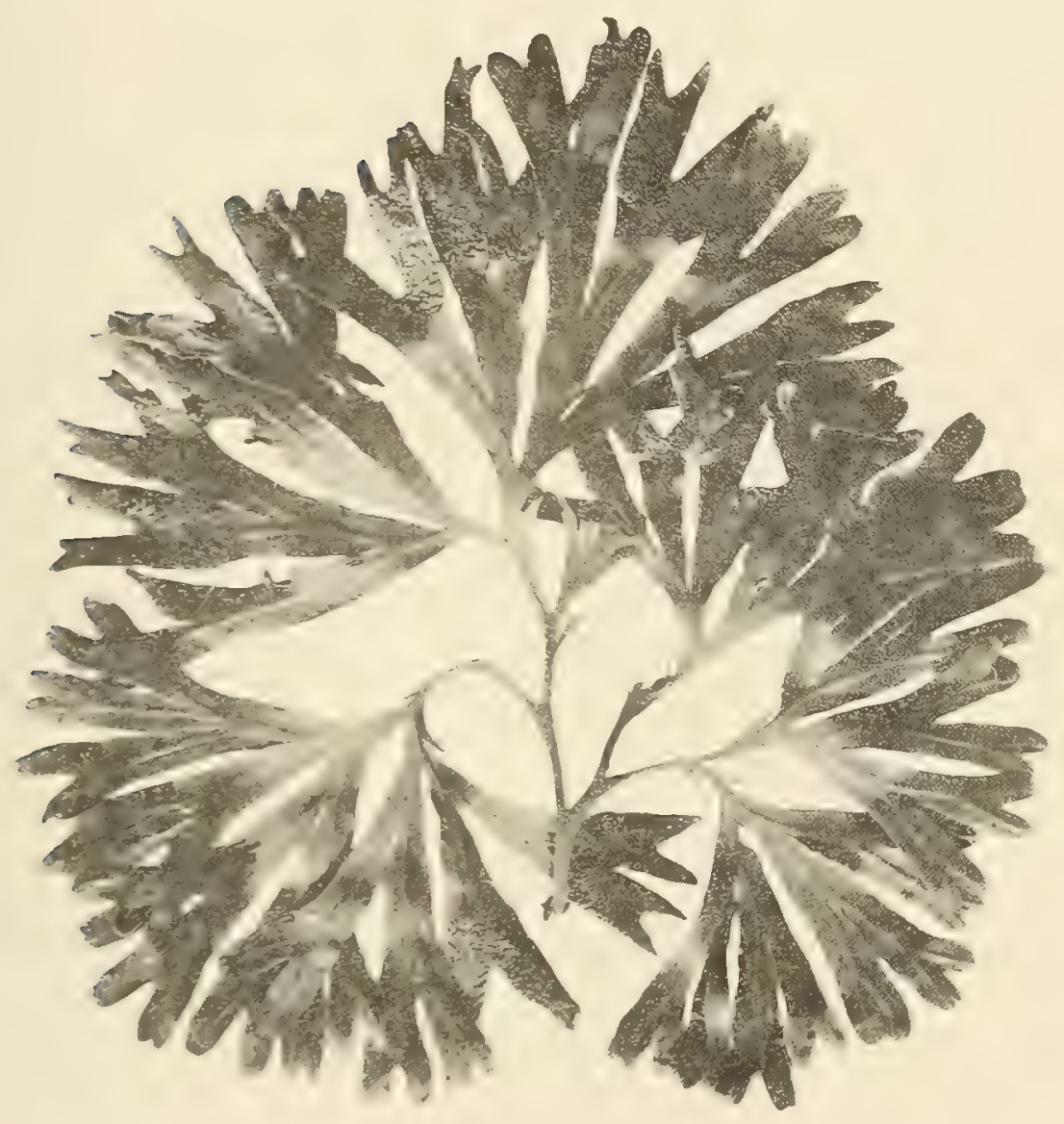




\section{PLATE 4}

Fucus furcatus $\mathbf{f}$. angustus Gardner

From a photograph of the type specimen showing a regeneration of one branch of the first dichotomy. Two-fifths natural size. 


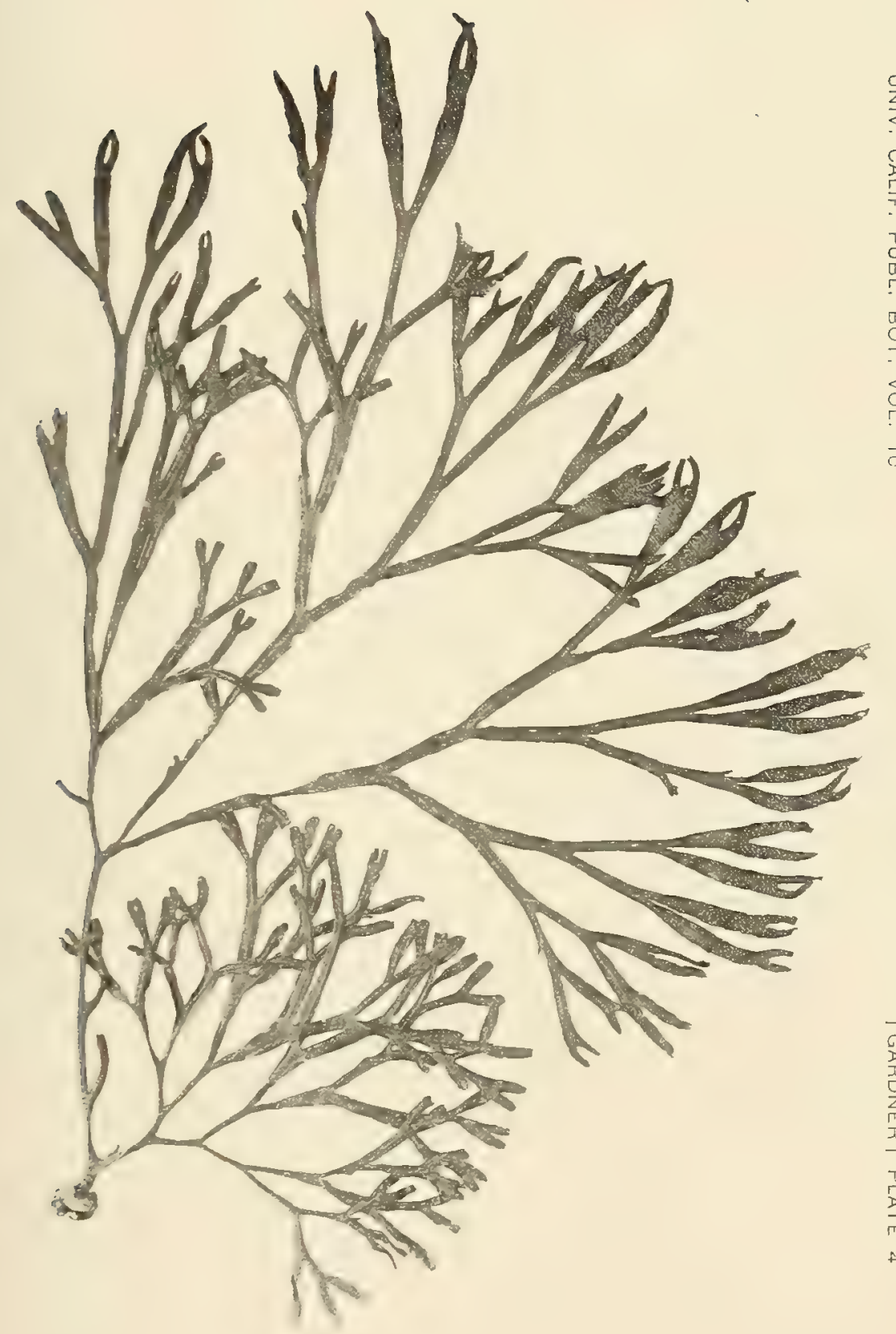

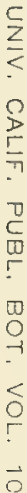

0
0
30
0
$m$
$m$
7
7
5
7
7
7
1 
PLATE 5

Fucus furcatus f. Tinearis Gardner

From a photonrall of a portion of the type specimen showing every terminal segment to be fruiting. About one-fourth of the original plant. Oue-third natural size. 


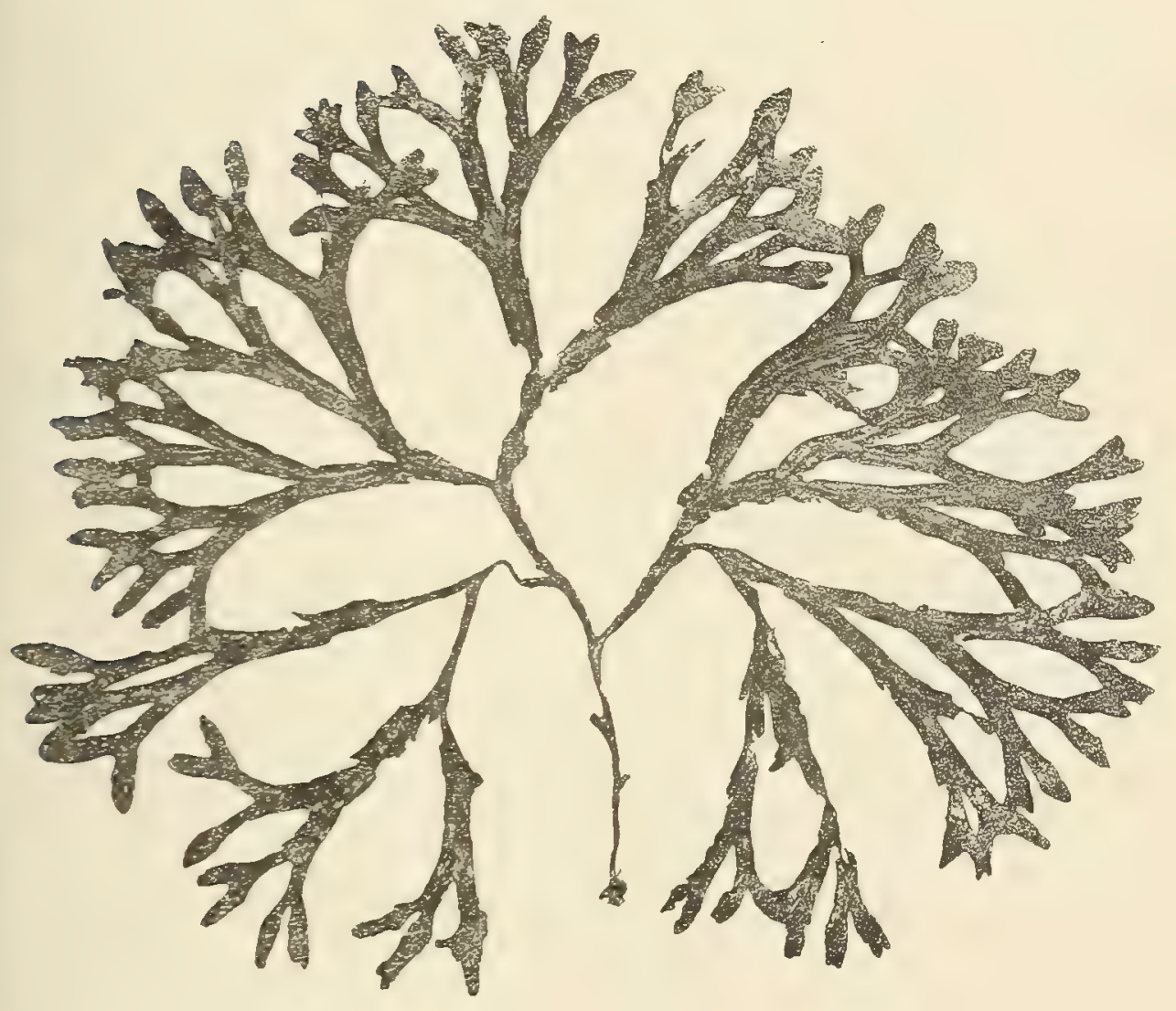


PLATE 6

Fucus furcatus f. abbreviatus Gardner

From a lohotonraph of fiesh material of the type slevimen, showing relatively larige, wide and sourcely matured receptateles. Three-fourths natural sizc. 


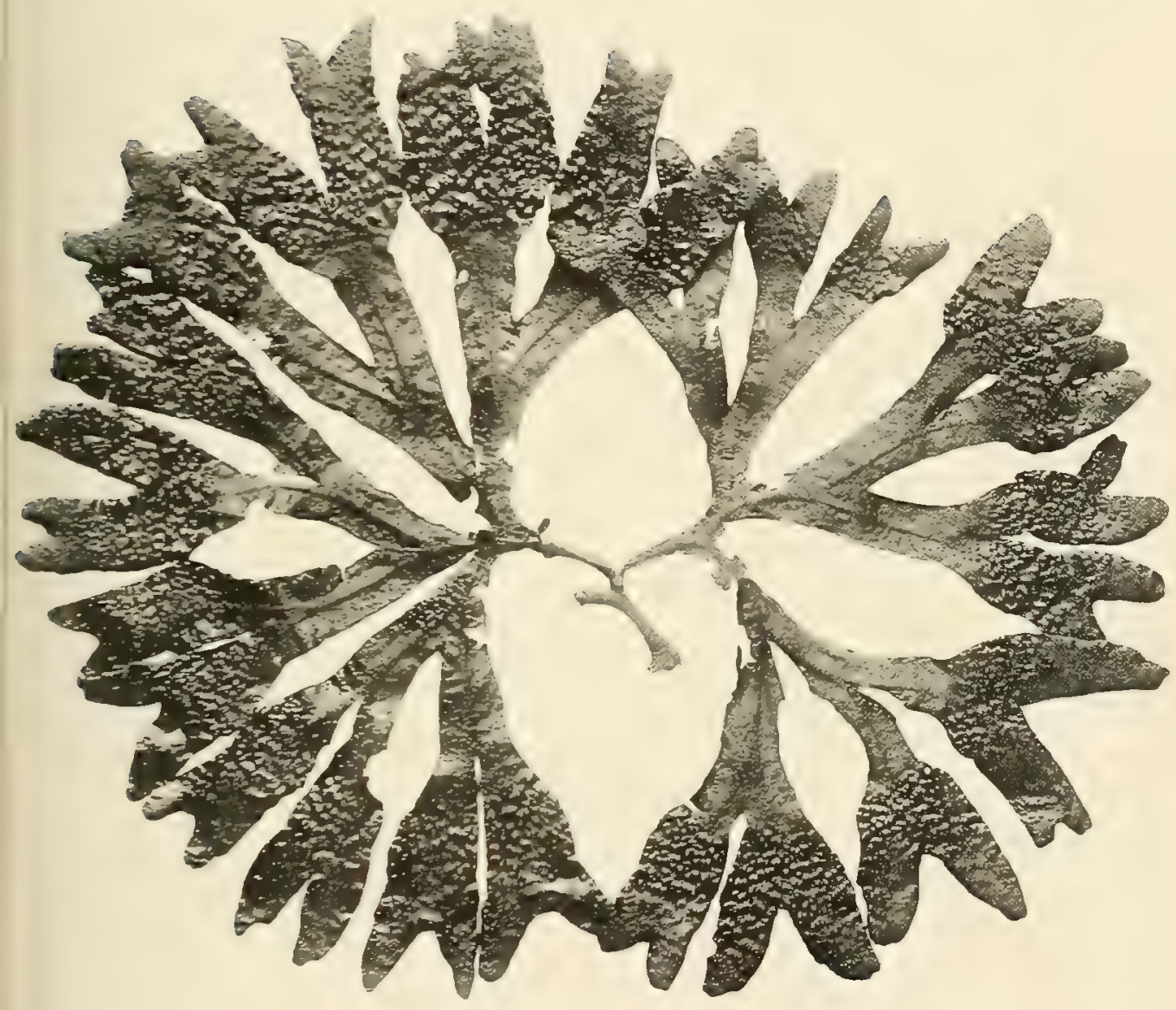


PLATE 7

Fucus furcatus $\mathbf{f}$. cornutus Gardner

From a photograph of the type specimen. Two-thirds natural size. 


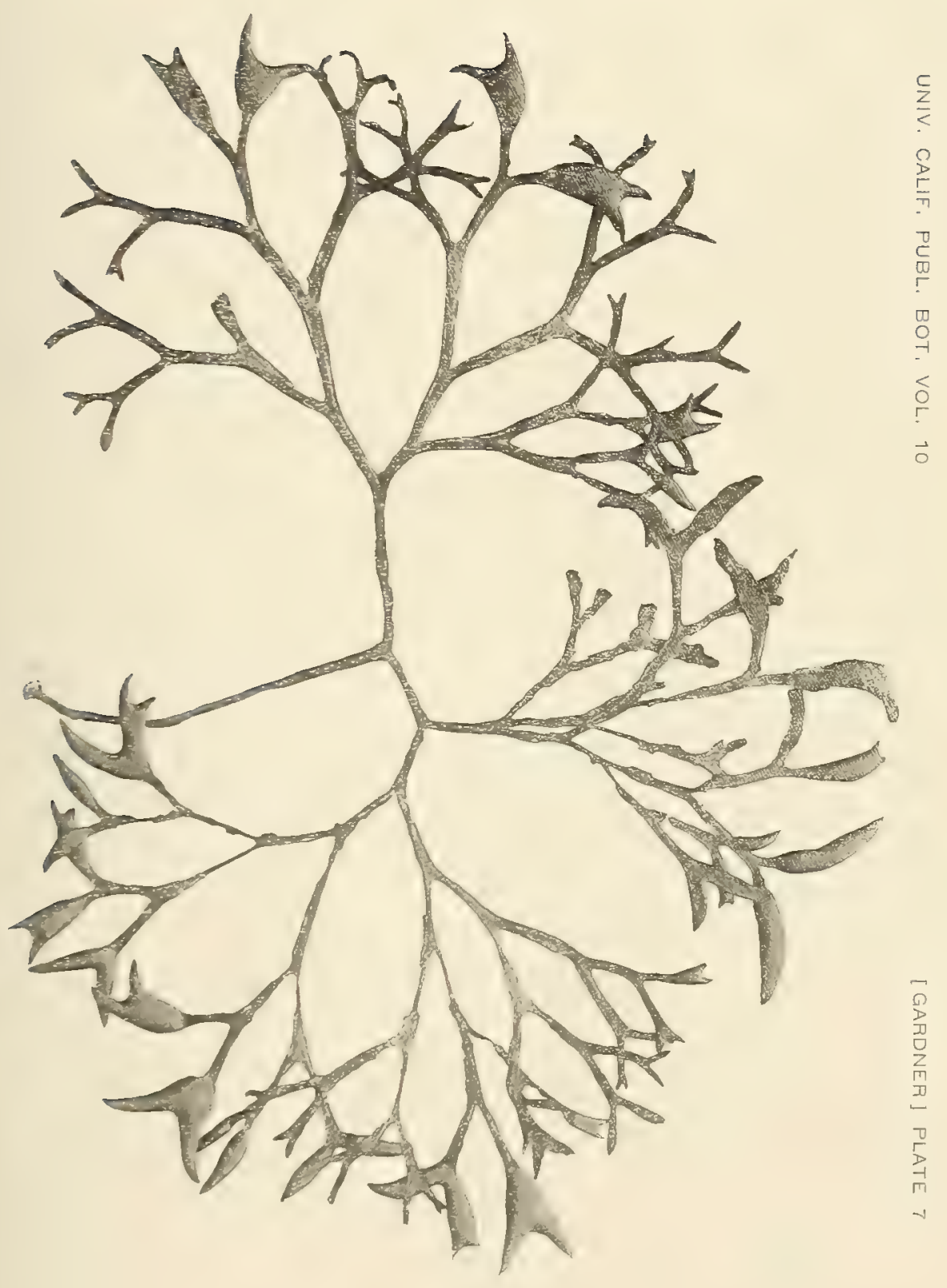


PLATE 8

Fucus furcatus $\mathrm{f}$. nigricans Gardner

From a photograph of the type specimen. One-third natural size. 


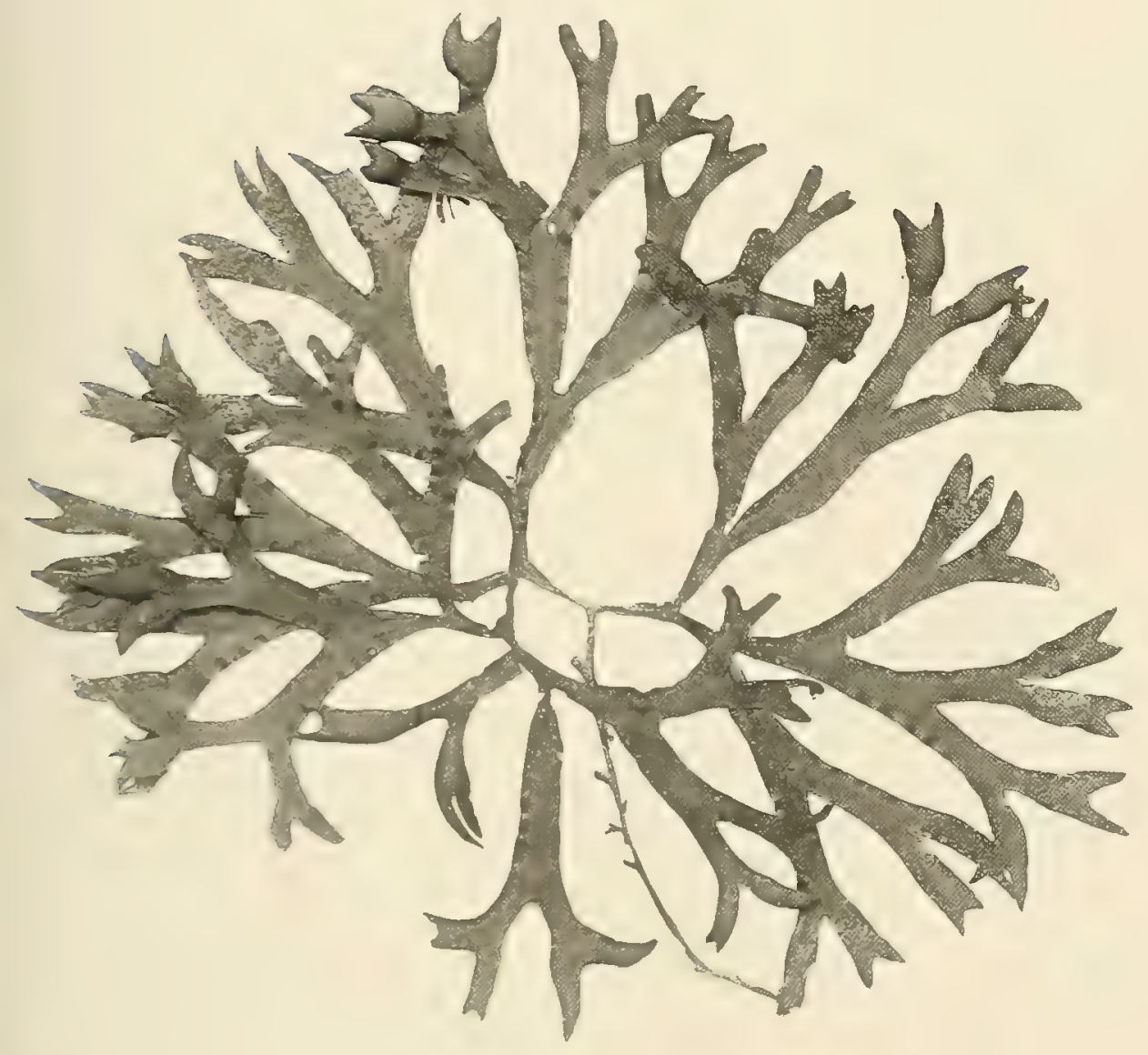


PLATE :

Fucus furcatus $\mathbf{f}$. elongatus Gardner

From a lhotograph of the type specimen. One-third natural size. 


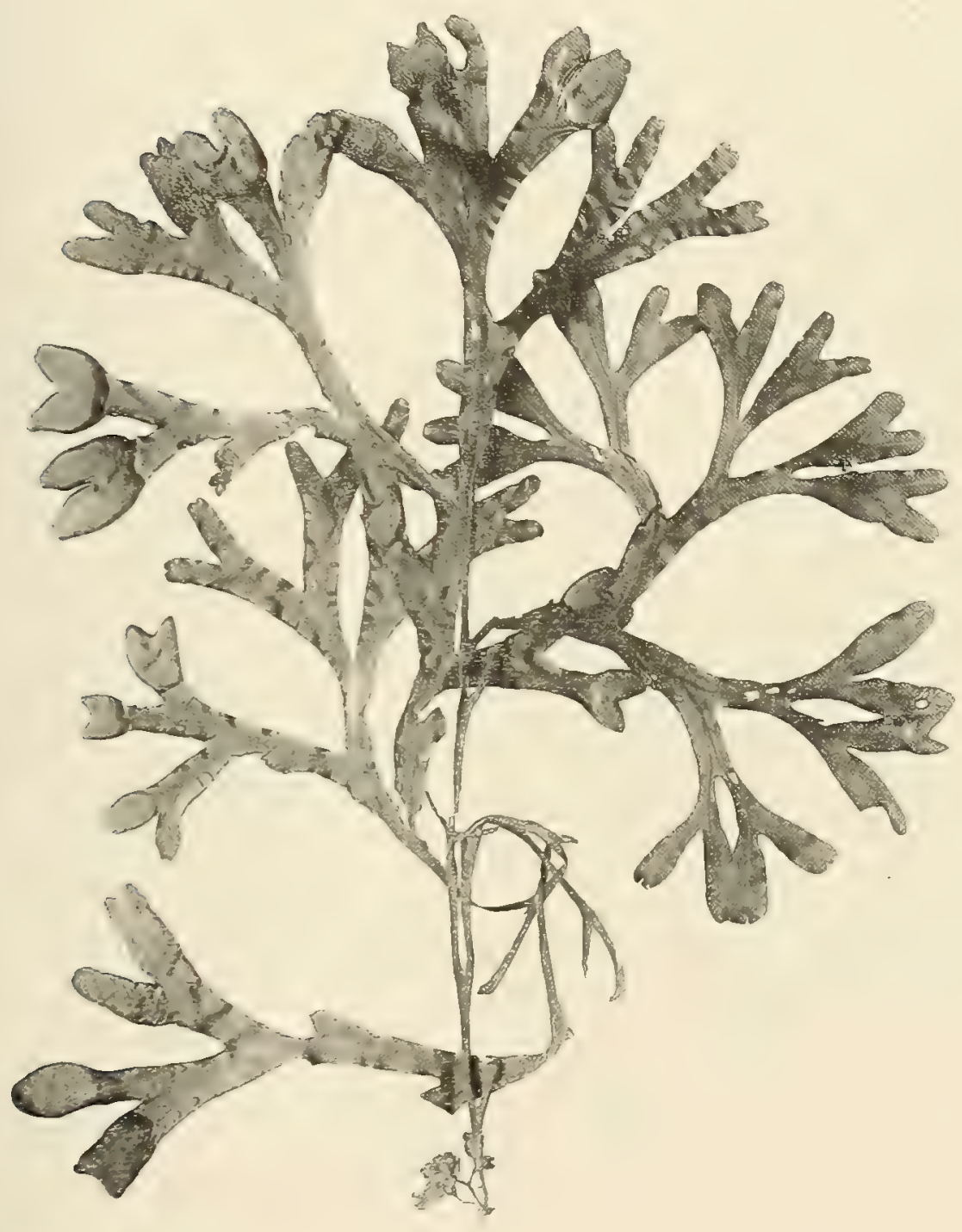




\section{PLATE 10}

Fucus furcatus $f$. Tuxurians Gardner

From a pliotograph of the type specimen, a young plant fruiting for the first time, showing many sterile terminal segments. One-third natural size. 


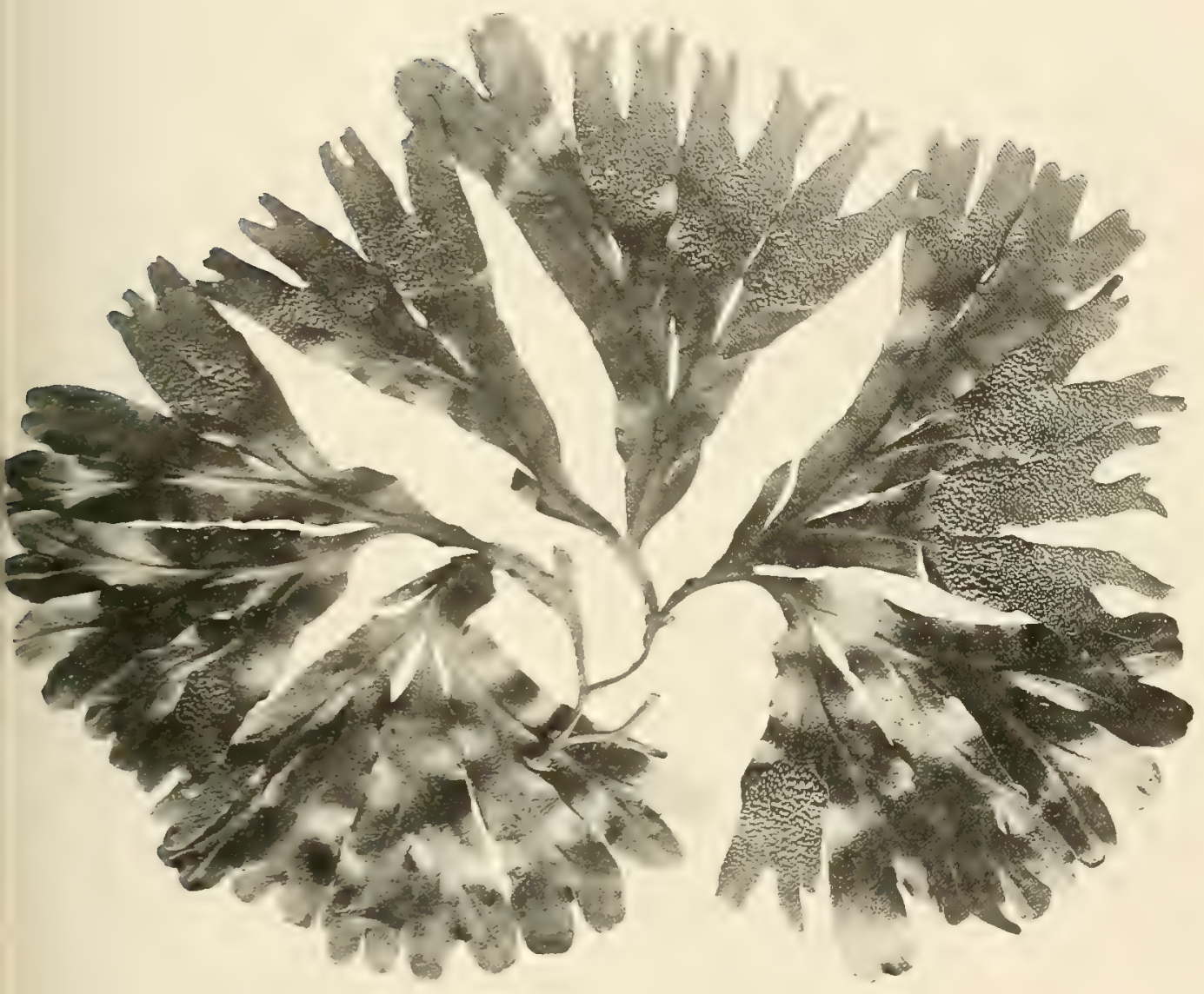


PLATH 11

Fucus furcatus $\mathbf{f}$. reflexus Gardner

From a photograph of the type specimen. Two-fifths natural size. 


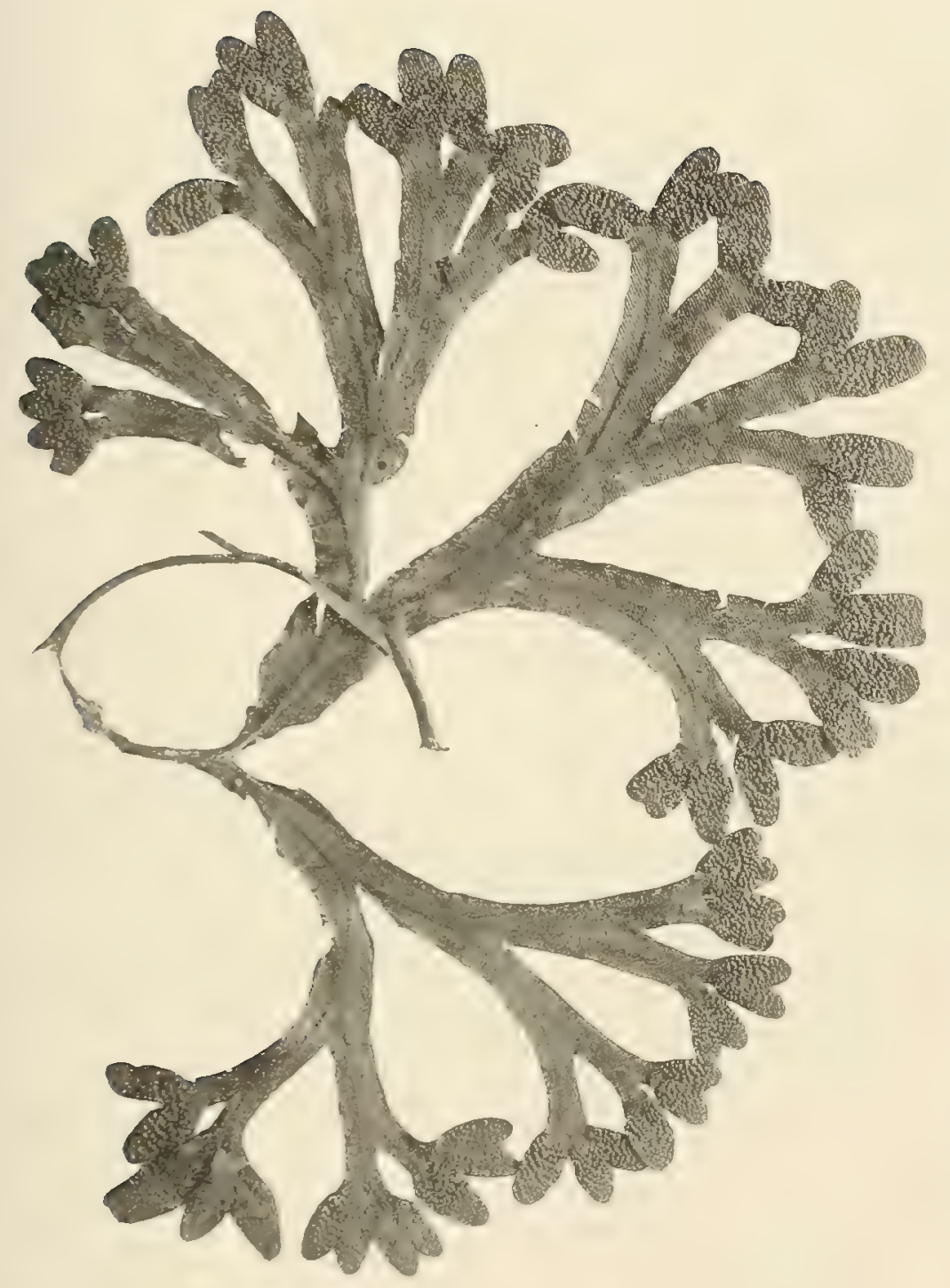


PLATE 11a

Fucus fureatus $\mathrm{f}$. reflerus Gardner

From a photograpli of a cotype specimen showing some sterile segments. Two-fifths natural size. 


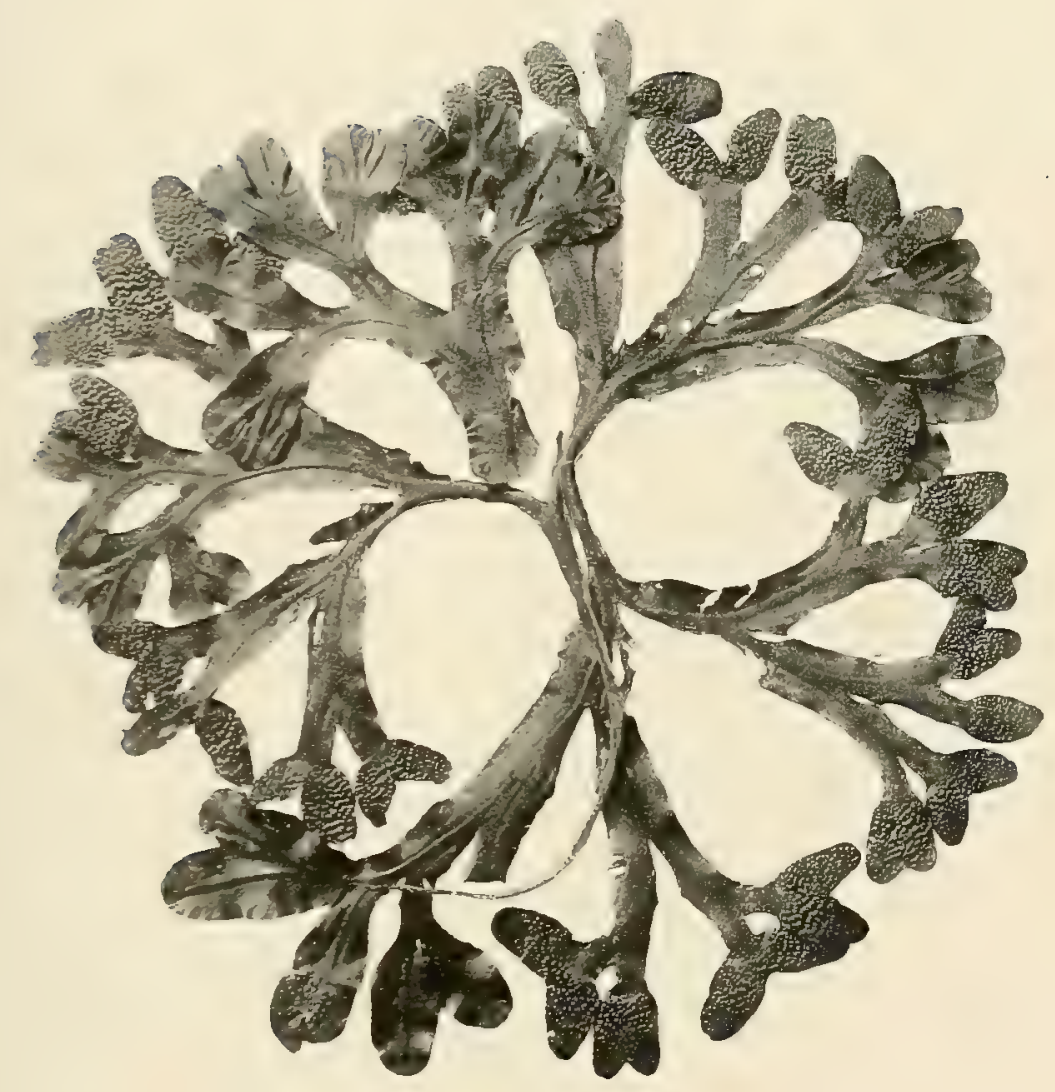


PLATE 12

Fucus furcatus fo refexus Gardner

From a photogxaph of a sterile cotype specimen. Two-fifths natural size. 


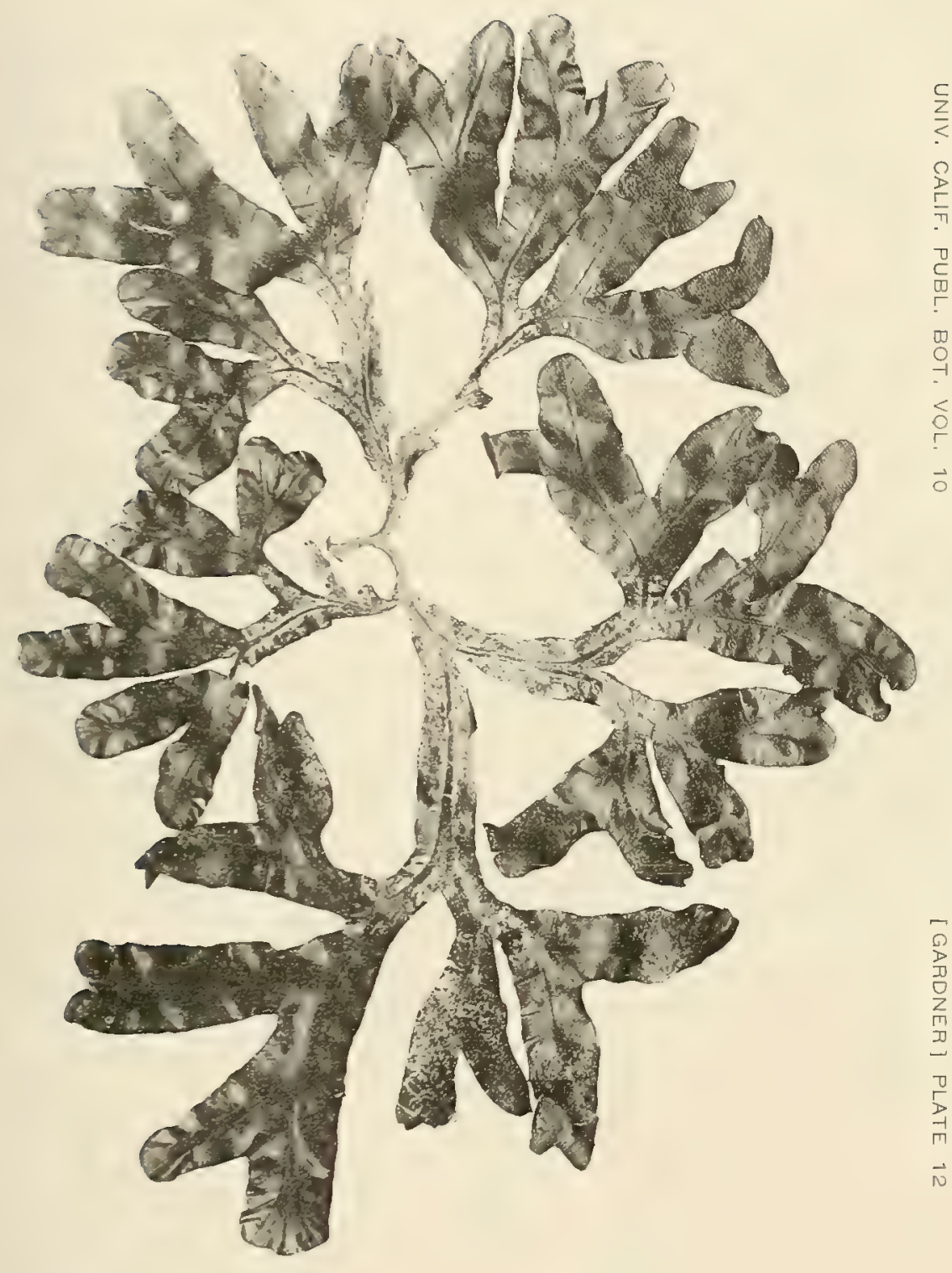


PLATE 13

Fucus furcatus f. rigidus Gardner

From a photograph of the type specimen. One-third natural size. 



\section{PLATE 14}

Fucus furcatus f. latifrons Gardner

From a photograph of the type specimen, a young plant just hegiuning to fruit. Two-fifths natural size. 


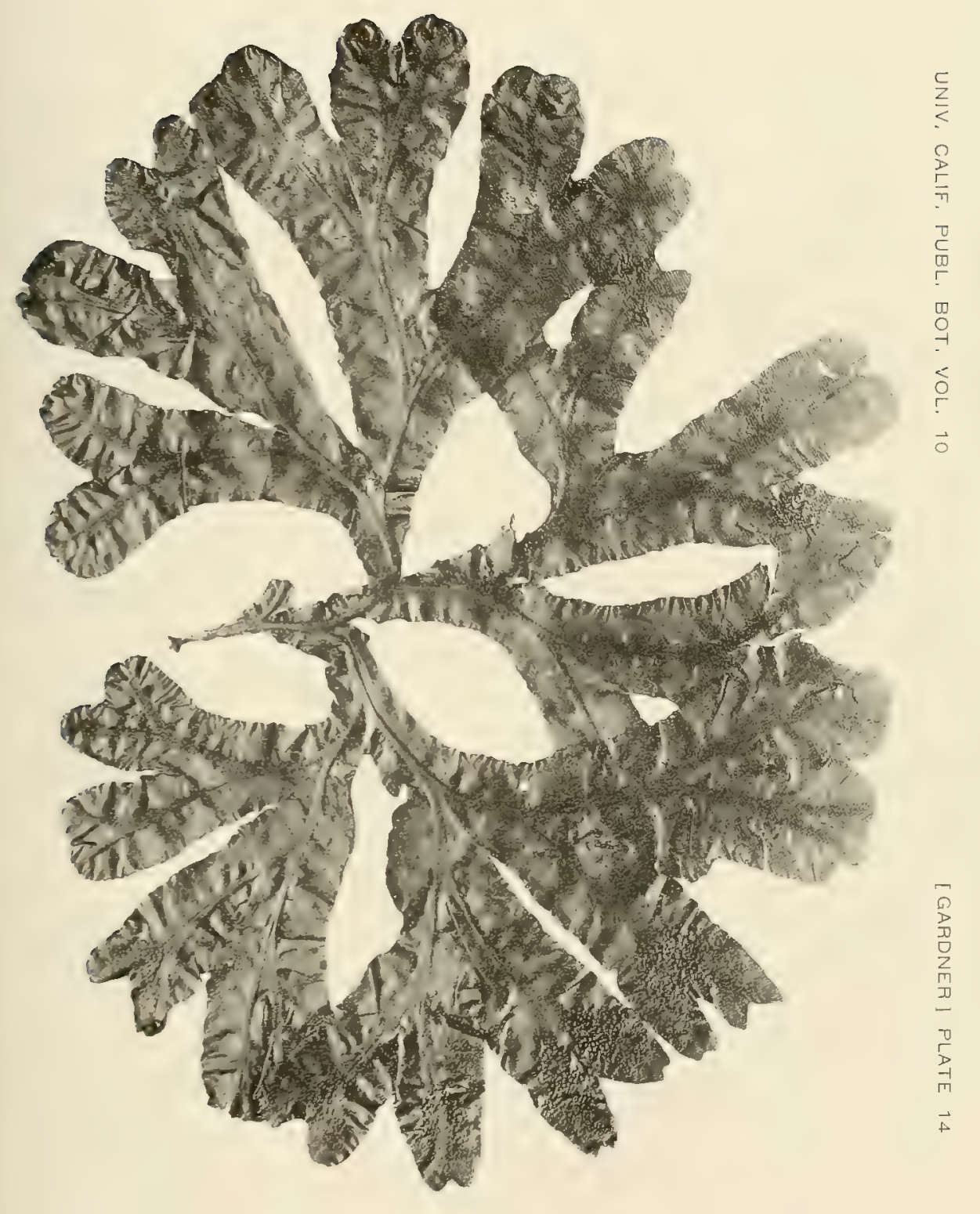


PLATE 15

Fucus furcatus $\mathrm{f}$. contortus Gardner

From a photograph of parts of two dried plants. One-third natural size. 


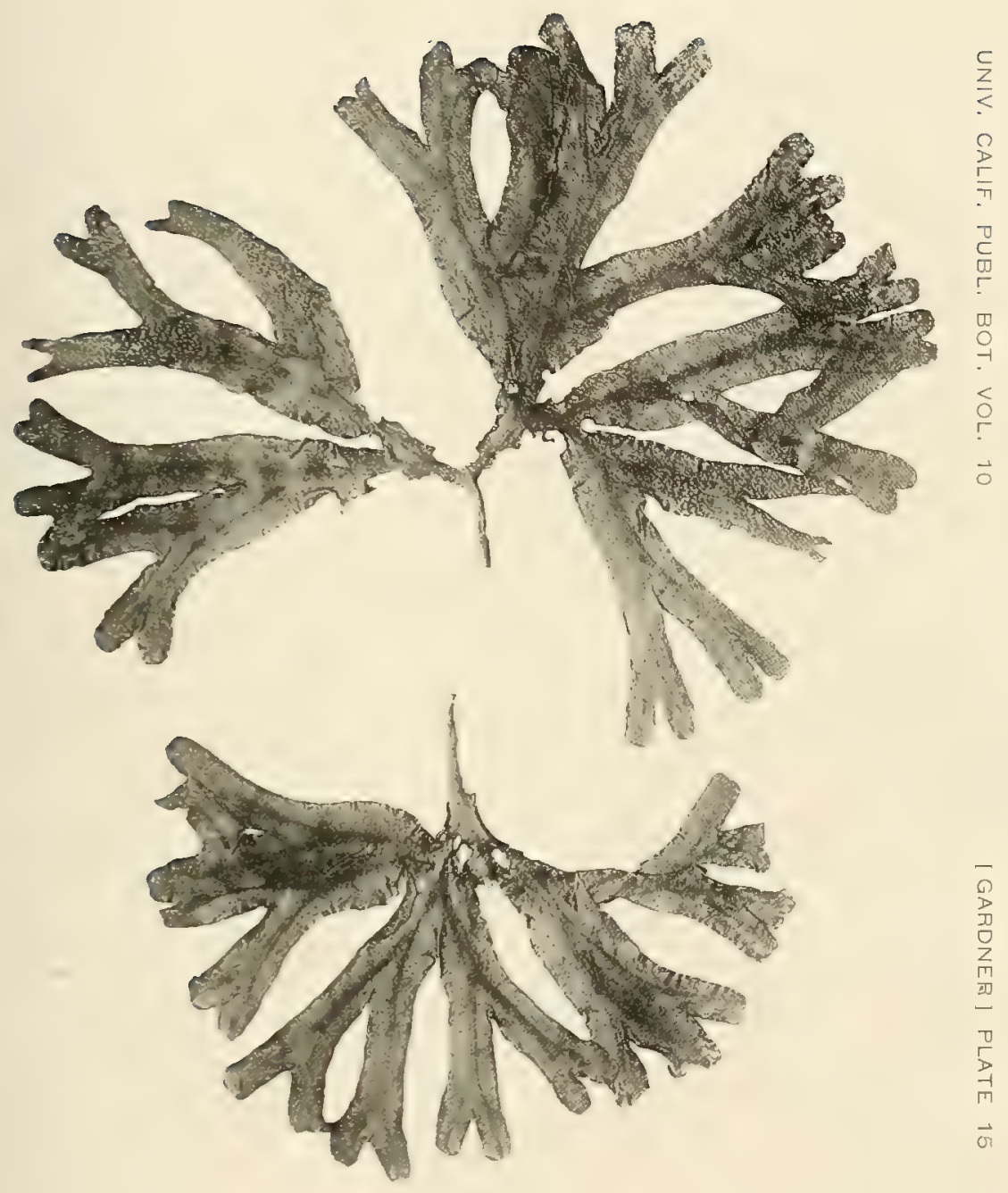


PLATE 16

Fucus furcatus f. variabitis Gardner

From a photograph of a variety of forms of receptacles. One-half natural size. 


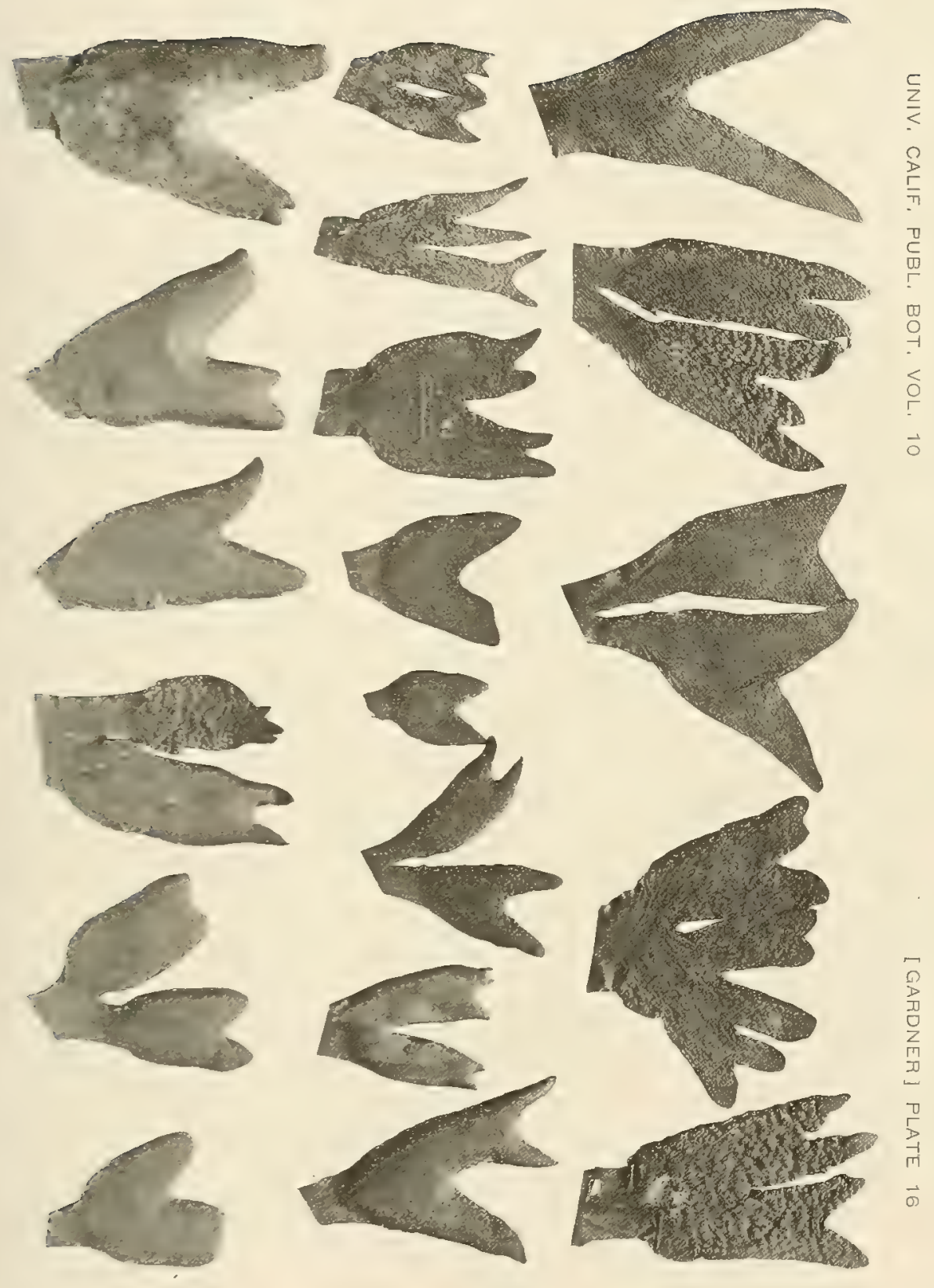




\section{PLATE 17}

Fucus furcatus f. variabitis Gardner

From a photograph of a portion of the type specimen. Two-fifths natural size. 


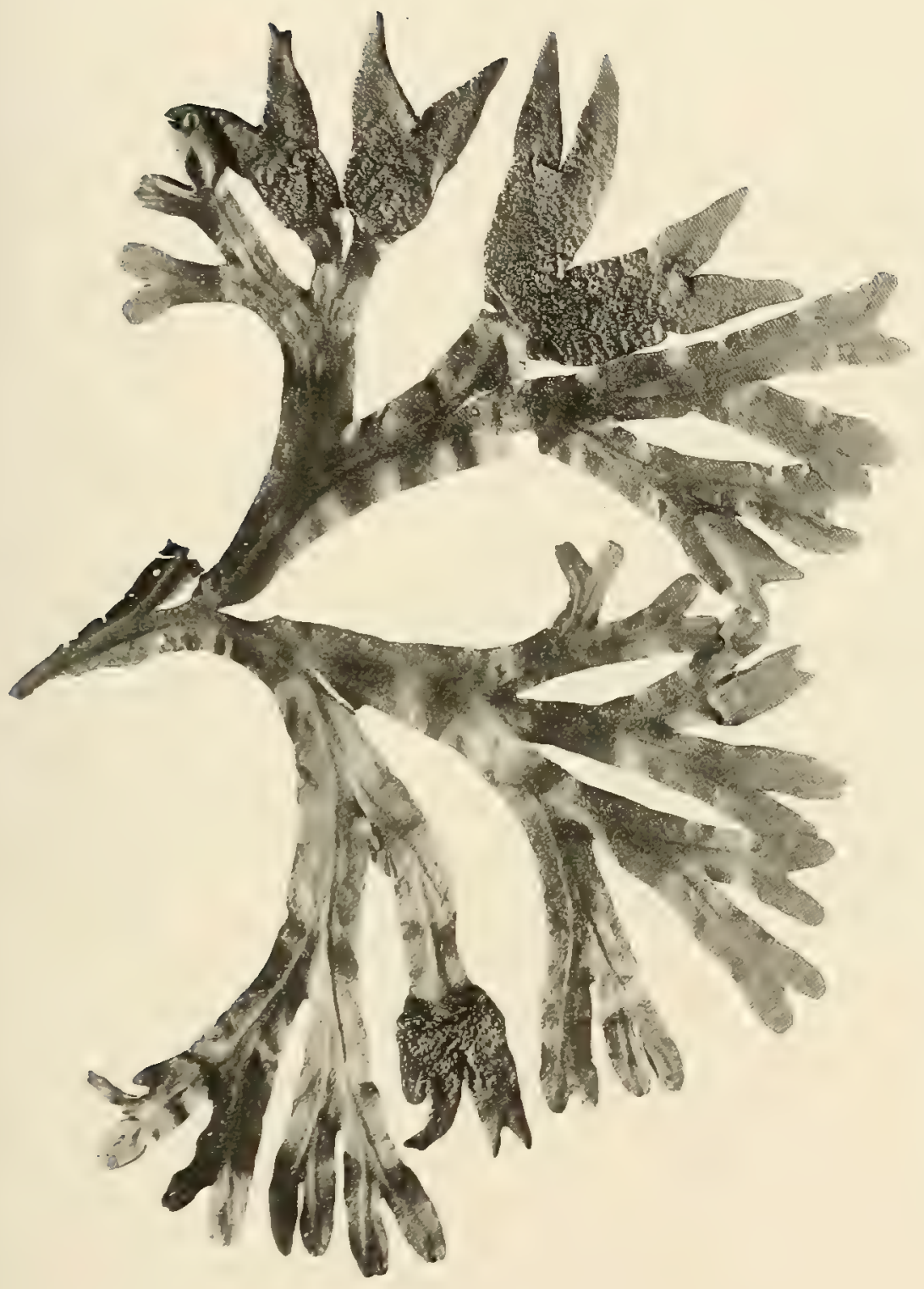

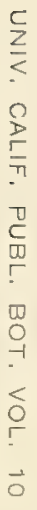

7
8
0
0
2
0
0
0
0
5
-1
7
7
2 


\section{PLATE 18}

Fucus nitens Gardner

From a photograph of a young plant with a few fruiting segments and characteristic vegetative segments. One-half natural size. 
PLATE 19

Fucus witens Garimer

From a photograph of the type specimen showing mature receptacles, mostly swollen. Two-fifths natural size. 


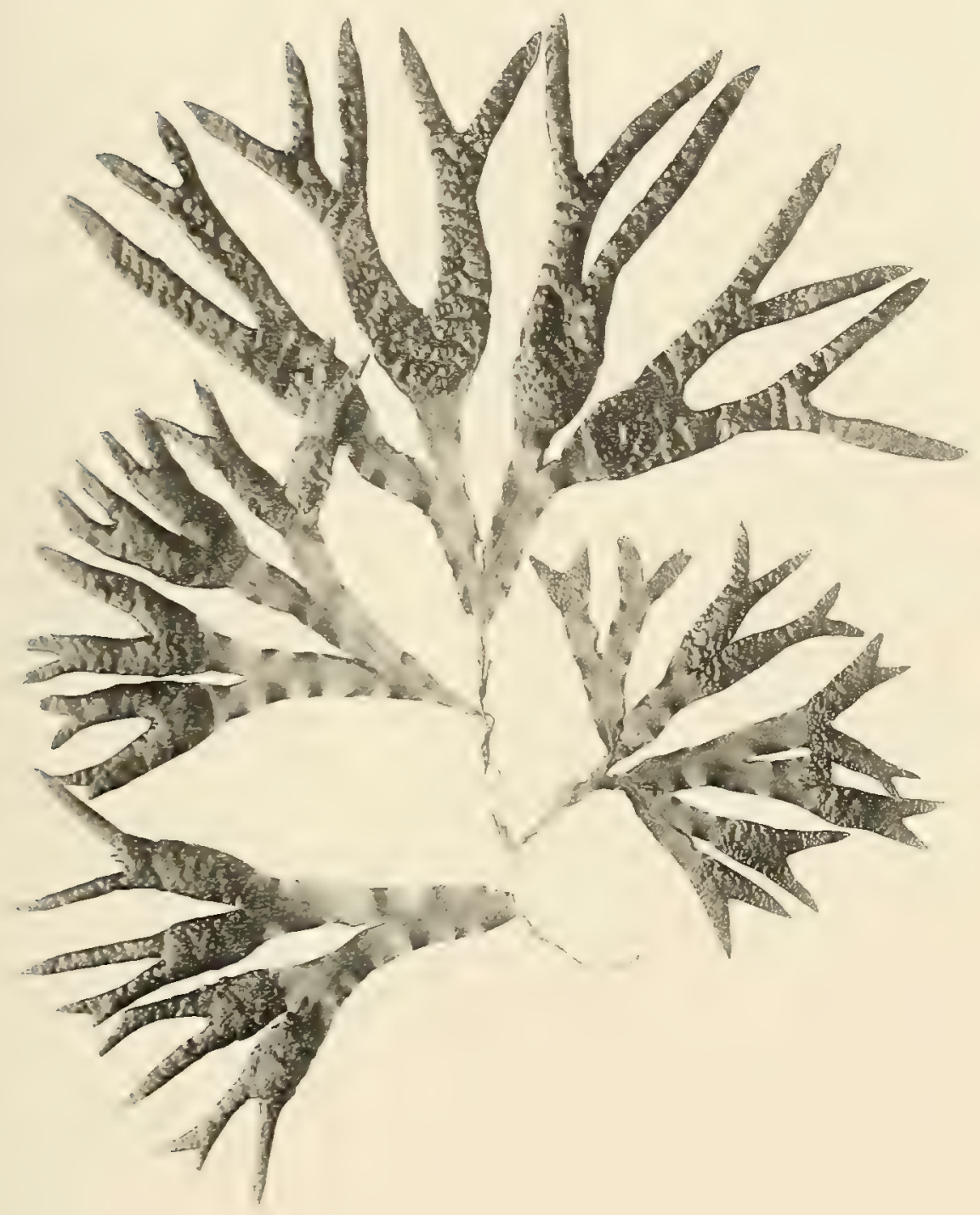




\section{PLA T'E 20}

Fucus inflatus f. edentatus (De la Pyl.) Rosenv.

From a photograph of a plant from the Faeröe Islands, determined by Börgesen. One-third natural size. 


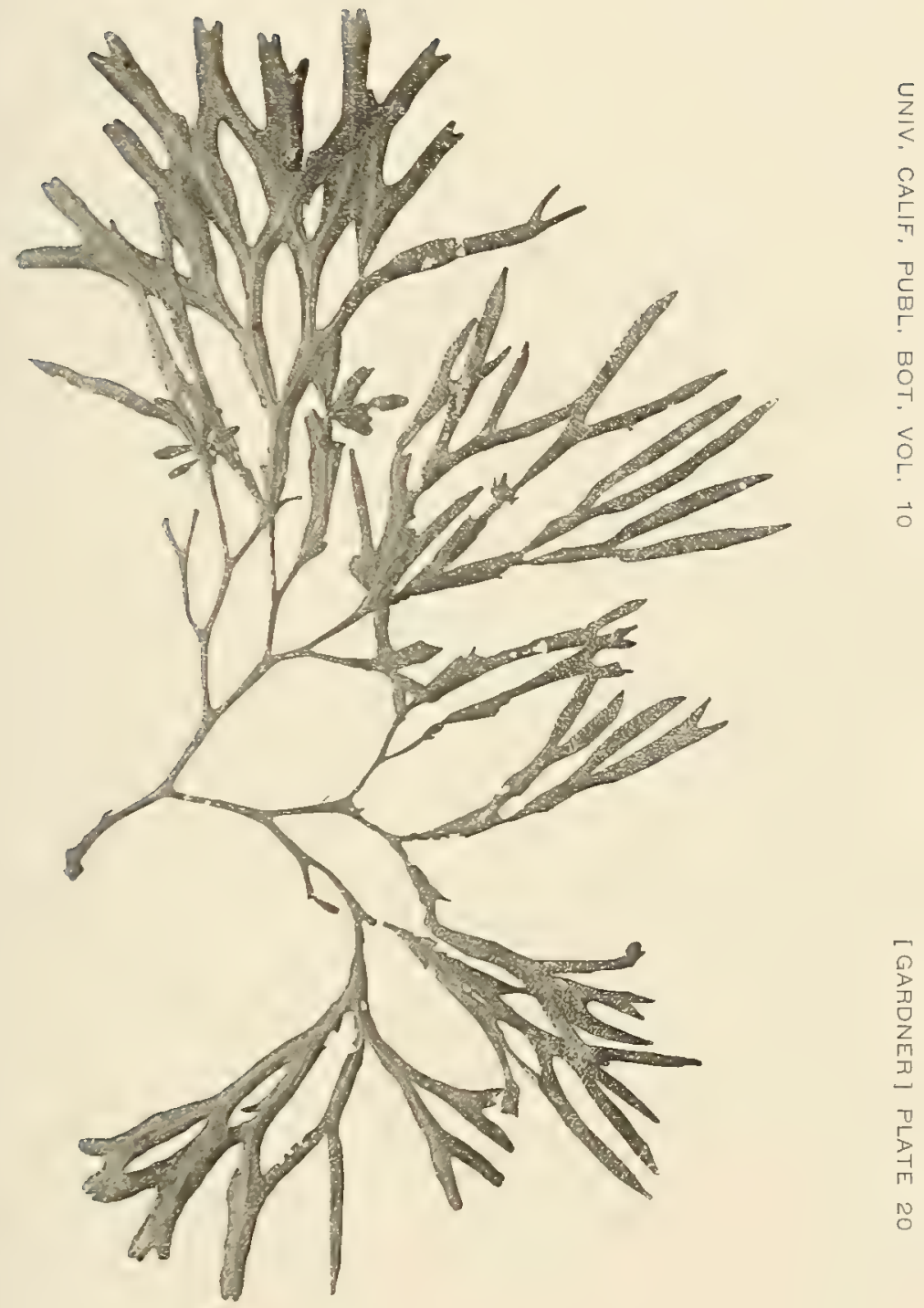


PLATE 21

Fucus edentatus f. hesporius Garther

From a photograph of a portion of a plant, the type. One-third natural size. 


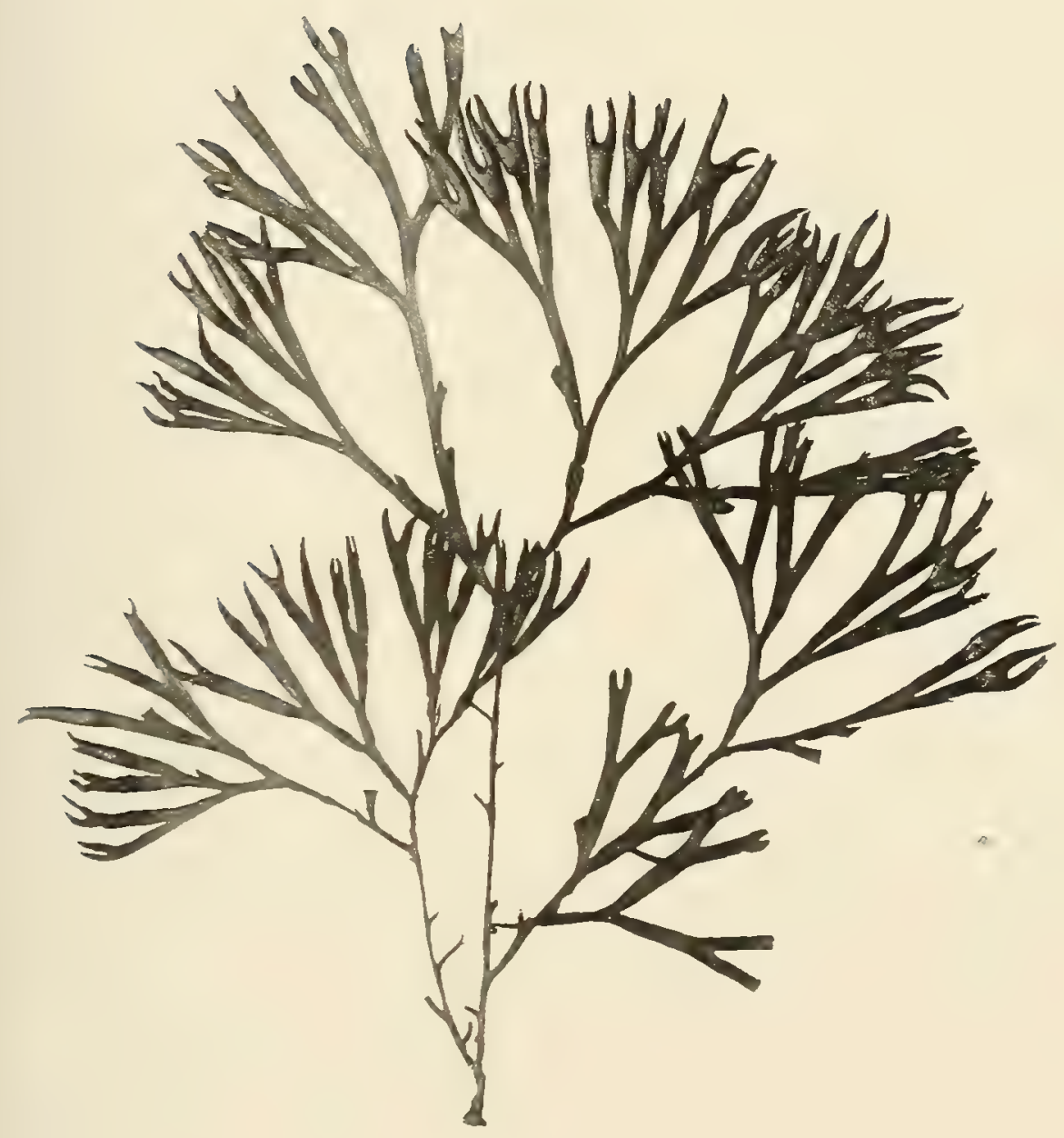


PLATE 22

Fucus edentatus f. divergens Gardner

From a photograph of the type specimen. Three-eighths natural size. 

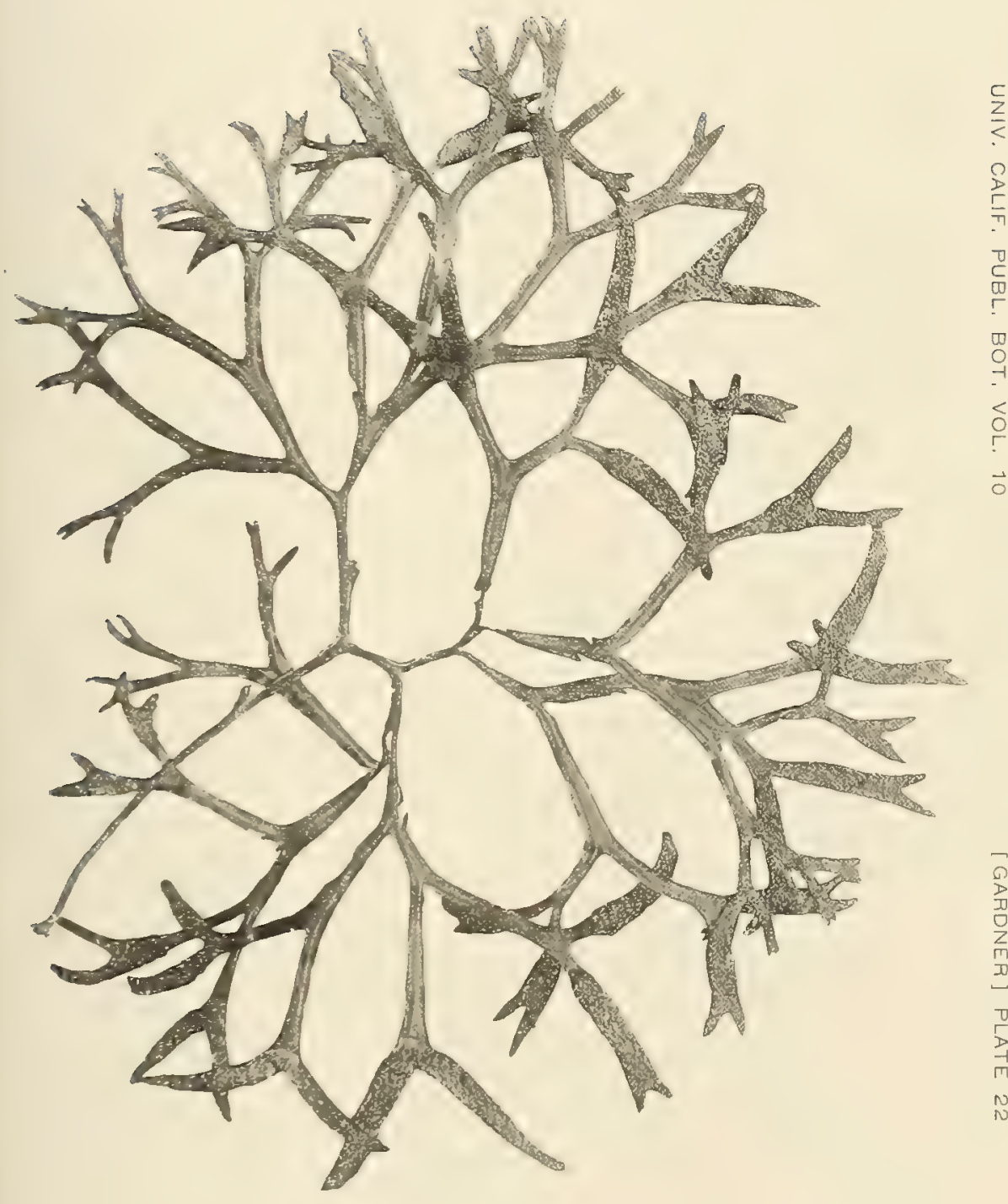


\section{PLATE 23}

Fucus edentatus f. costatus Gardner

From a photograph of the type specimen. Two-fifths natural size. 


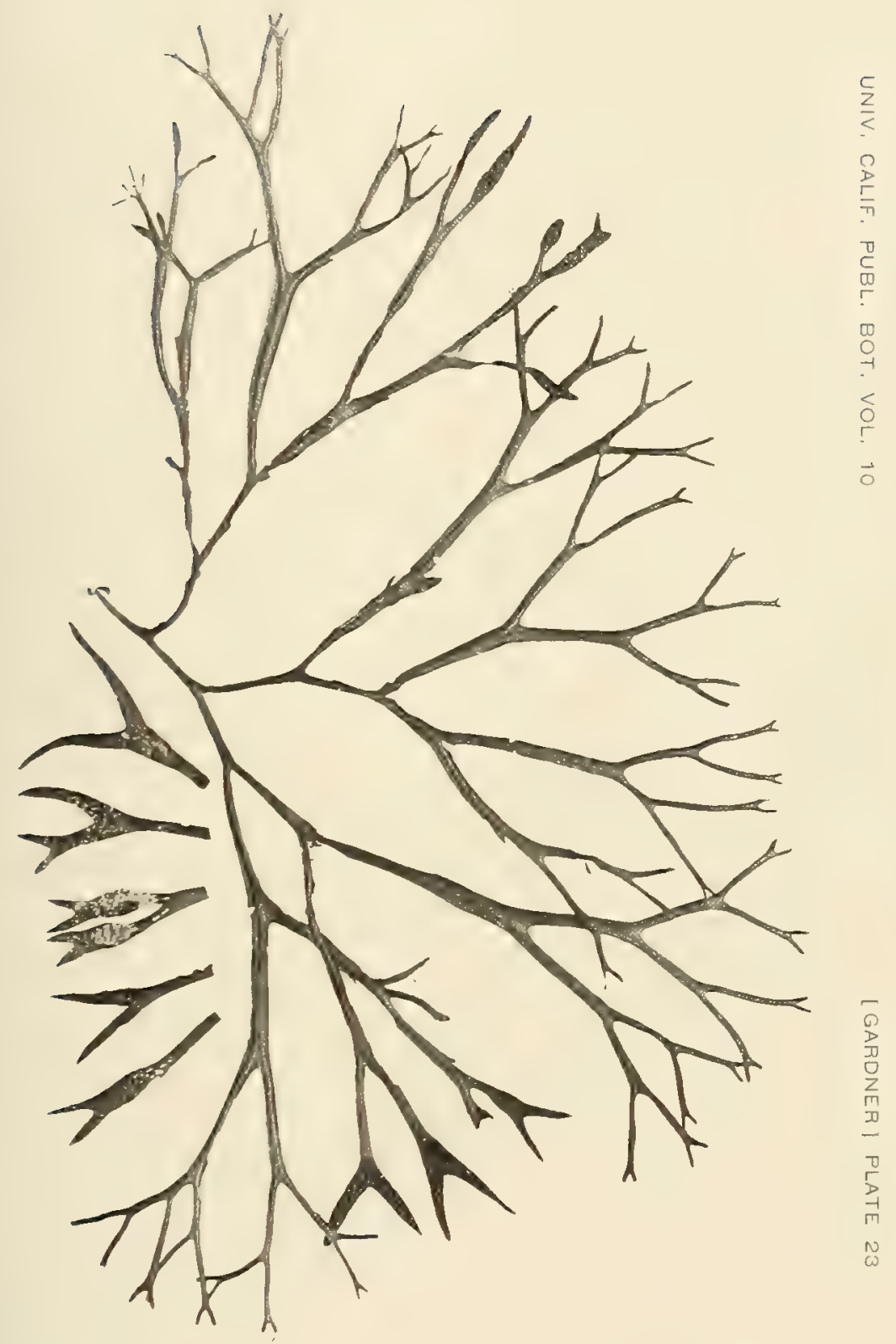


PLATE 24

Furus edentatus f. costatus Gardner

From a photograph of two plants, the smaller completely ancl the larger almost sterile. Two-fifths natural size. 
PLA TE 25

Fucus edentatus f. acutus Gardner

From a fhotongly of a plant. Two-fifths natural sime. 


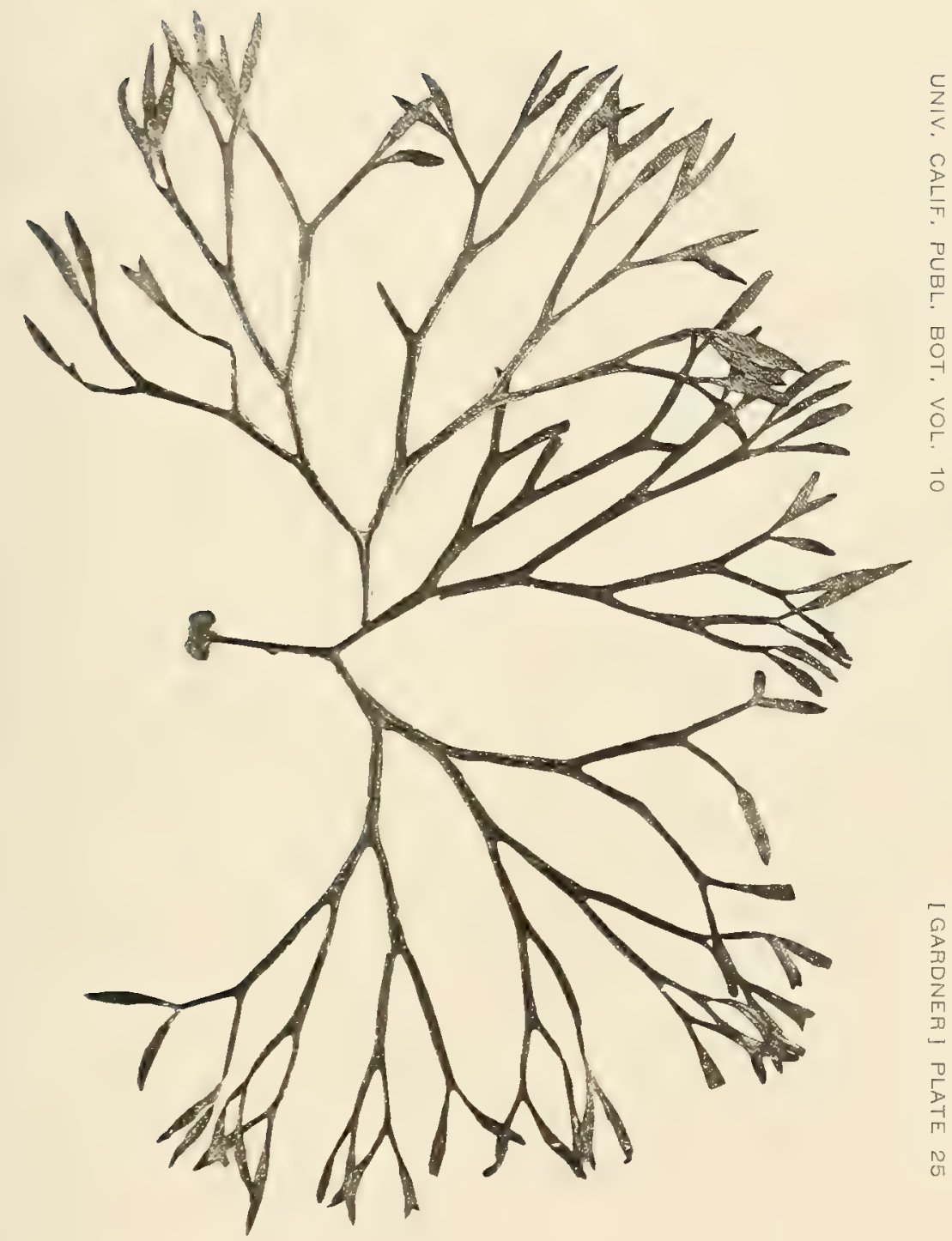


PLATE 26

Fucus edentatus $\mathbf{f}$. divaricatus Gariner

From a photograph of a fruiting plant. Three-fifths natural size. 


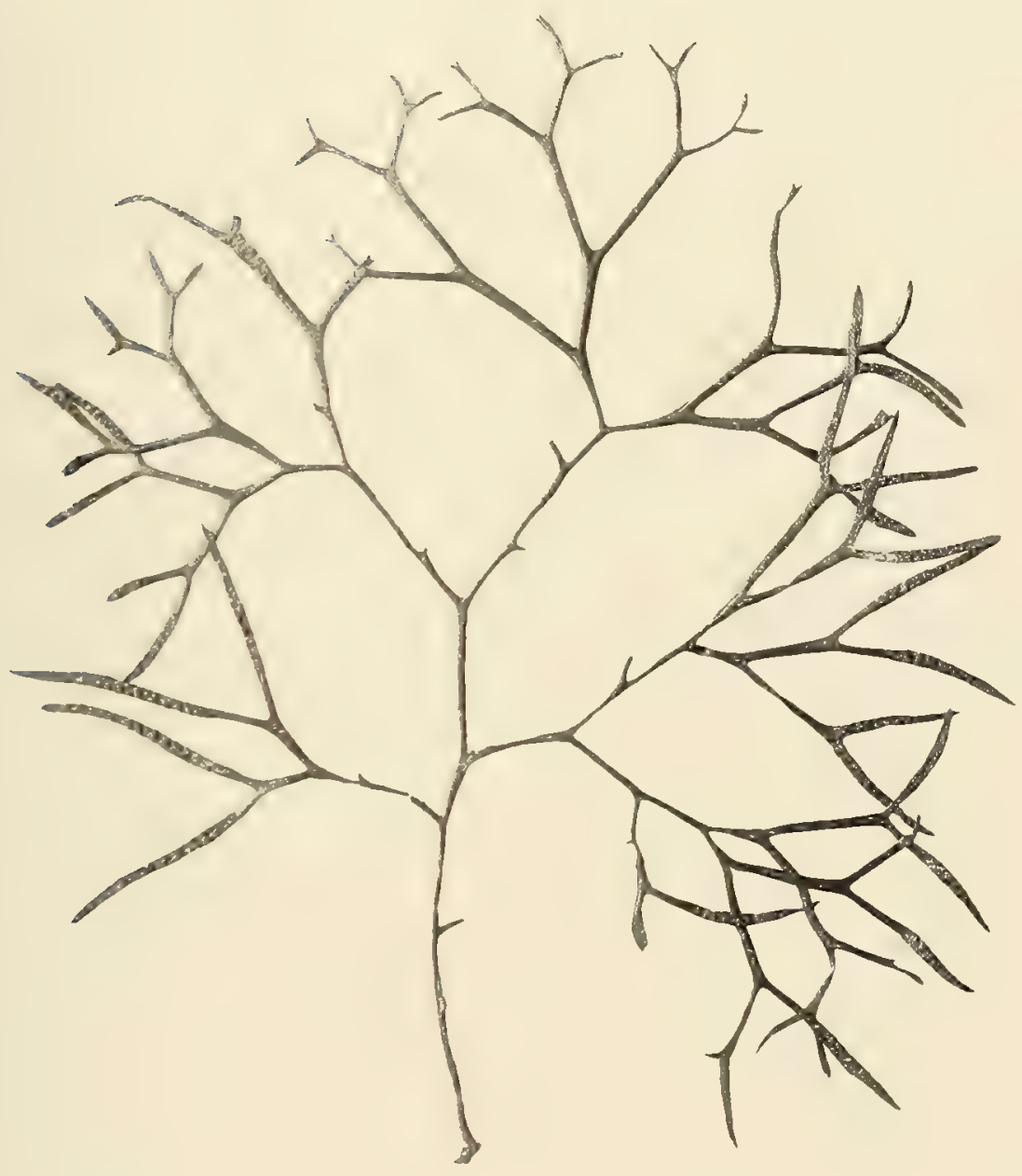


PLATE 27

Fucus membranaceus f. abbreviatus Gardner

From a jhotograph of one-half of a plant, the type. Two-thiris natural size. 


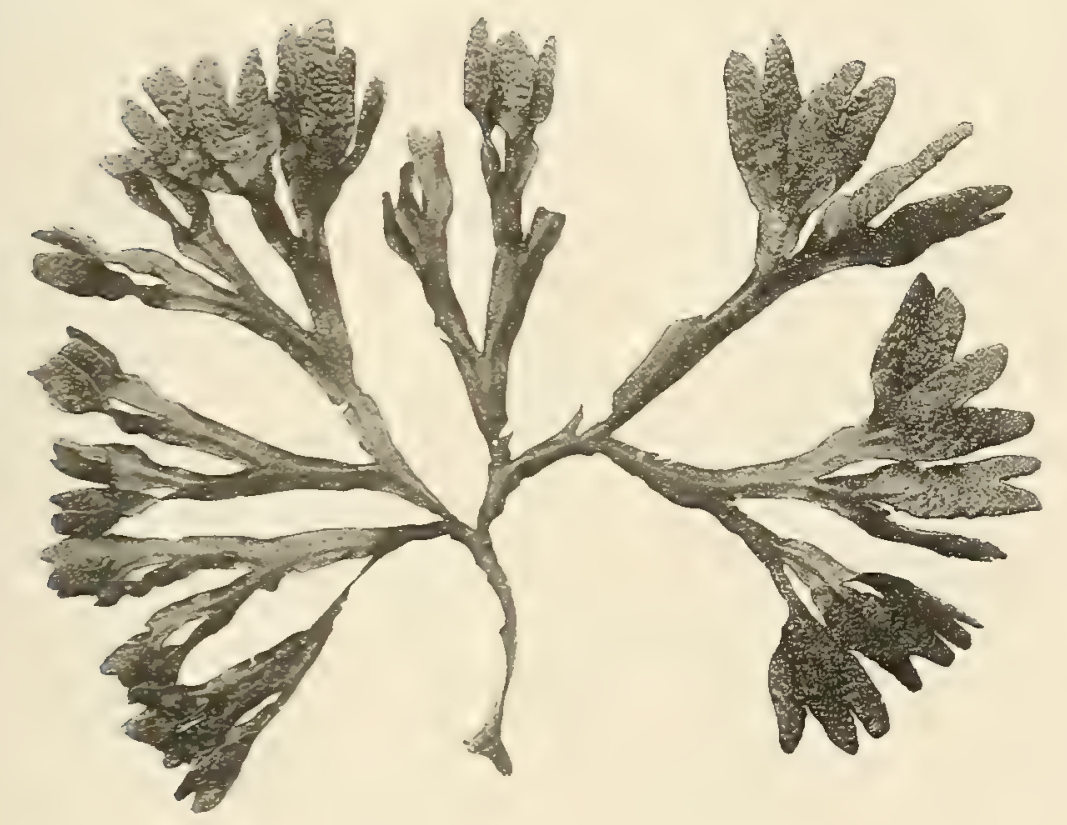


PLATE 28

Fucus membranaceus f. acuminatus Gardner

From a photograph of the type specimen. One-half natural size. 


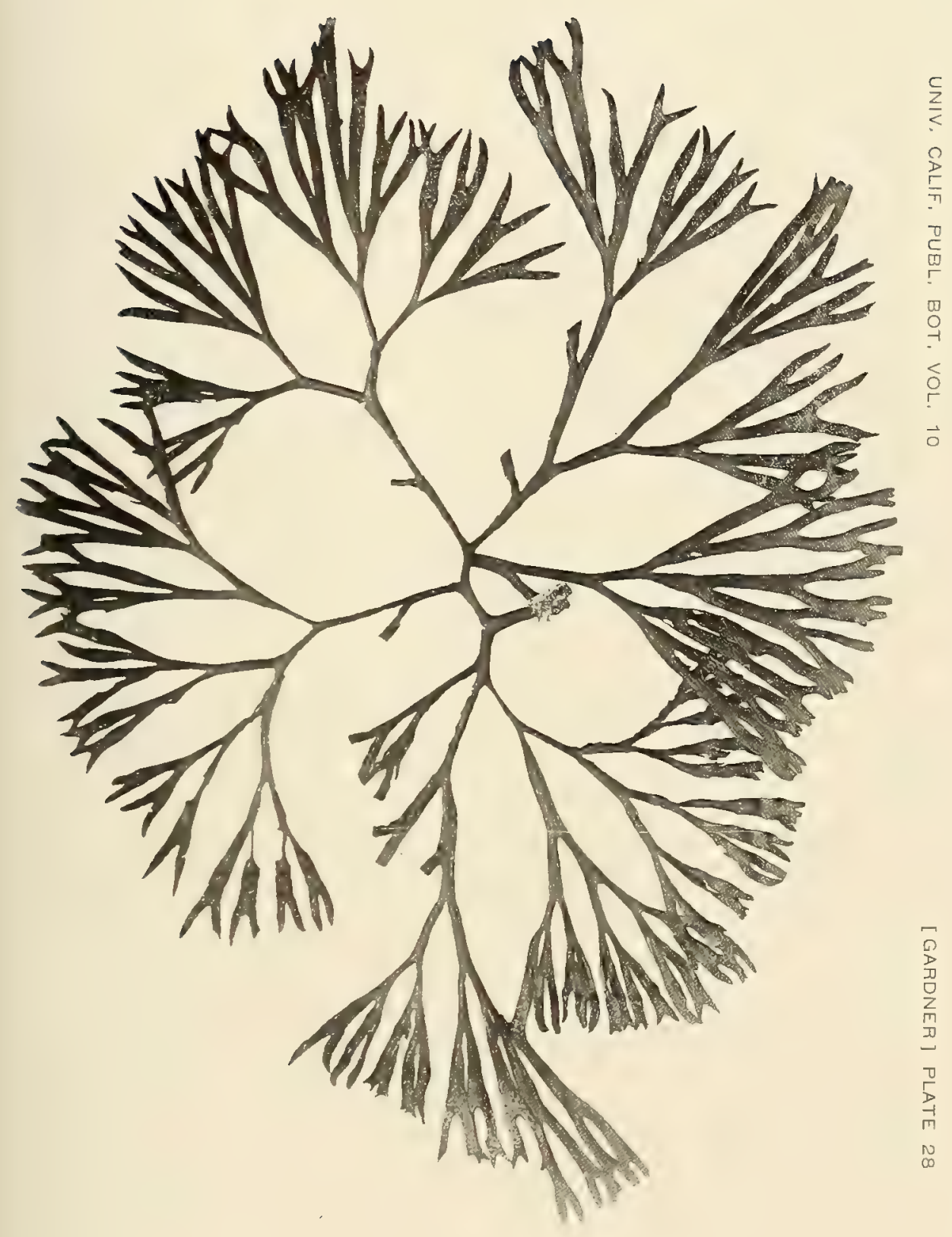


PLATE 29

Fucus membranaceus f. obtusus Gardner.

From a photograph of the type specimen. One-third natural wize. 


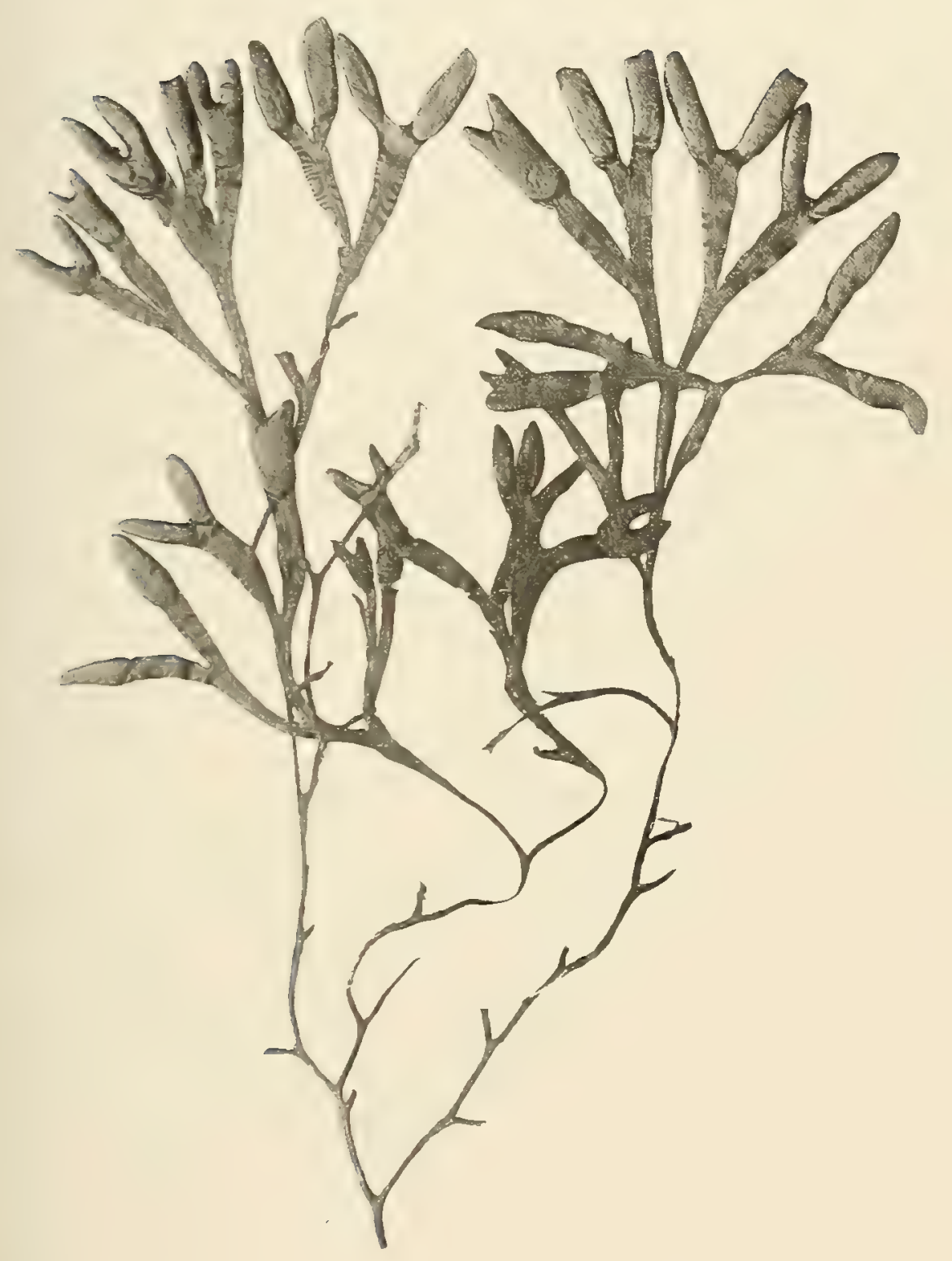


PLATE 30

Fucus membranaceus f. typicus Gardner

From a photograph of a sterile plant of the cotype.

Three-fifths natural size. 


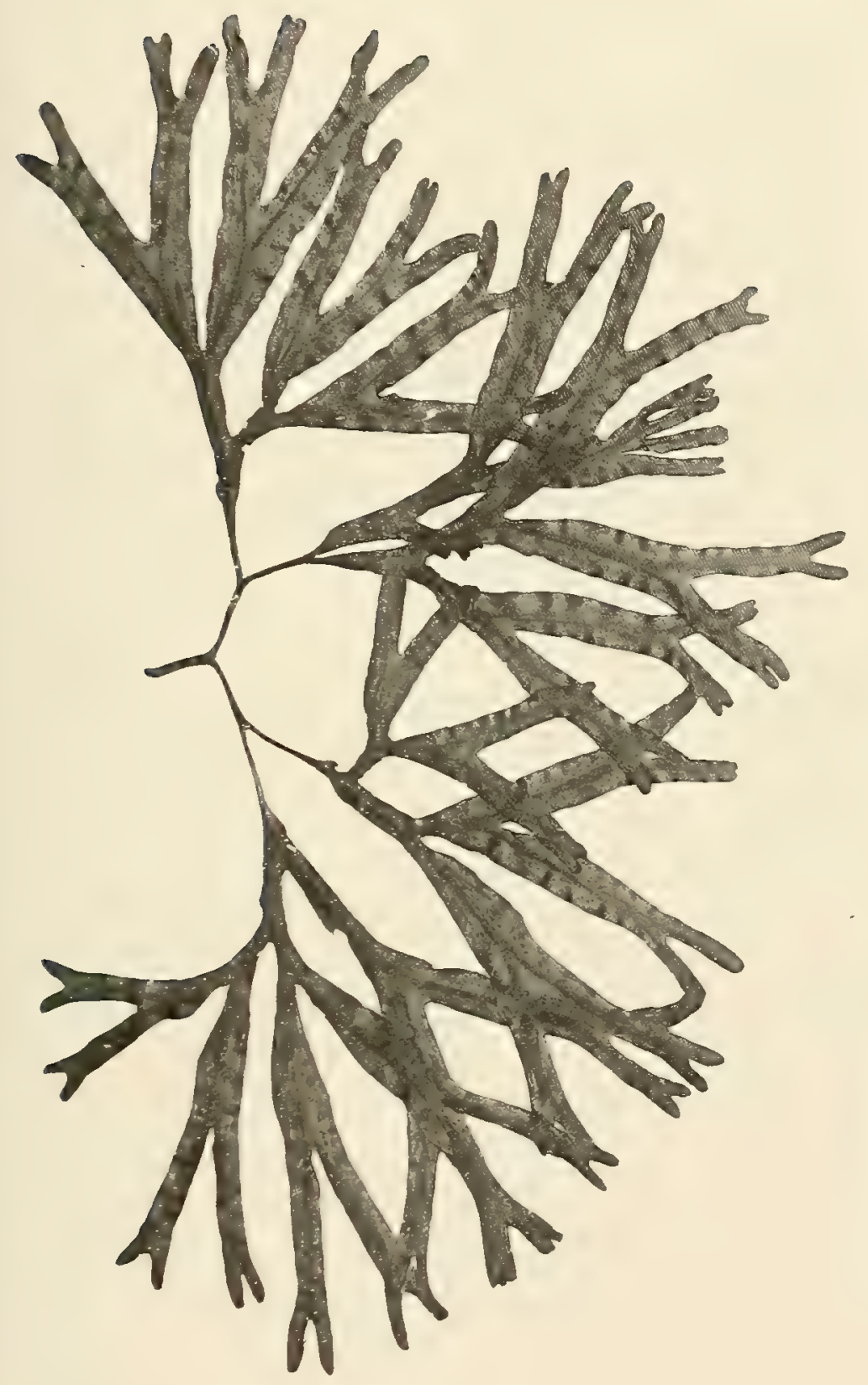

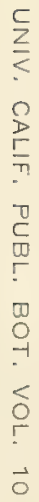

0
2
0
0
2
7
10
2
0
5
7
7
$\omega$
0
0 
PLATE 31

Fucus membranaceus $\mathrm{f}$. typicus Gardner

From a photograph of the type specimen. Three-nfths natural size. 


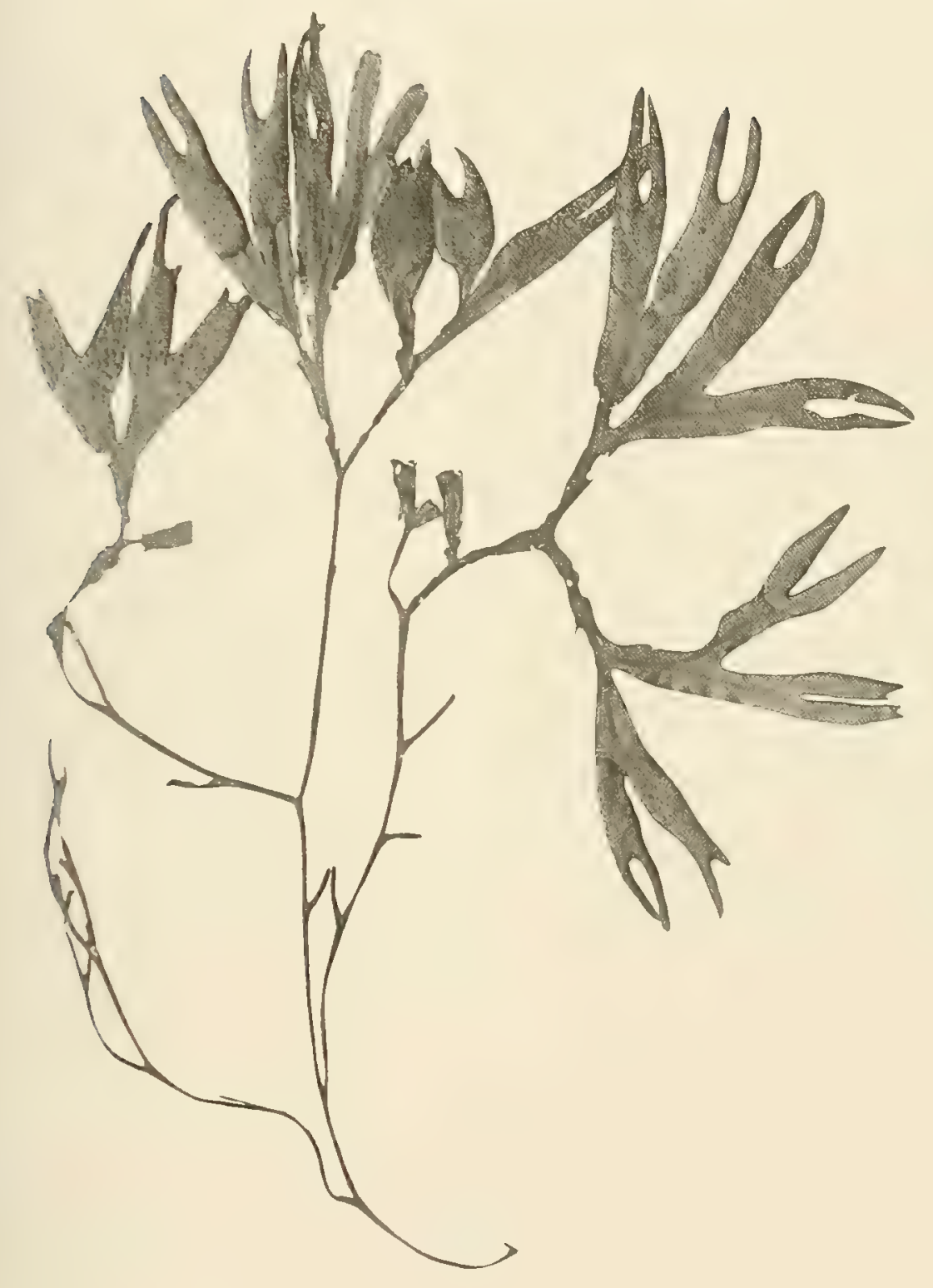


PLATE 32

Fucus membranaceus f. limitatus Gardner

From a photograph of the type specimen. Three-fifths natural size. 


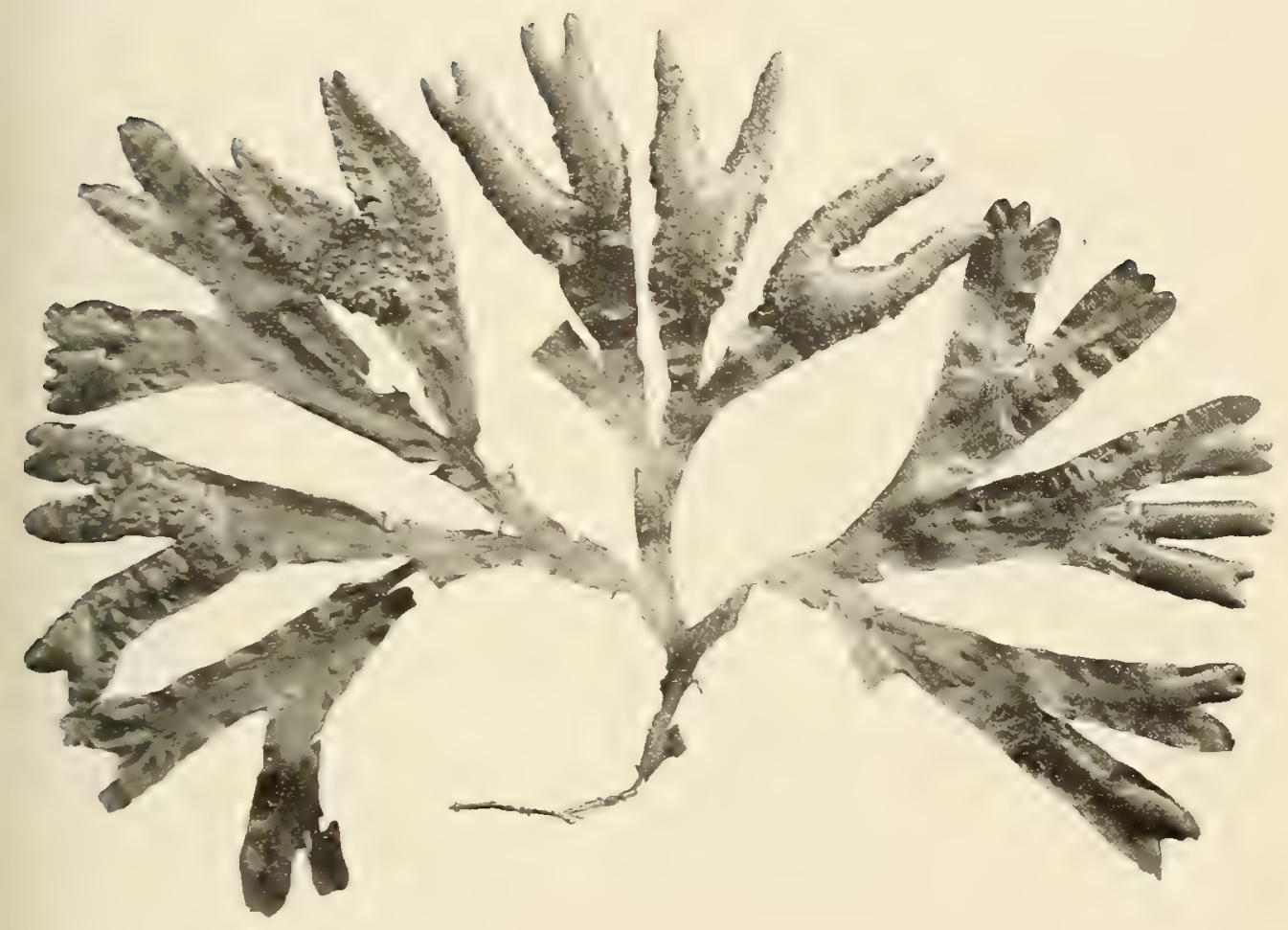


PLATE 33

Fucus membranacens f. latissimus Garlner

From a photograph of portions of plants showing the character of the receptacles and sterile segments. One-third natural size. 


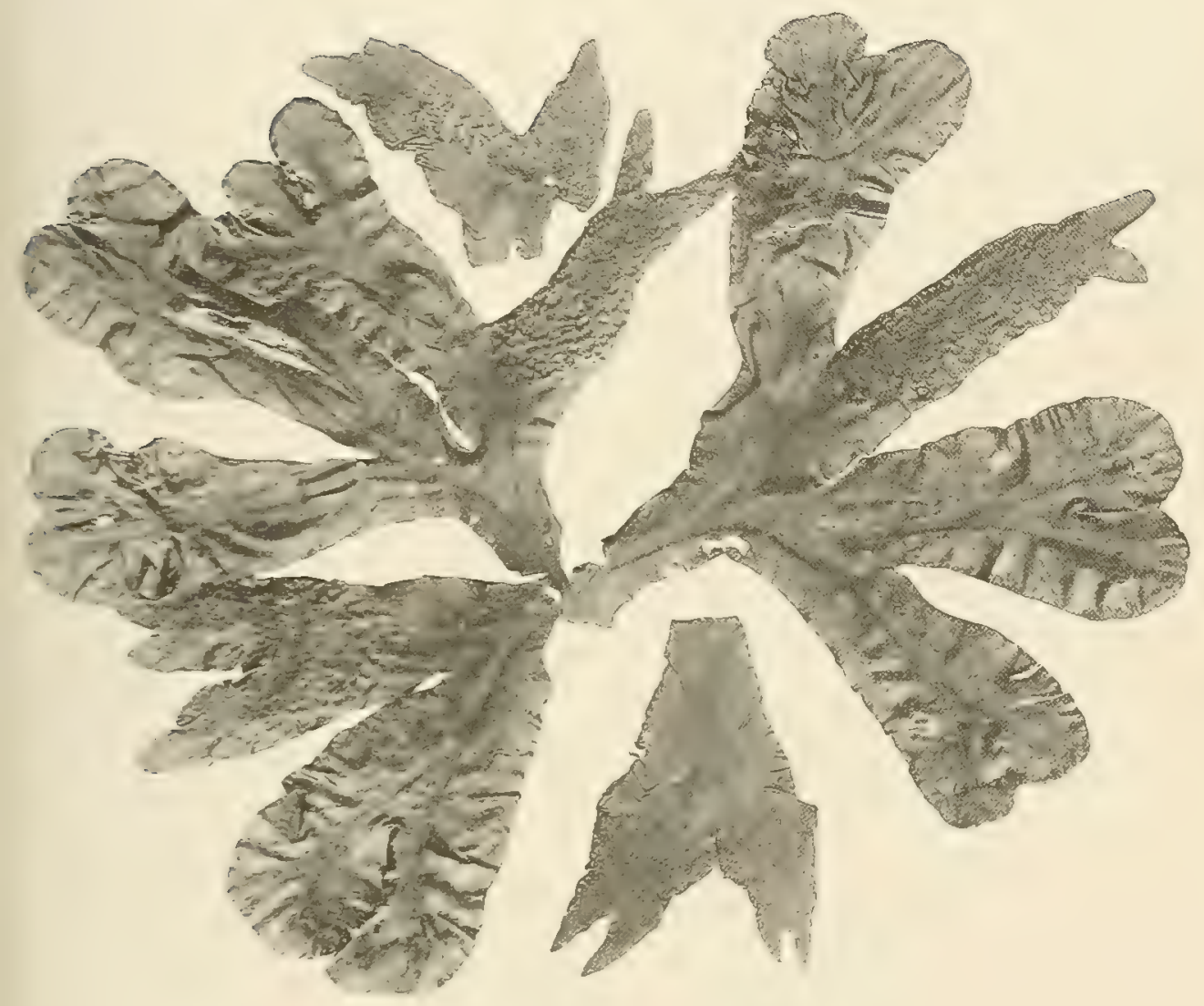


PLATE 34

Fucus membranaceus f. Tatissimus Gardner

From a photograph of the type speeimen. One-third natural size. 


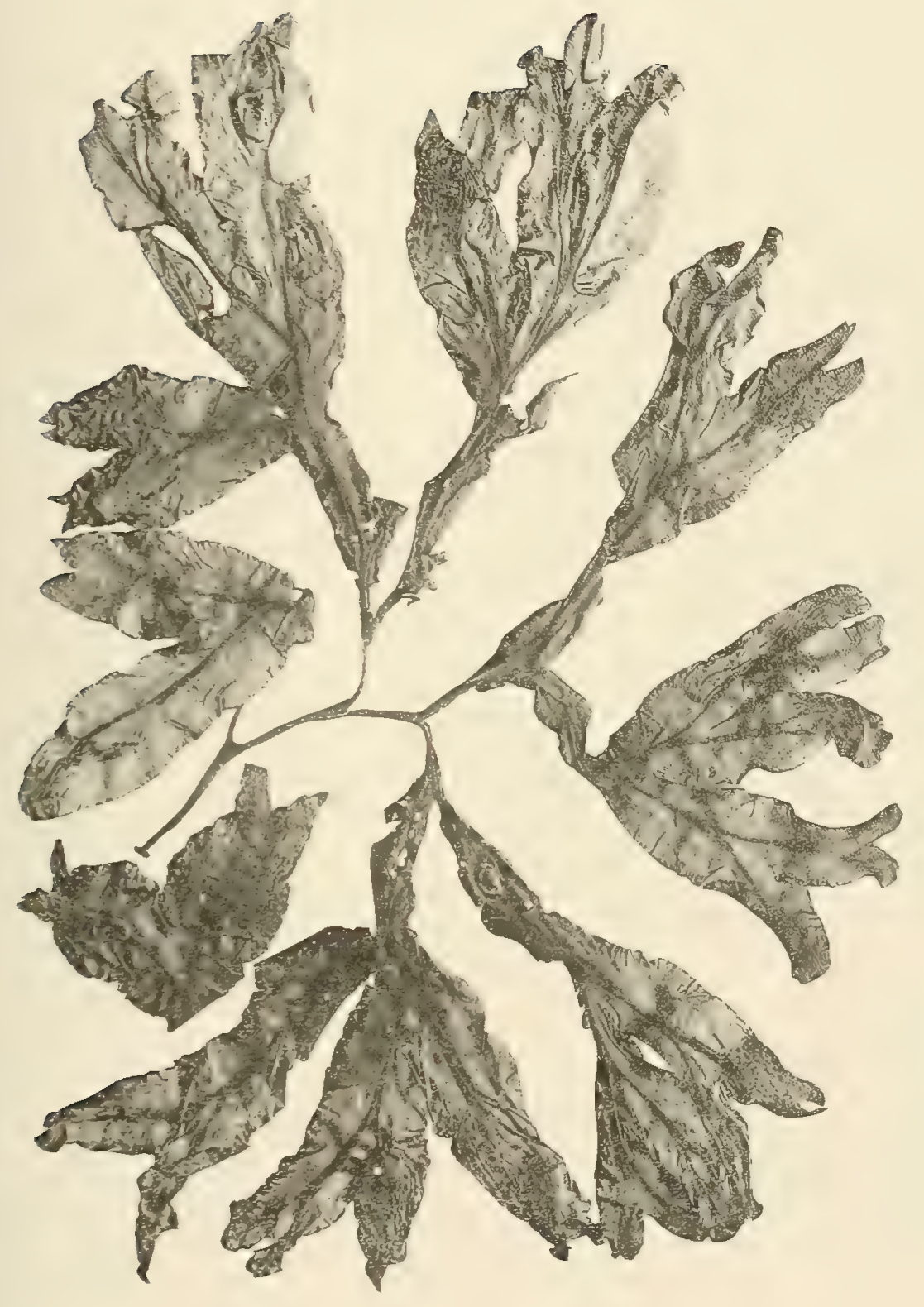

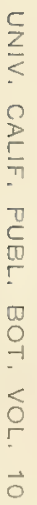

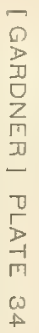


PLATE 3.

Fueus evanescens Ay.

From a photograth of a dried specimen, determined by J. Agardh. 'To-thirds natural size. 


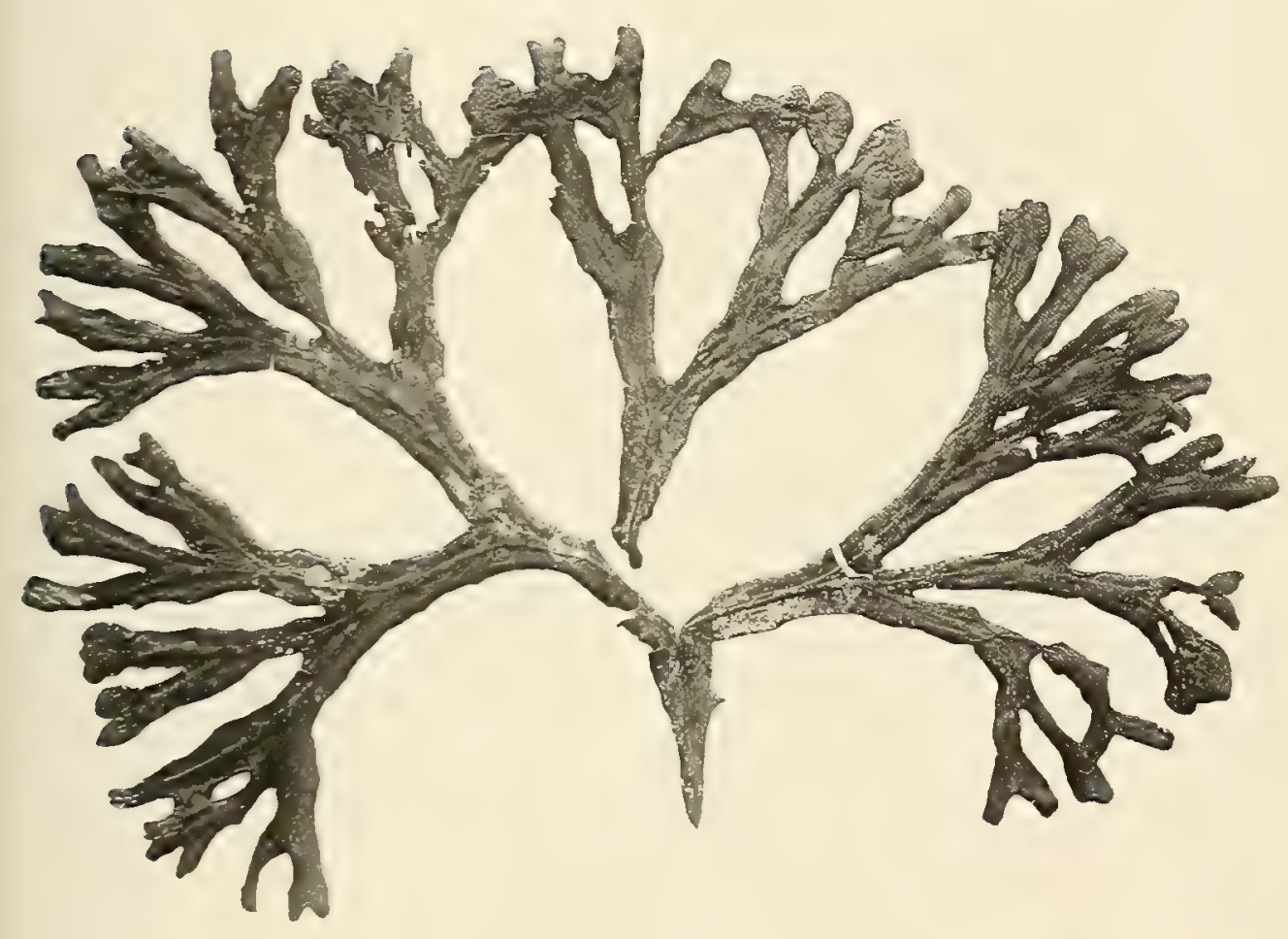


PLATE 36

Fucus evanescens $\mathbf{f}$. pergrandis $\mathbf{K}$ jellm.

From a photograph of fragments of dried plants. Two-thirds natural size. 


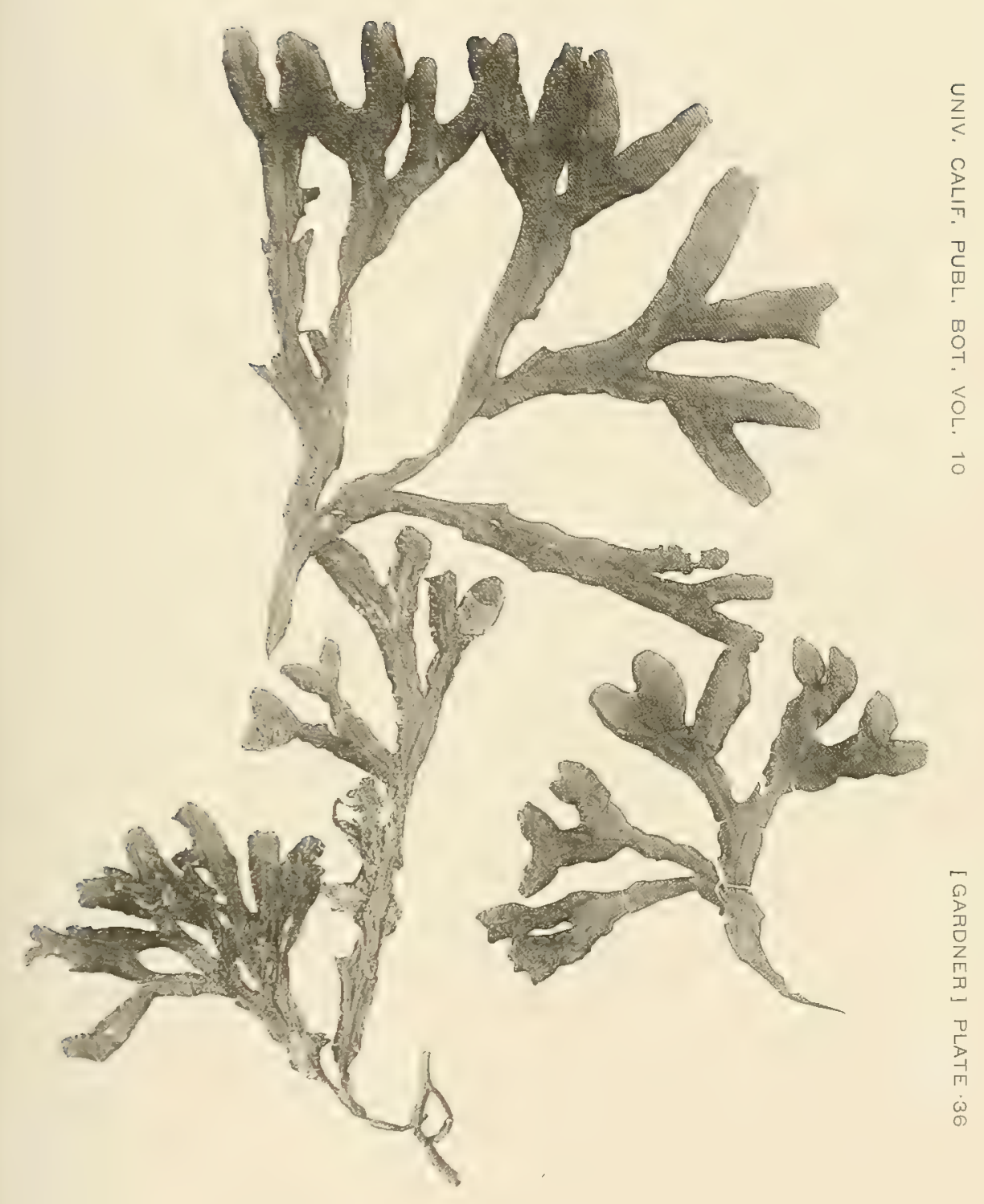


T'LATE 37

Fucus crauscens f. nanus Kjellm.

From a photograjh of several whole plants. Two-thirds natural size. 

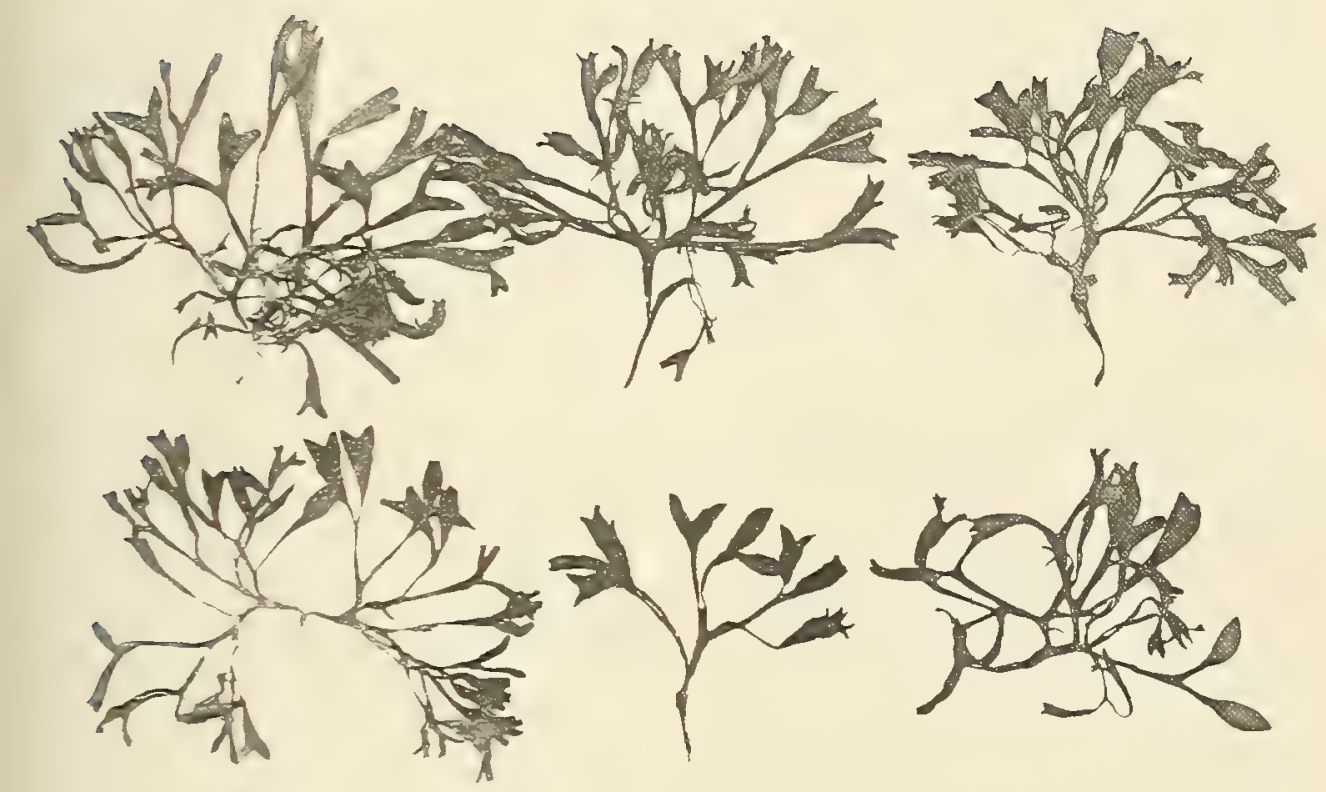
PLATE 38

Fucus erancscens f. cuneatus Gardner

From a plotograph of a groul of plants in various stages of development. Two-thirds natural size. 


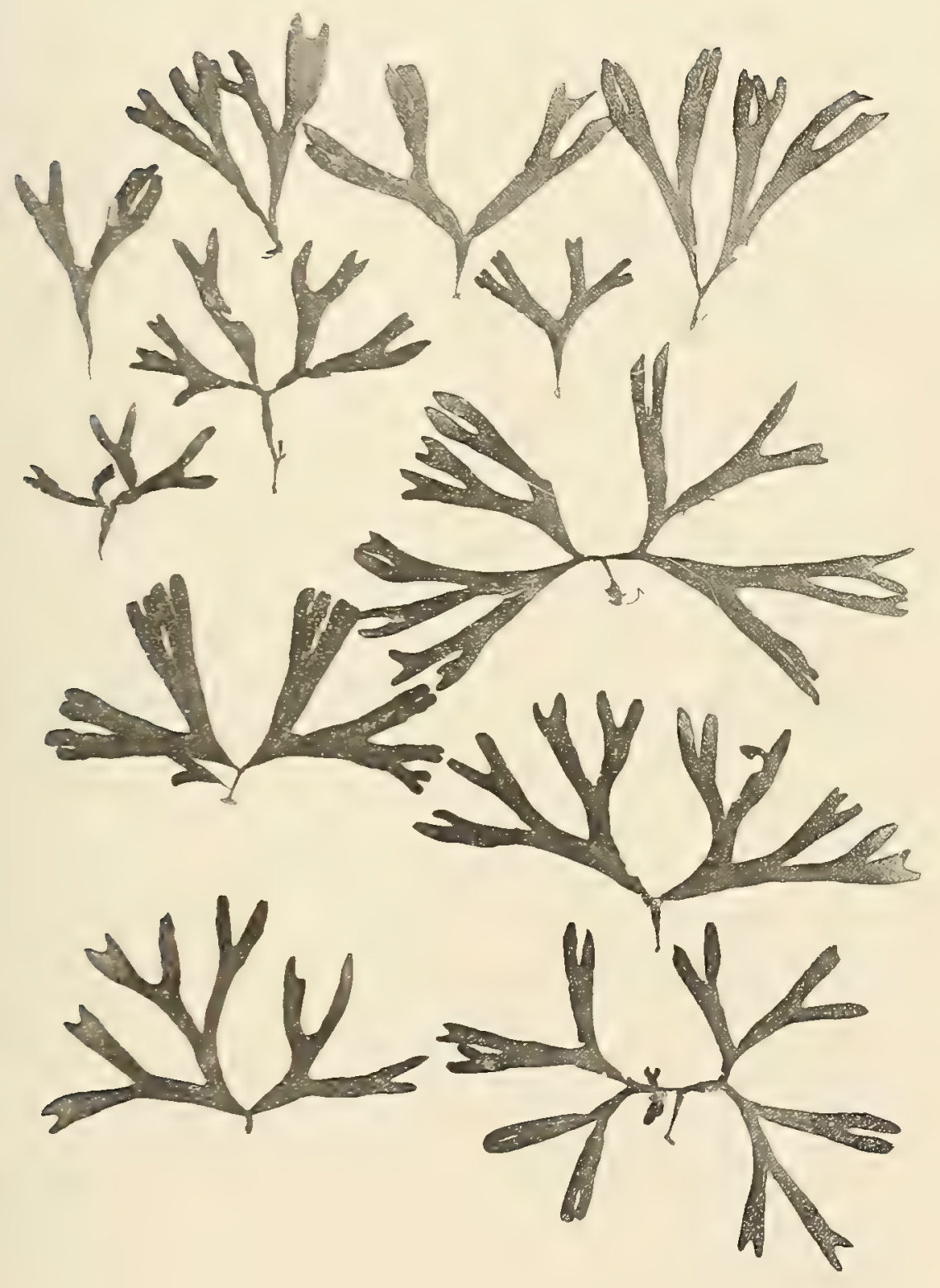


PLATE 39

Fucus evanescens f. ecostatus Gardner

From a photograph of several parts of plants in various stages of development. One-third natural size. 


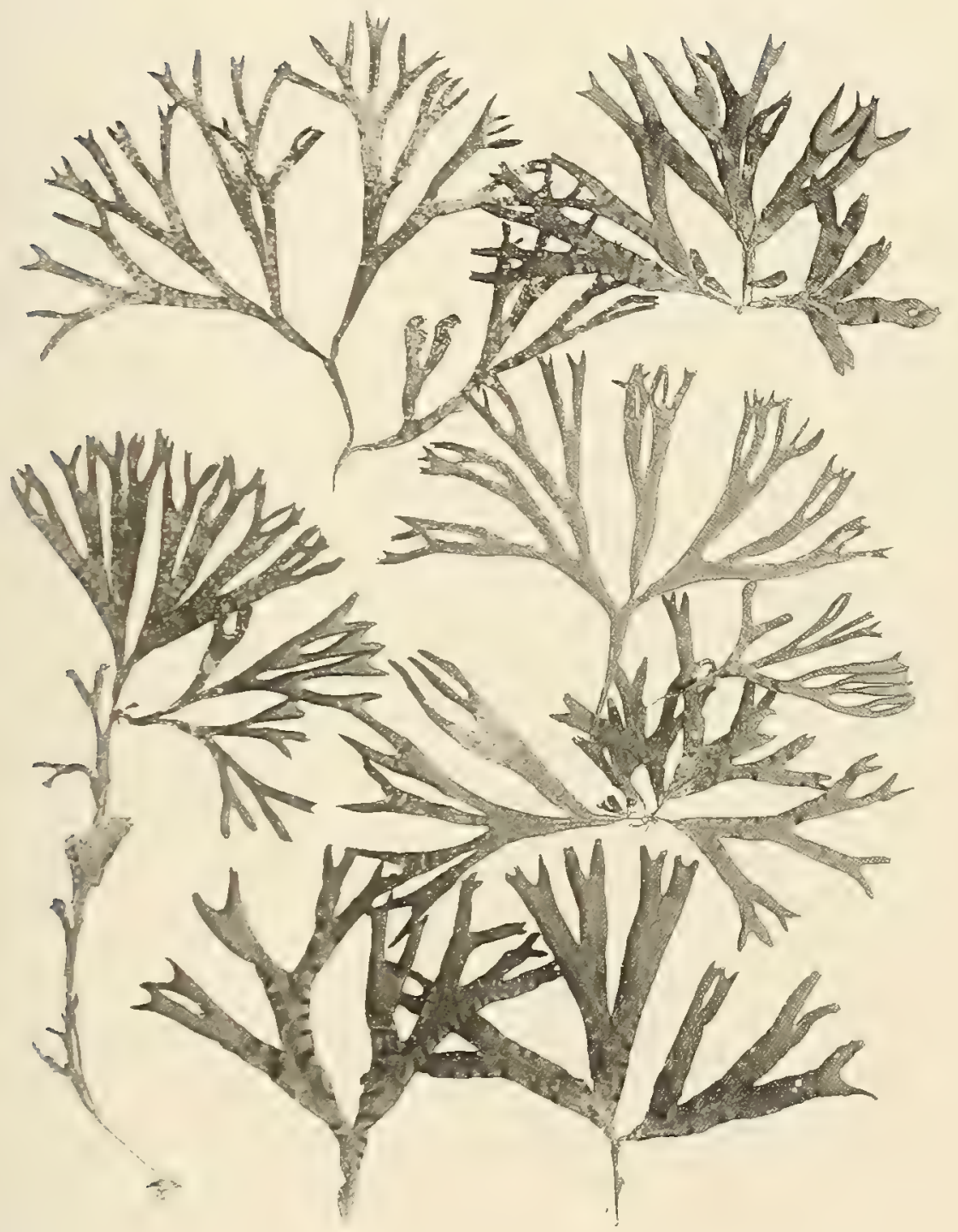


PLATE 40

Fucus evancscens f. oregonchsis Gardner

From a photograph of the type specimen. One-half natural size. 


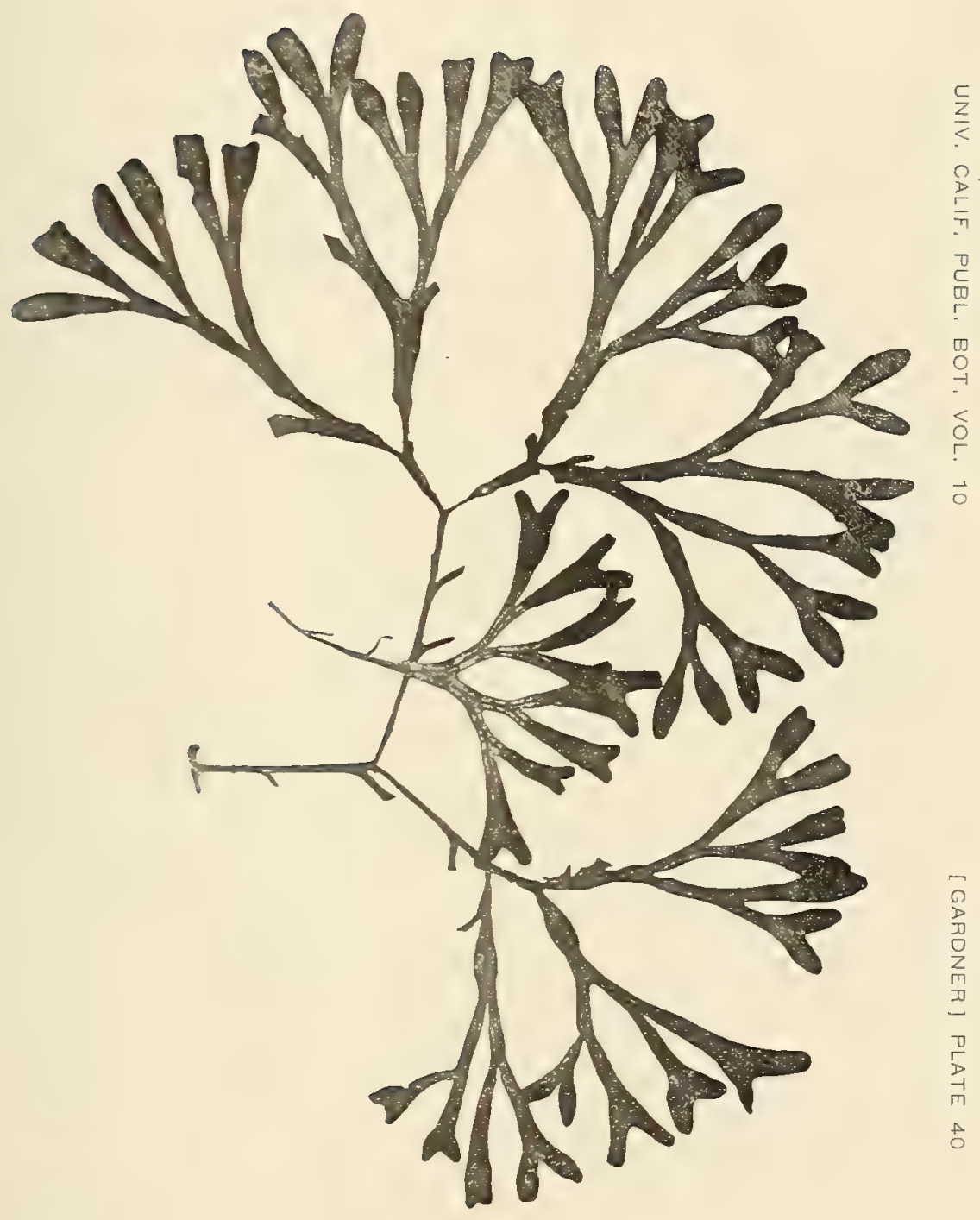


PLATE 41

Furus eronesens f. dendroides sitroenf.

From a photograph of a whole plant, excepting the holdfast.

'Two-thirds natural sire. 
PLATE 42

Fucus evanescens f. marginatus Gardner

From a photograph of the type specimen. Two-thirds natural size. 


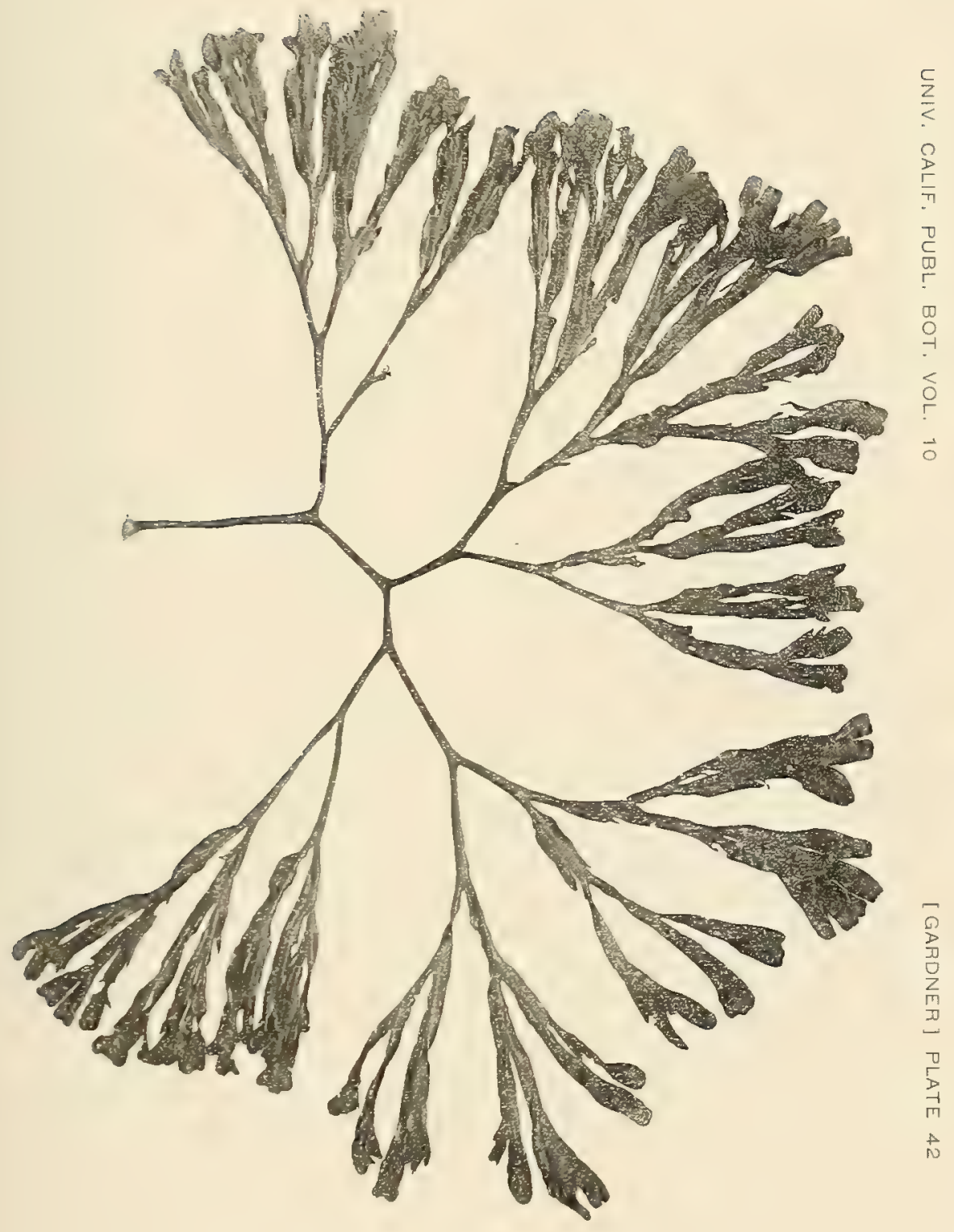


PLATE 43

Fucus evancscens f. flabollatus Gardner

From a photograph of the type specimen. Two-fifths natural sire. 


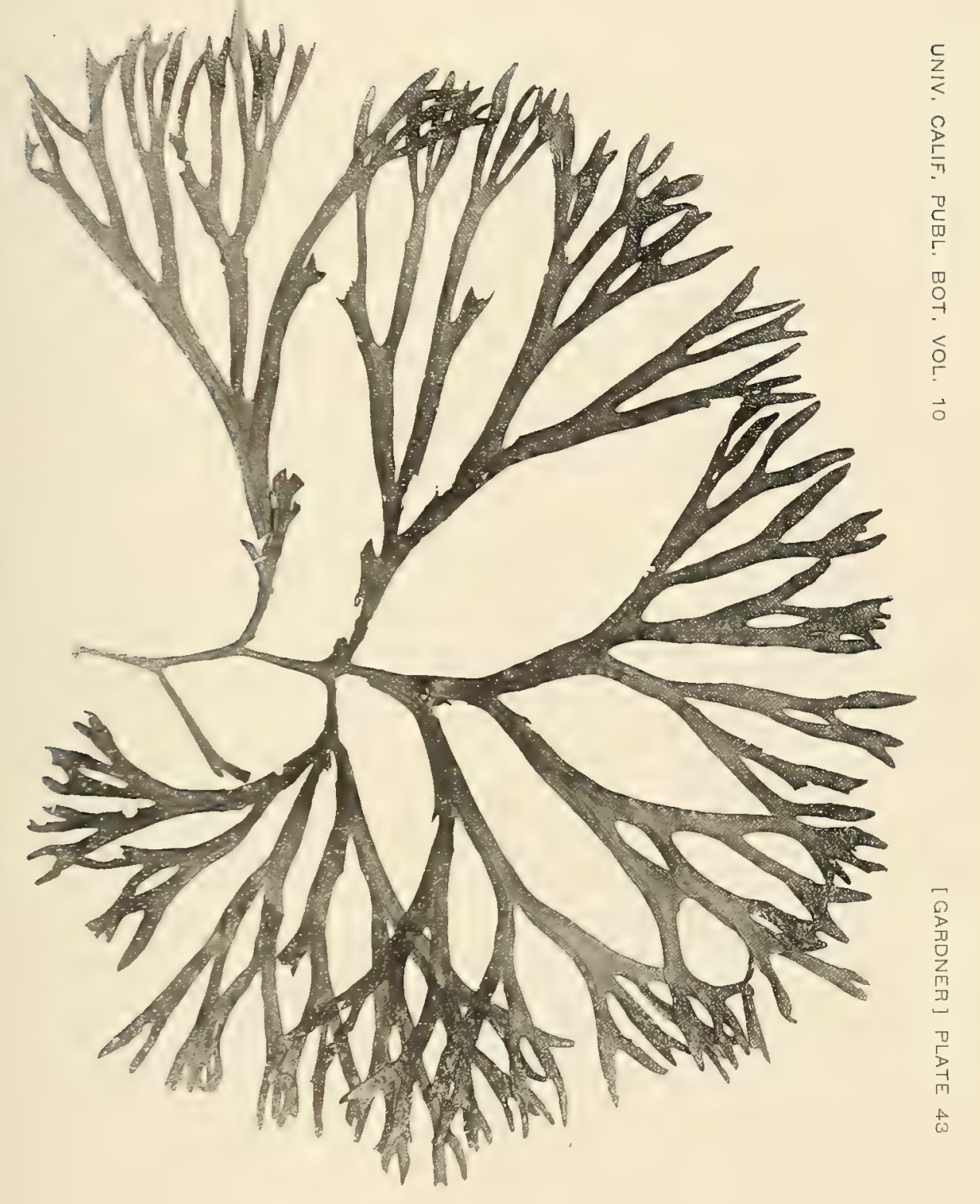




\section{PLATE 44}

Fucus cvanescens f. intermedius Gardner

From a photograph of the type specimen. Two-thirls matural size. 


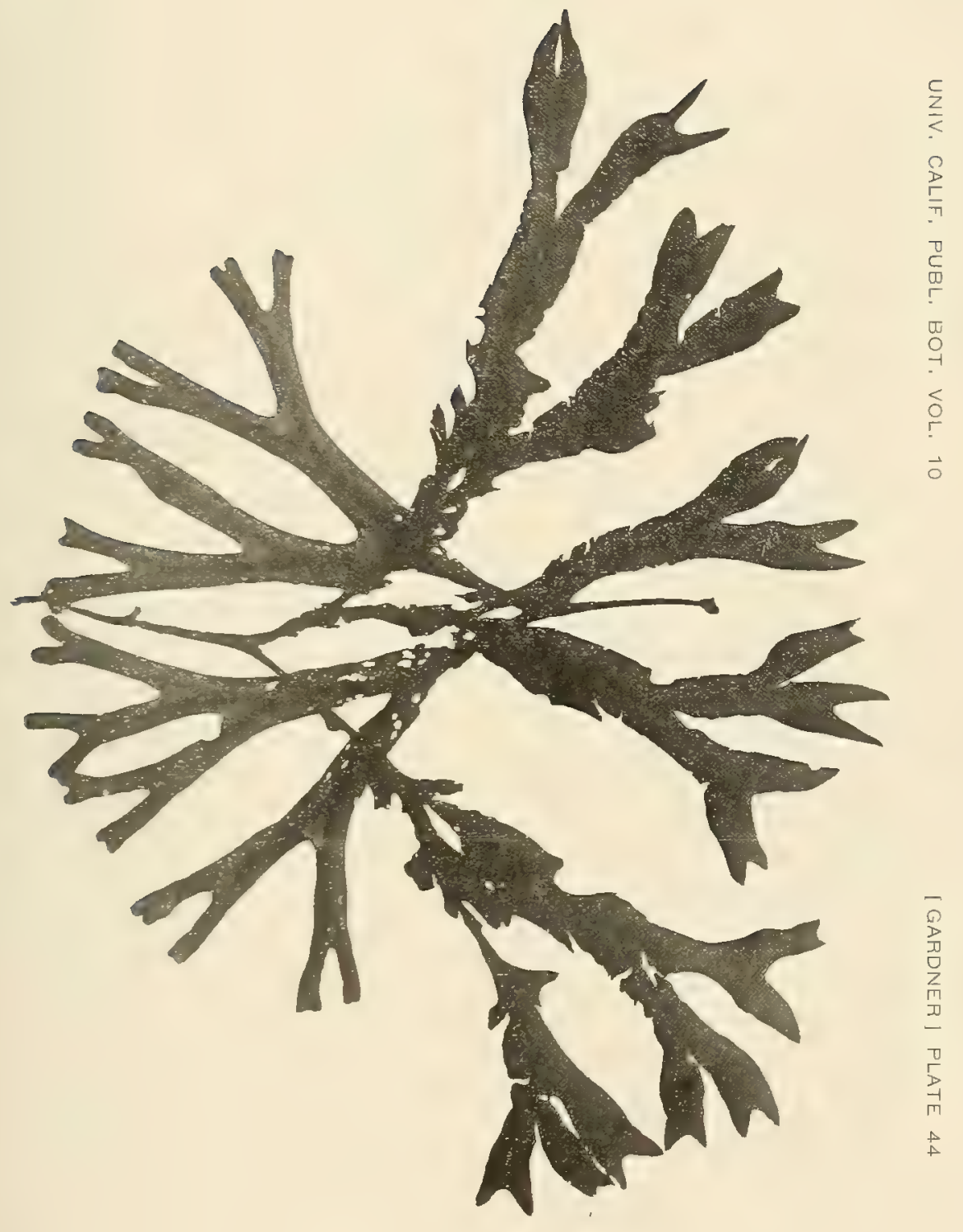


PLA'T'E 4.5

fucus evanescens $\mathbf{f}$, macrocephatus $\mathrm{Kjellm}$.

From a photograph of portions of mature plants. One-half natural size. 


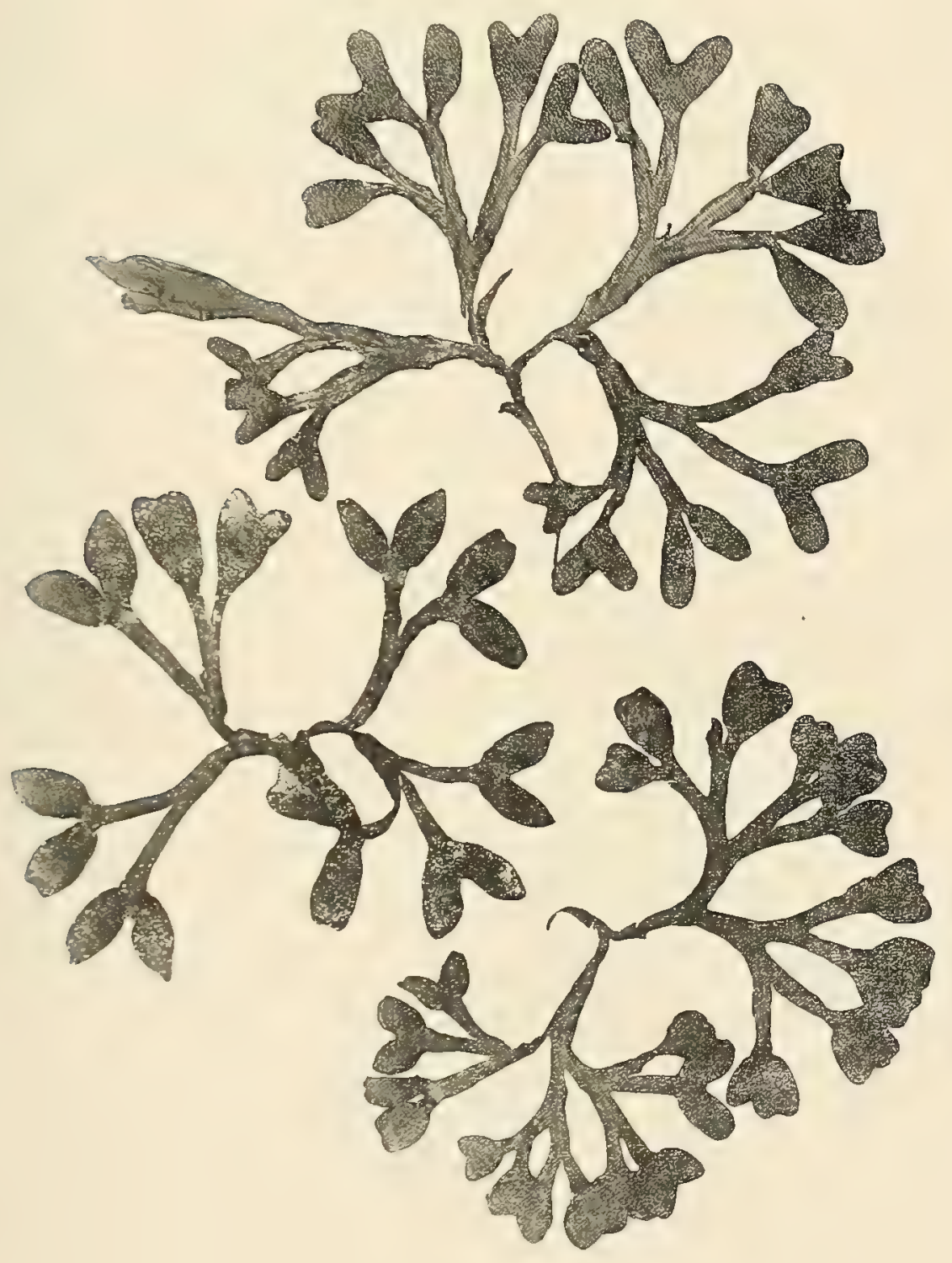


PLATE 46

Fucus cranescens f. macrocephalus $\mathbf{K}$ jellm.

From a photograph of Kjellman's type specimen. $1: 1.8$. 

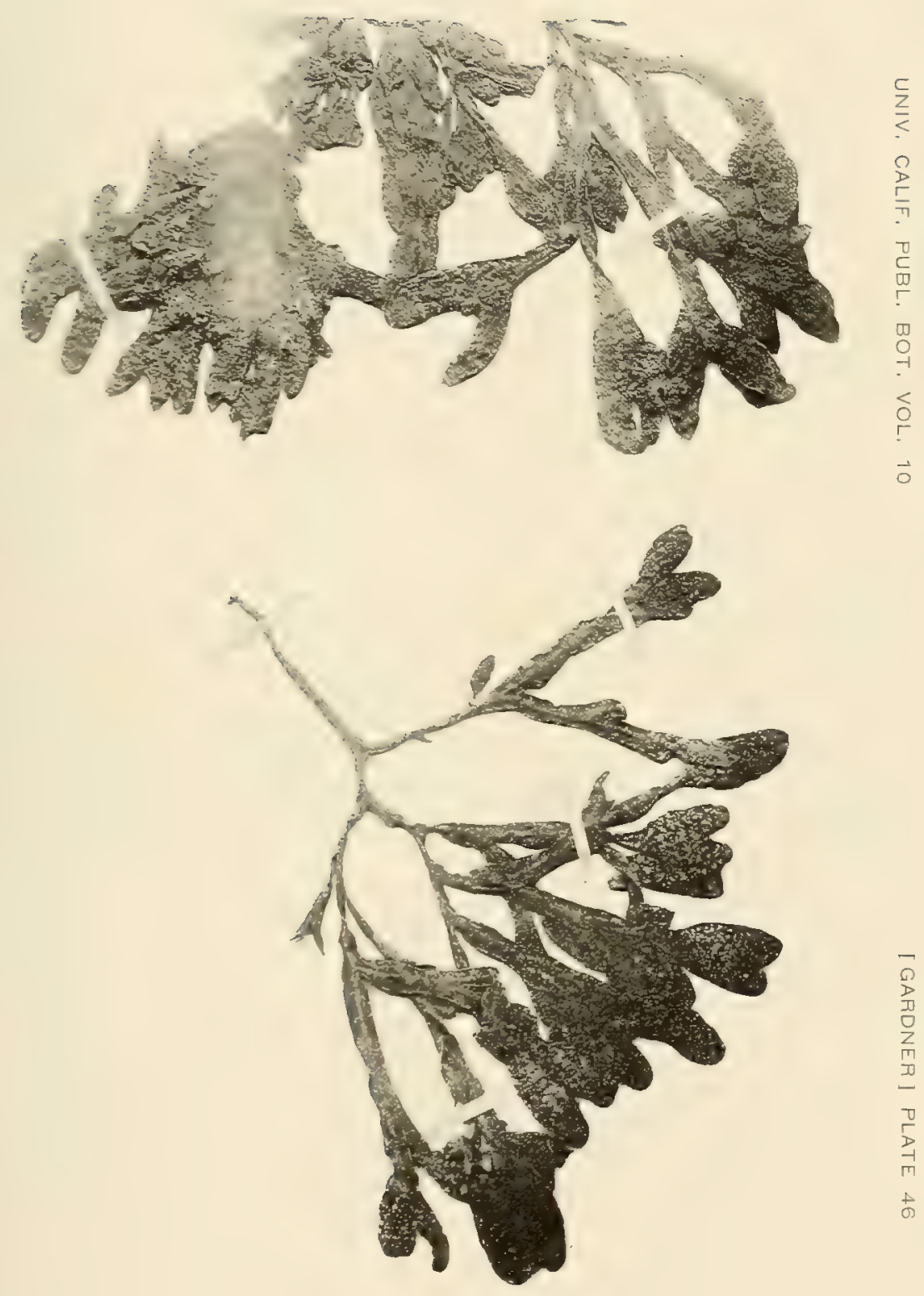
PIAATE 47

Fucus evanescens $\mathrm{f}$, perarandis $\mathrm{K}$ jellm.

From a photograph of Kjellman's type specimen. $1: 1.8$. 


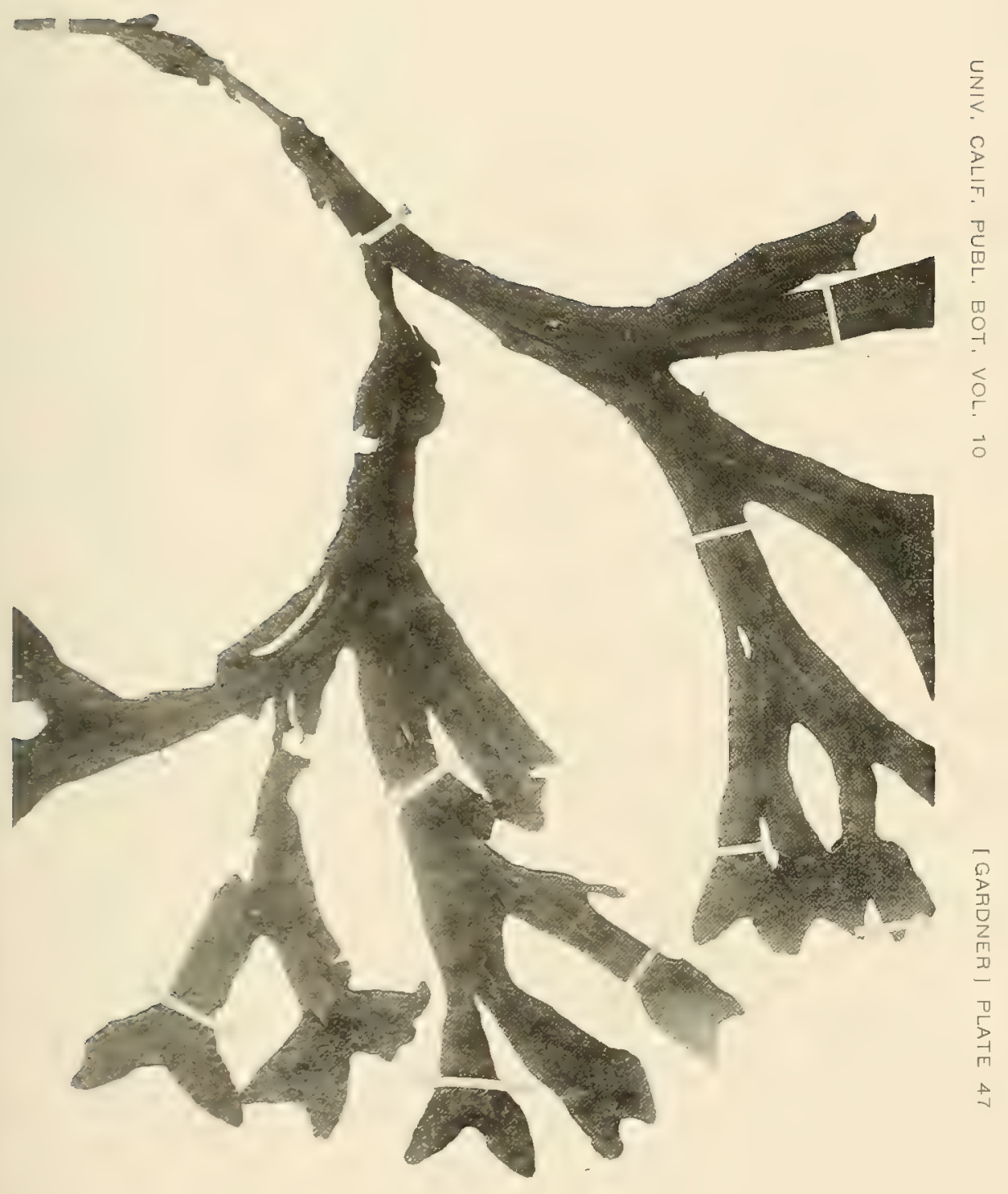




\section{PLATE +8}

Fucus comescens $\mathbf{f}$. pergrandis $\mathbf{K}$ jelln.

From a photograph of a portion of a plant and a series of receptacles. One-half natural size. 


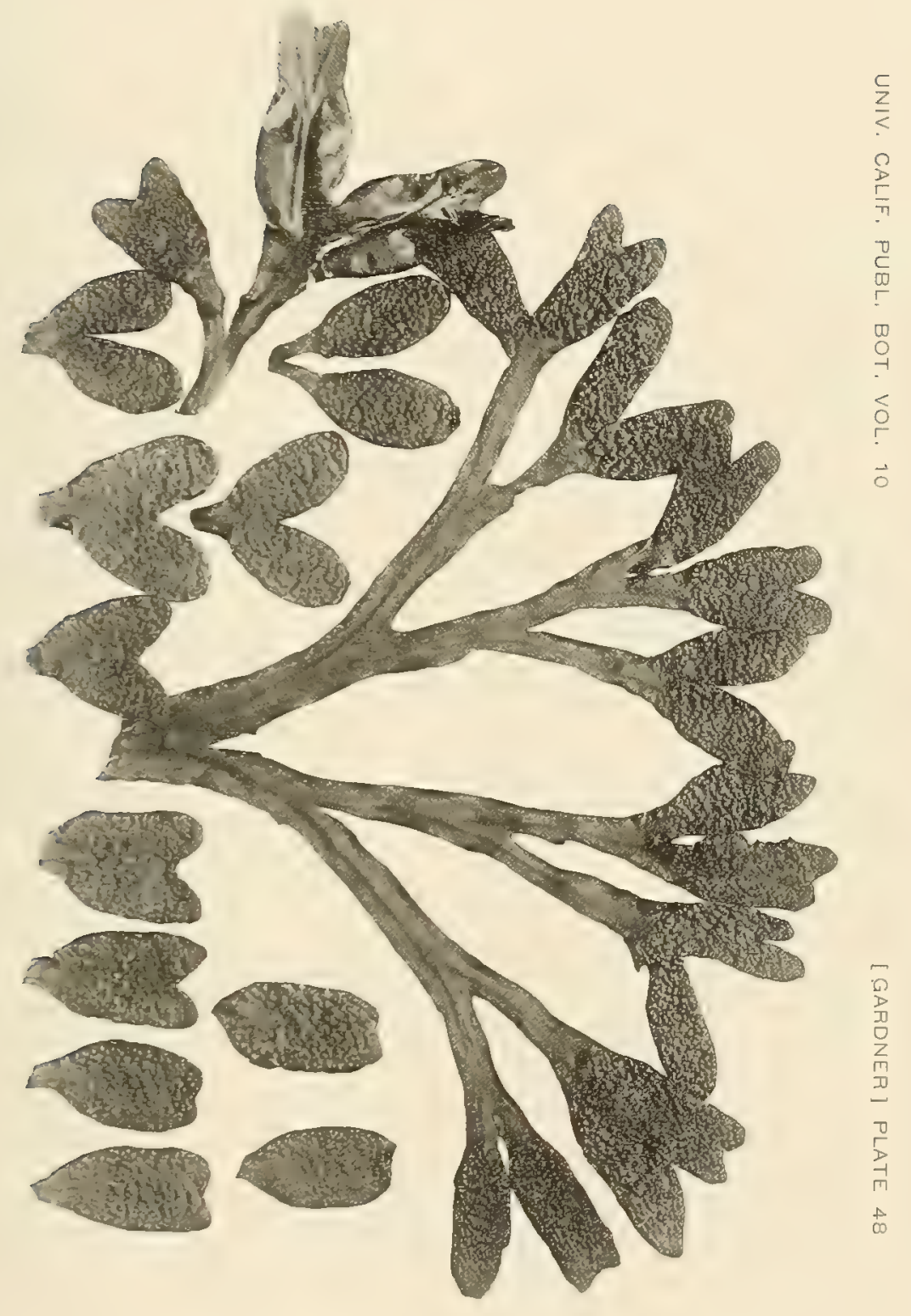


PLATE 49

Furus evanescens f. robustus S. and G.

From a photograph of the type specimen dried. One-third natural size. 


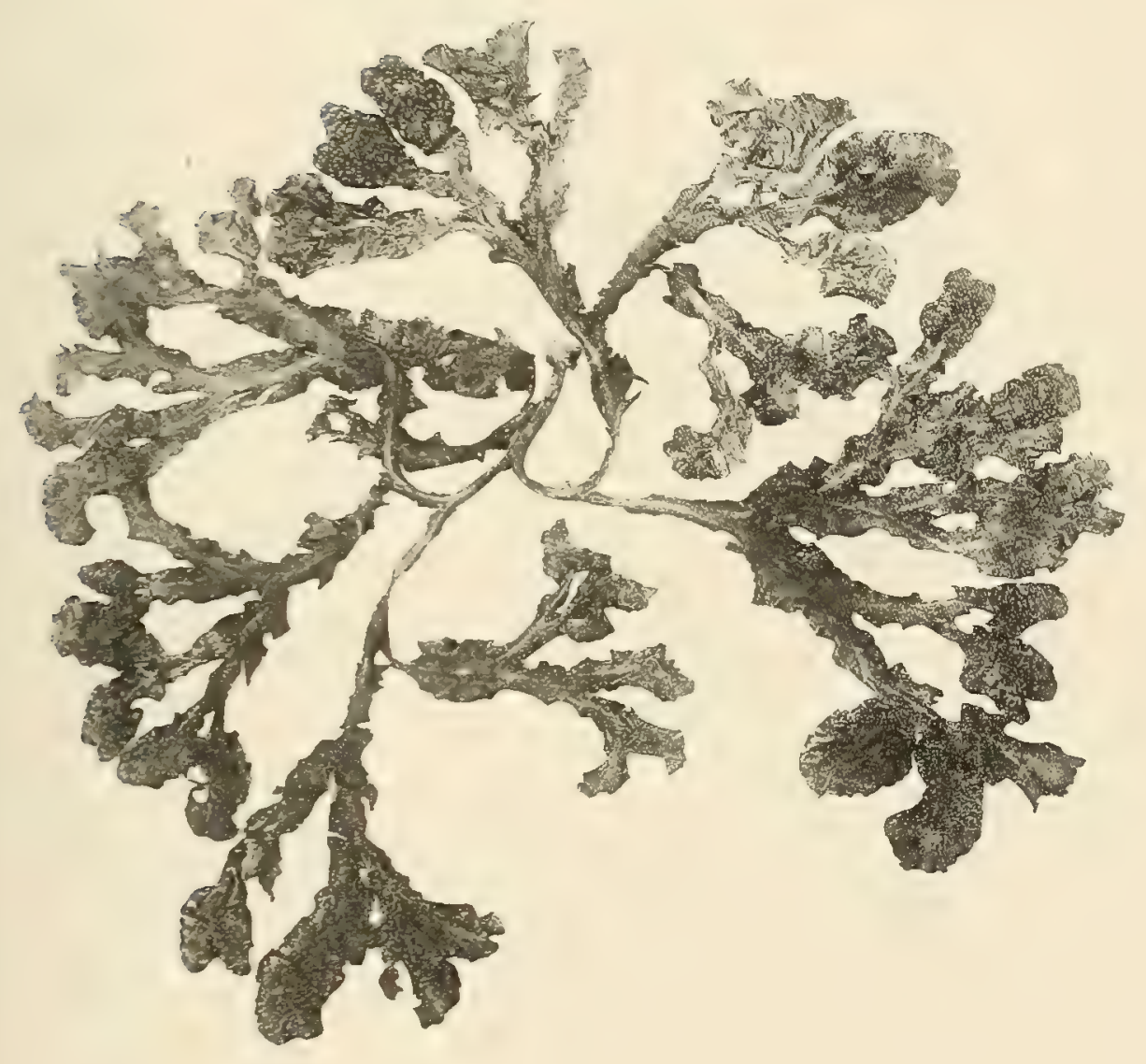


PLATE 50

Fucus evanescens f. robustus $\mathrm{S}$. and $\mathrm{G}$.

From a photograph of a portion of a fresh plant. One-third natural size. 


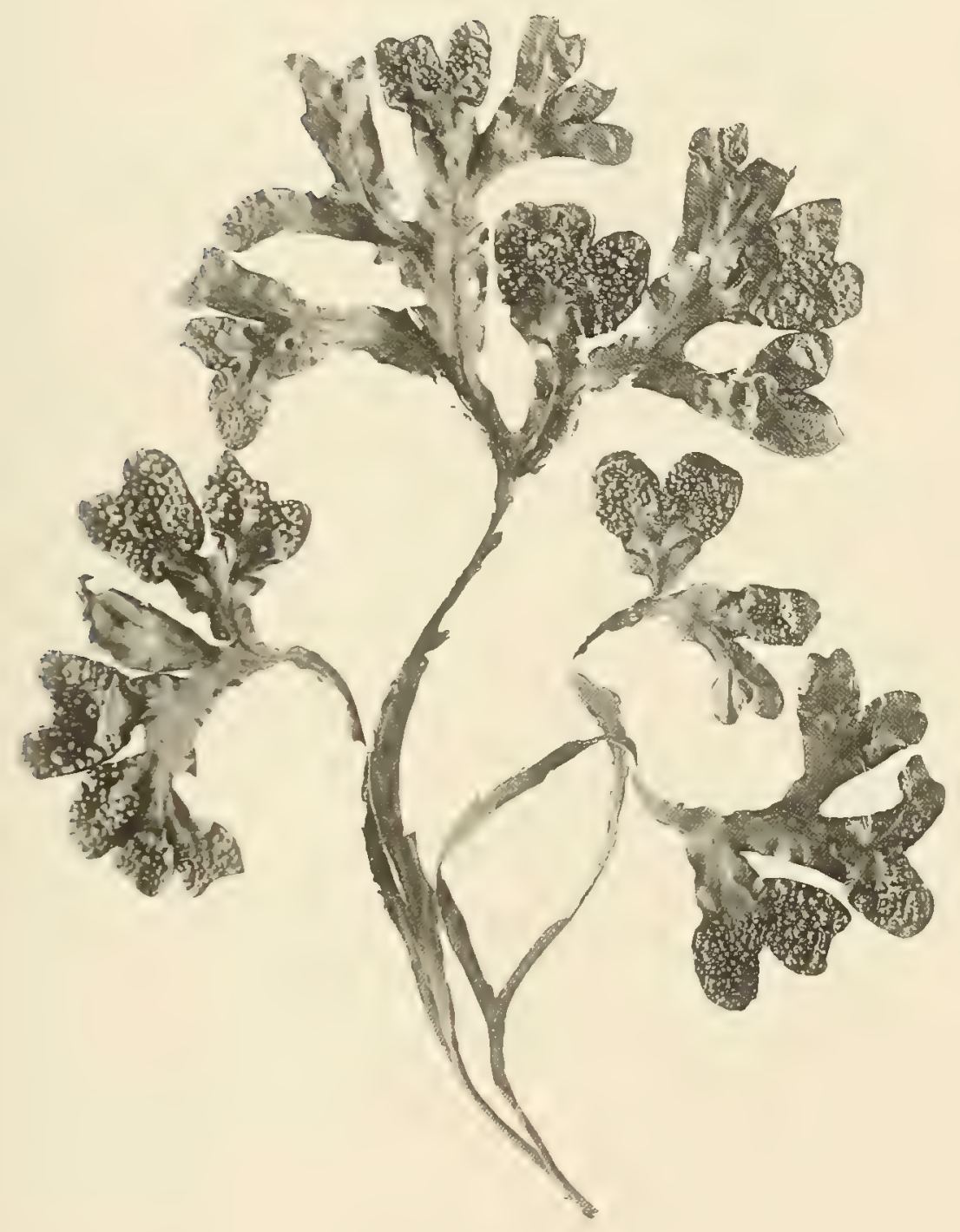


PLATE

Fucus evanoscens $\mathbf{f}$. magnifias Gardner

From a photourajh of a group of receptacles. Two-thirds natural size. 


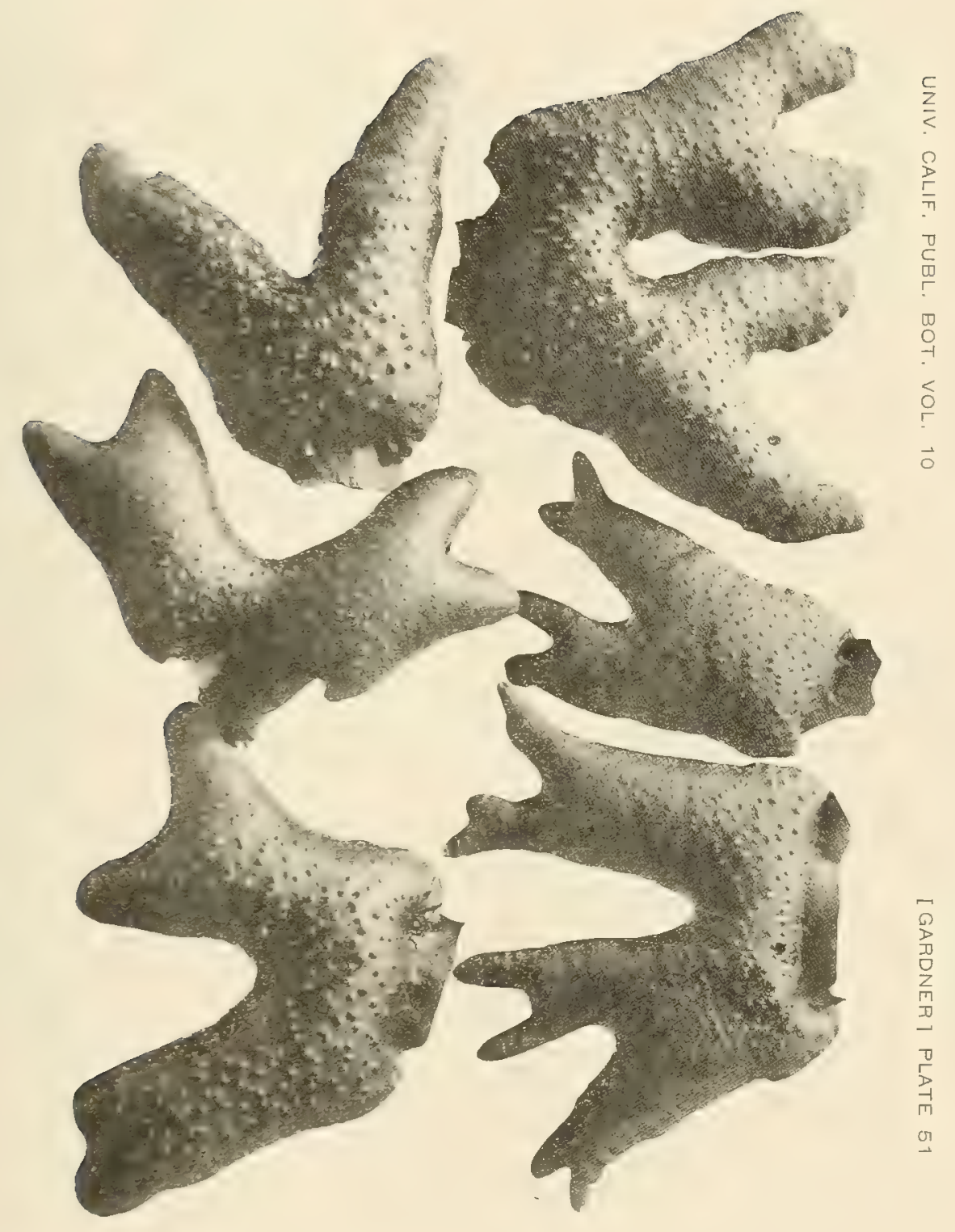




\section{PLATE 52}

Fucus evanescens f. magnificus Gardner

From a photograph of the type specimen. One-half natural size. 


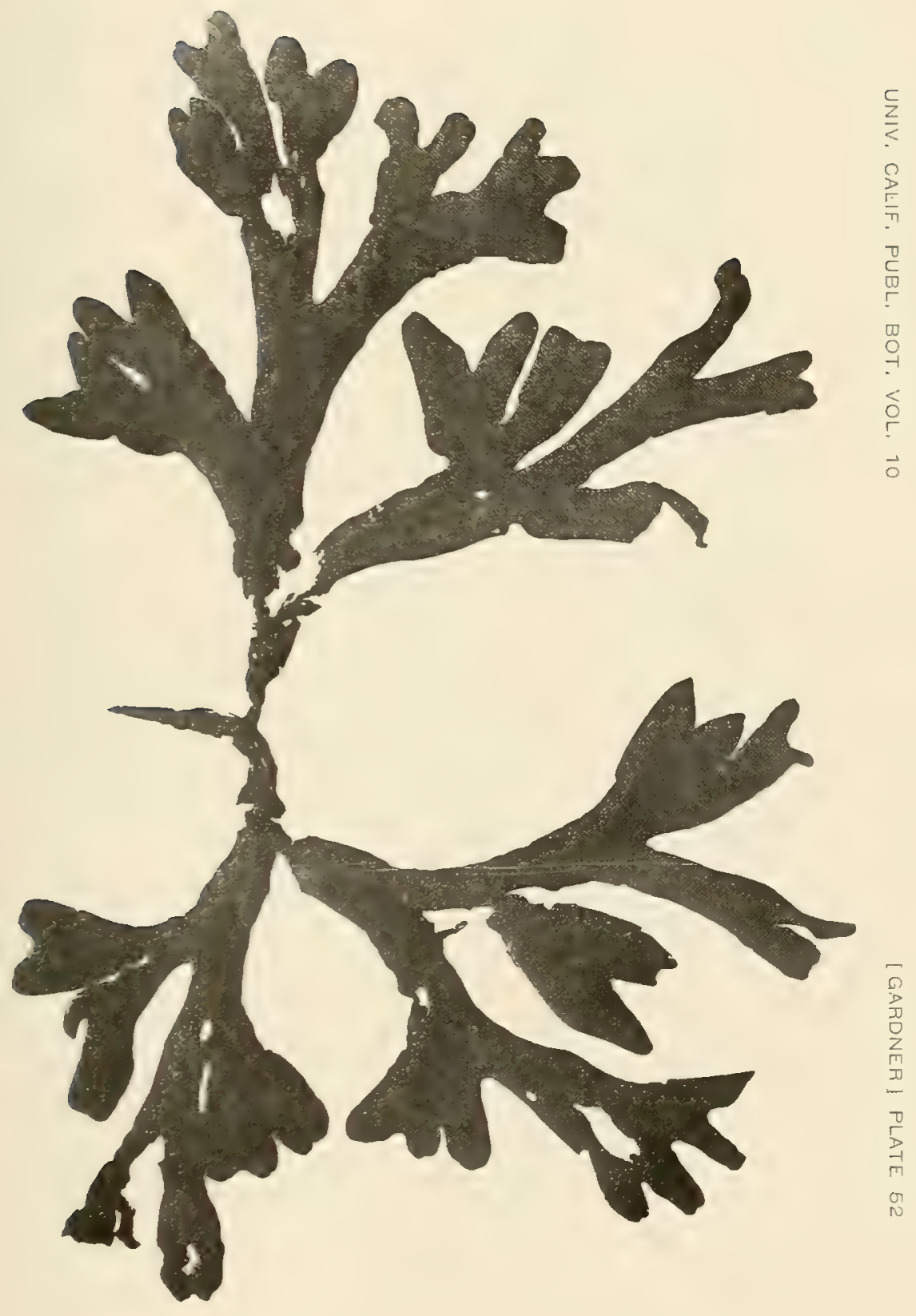




\section{PLATE 5?}

Fucus evanescens f. stcllatus Gardnex

From a photograph of the type specimen. One-third natural size. 


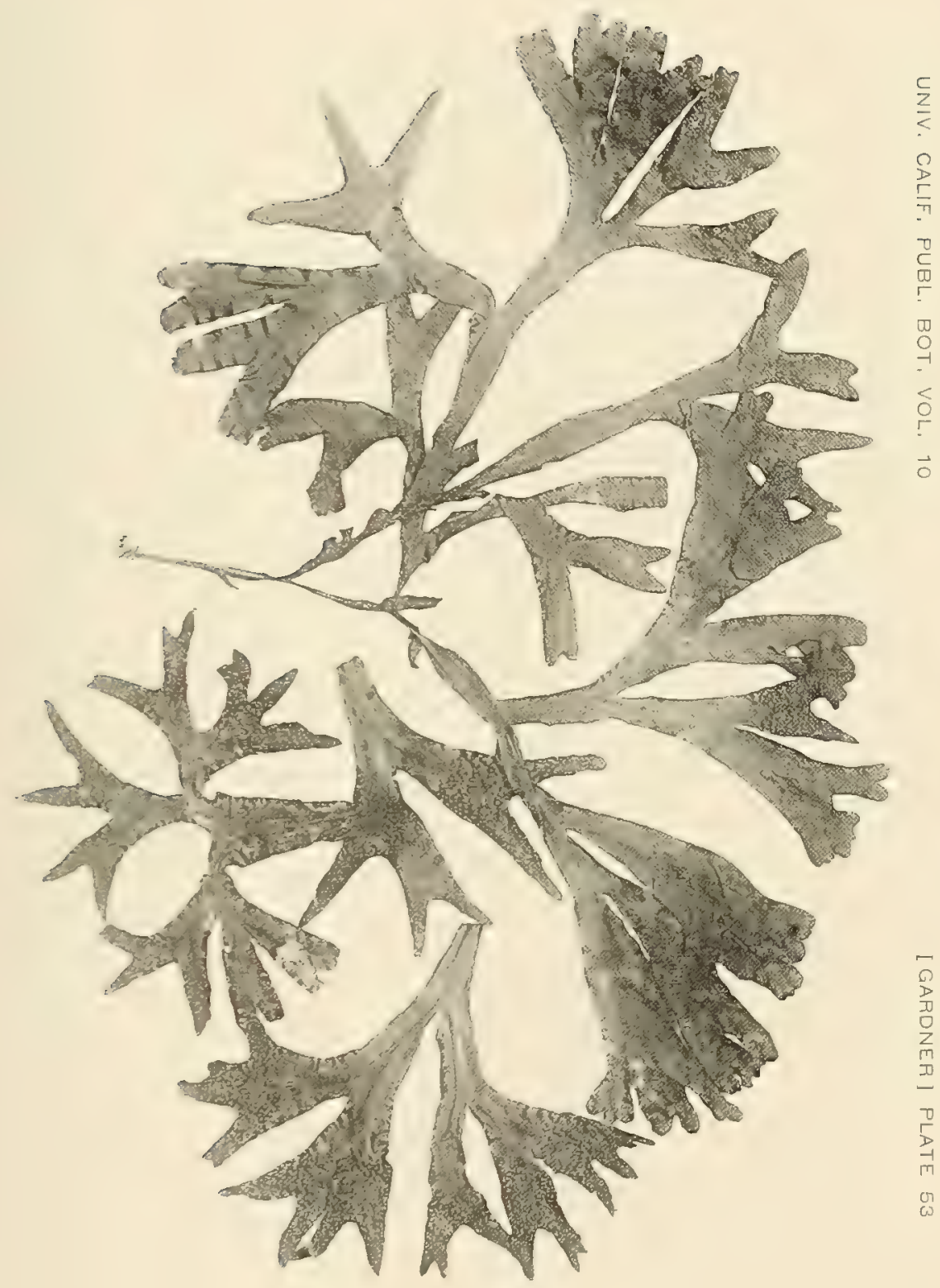




\section{PLATE 54}

Fucus evanescens $\mathbf{f}$. longif ructus $\mathbf{S}$, and $\mathrm{G}$.

From a photograph of a cotype specimen. One-fourth ratural size. 



\section{PLATE 55}

Fucus evanescens f. connutus K jellm.

From a photograph of Kjellman's type specimen. 1:1.8. 


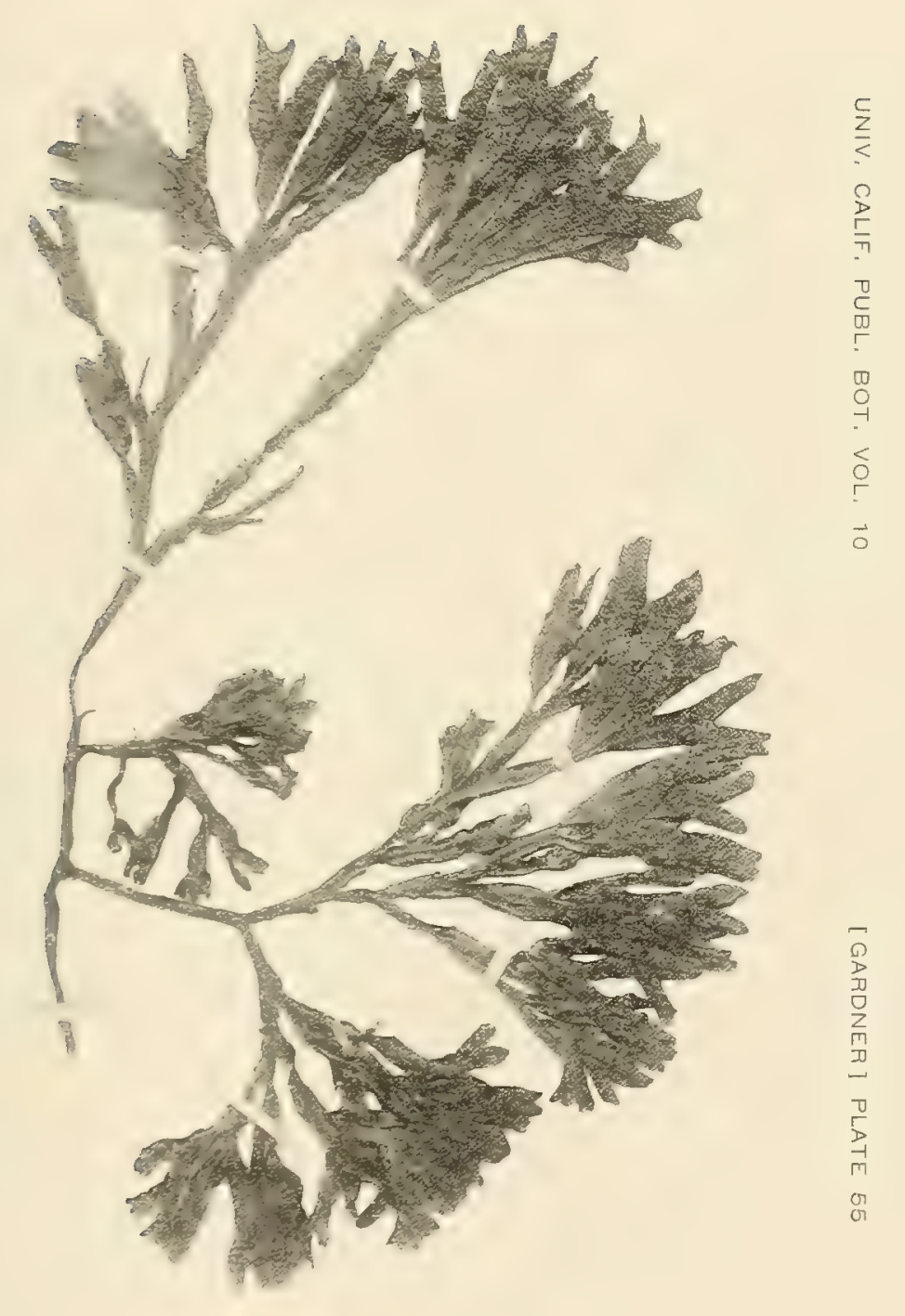


PLATE 56

Fucus eranescens f. typicus Kjellm.

From a photograph of Kjellman's type specimen, 1:1.8. 


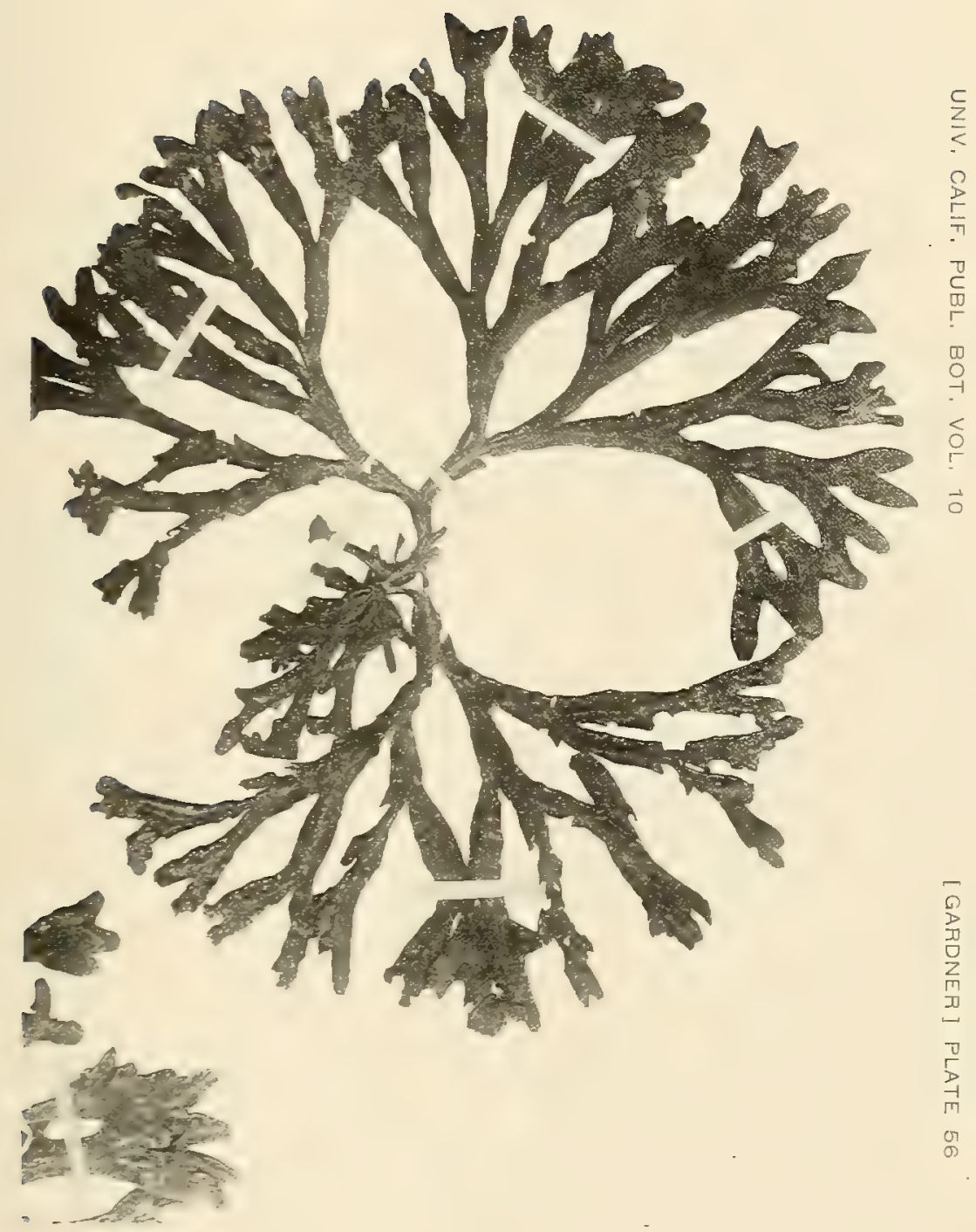




\section{PLATE 57}

Fucus evanescens $\mathrm{f}$, mulis $\mathrm{K}$ jellm.

From a photograph of Kjellman's type sperimen. 1:1.4. 


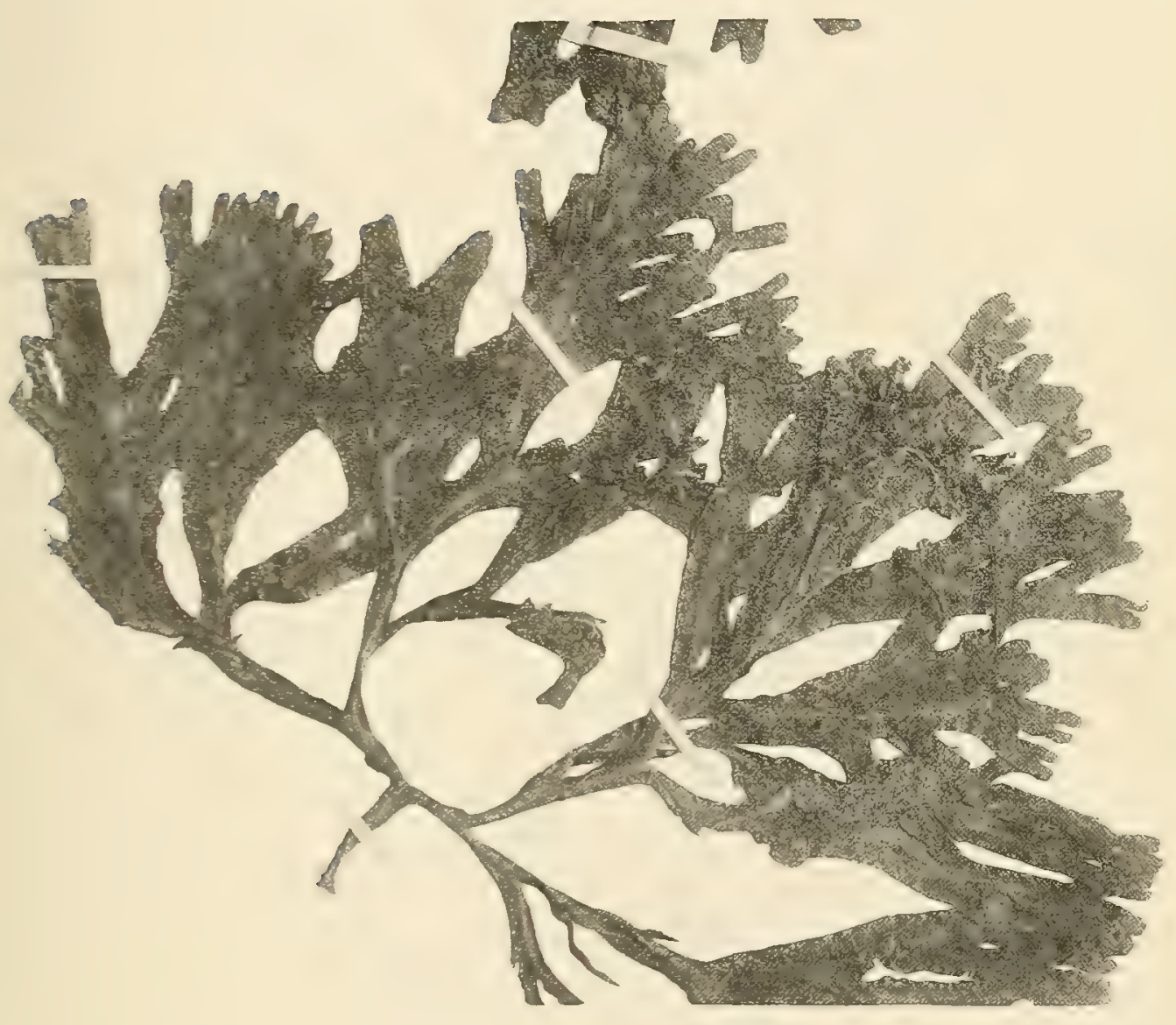


PLATE 58

Fucus evanescens f. limitatus Kjellm.

From a photograph of Kjellman's type specimen. 1:1.8. 


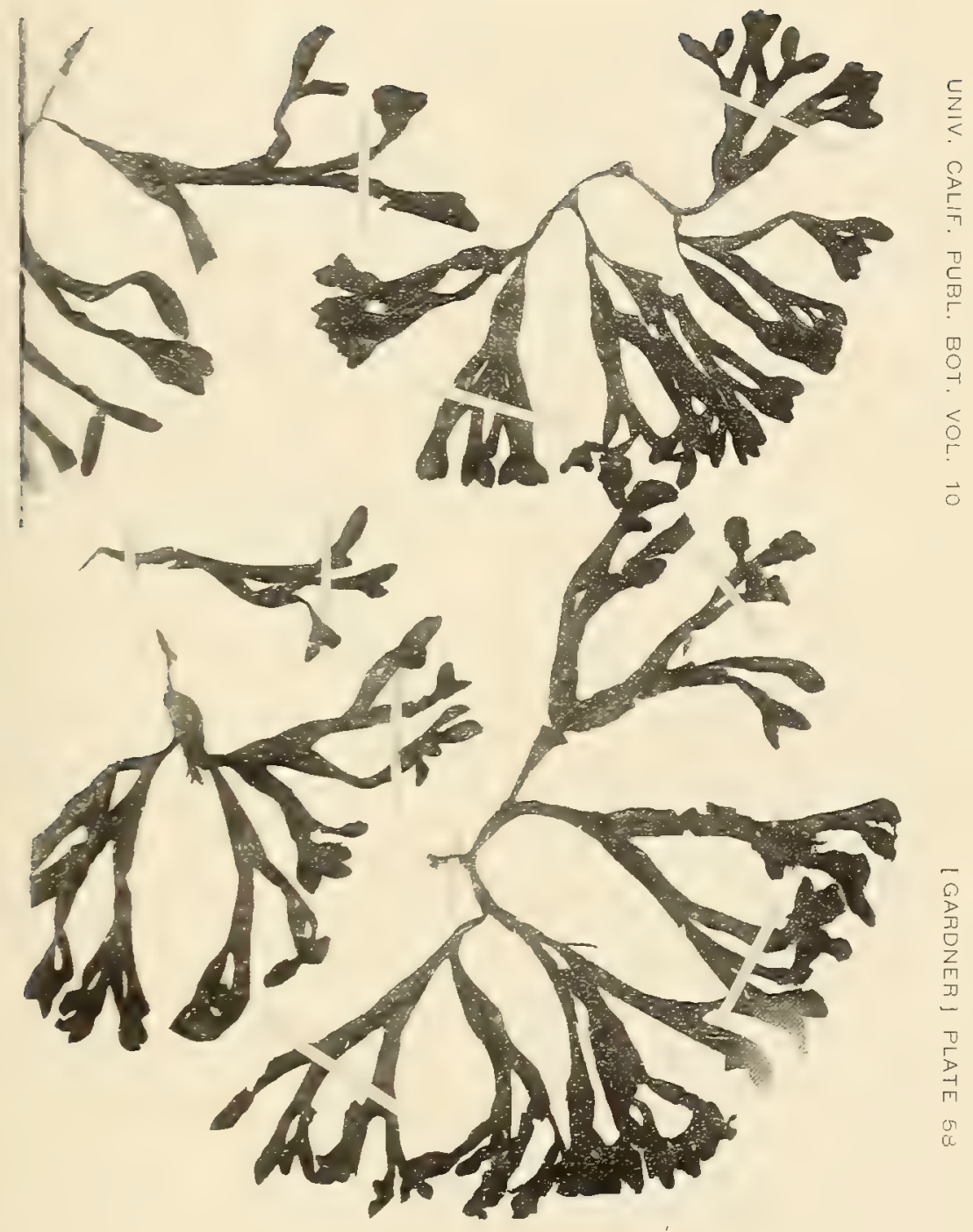




\section{PLATE 59}

Fucus evanesens f, limitatus Kjellm.

From a photograjh of two fragments of plants, showing the unequal growth of the various segments. Two-thiris natural size. 


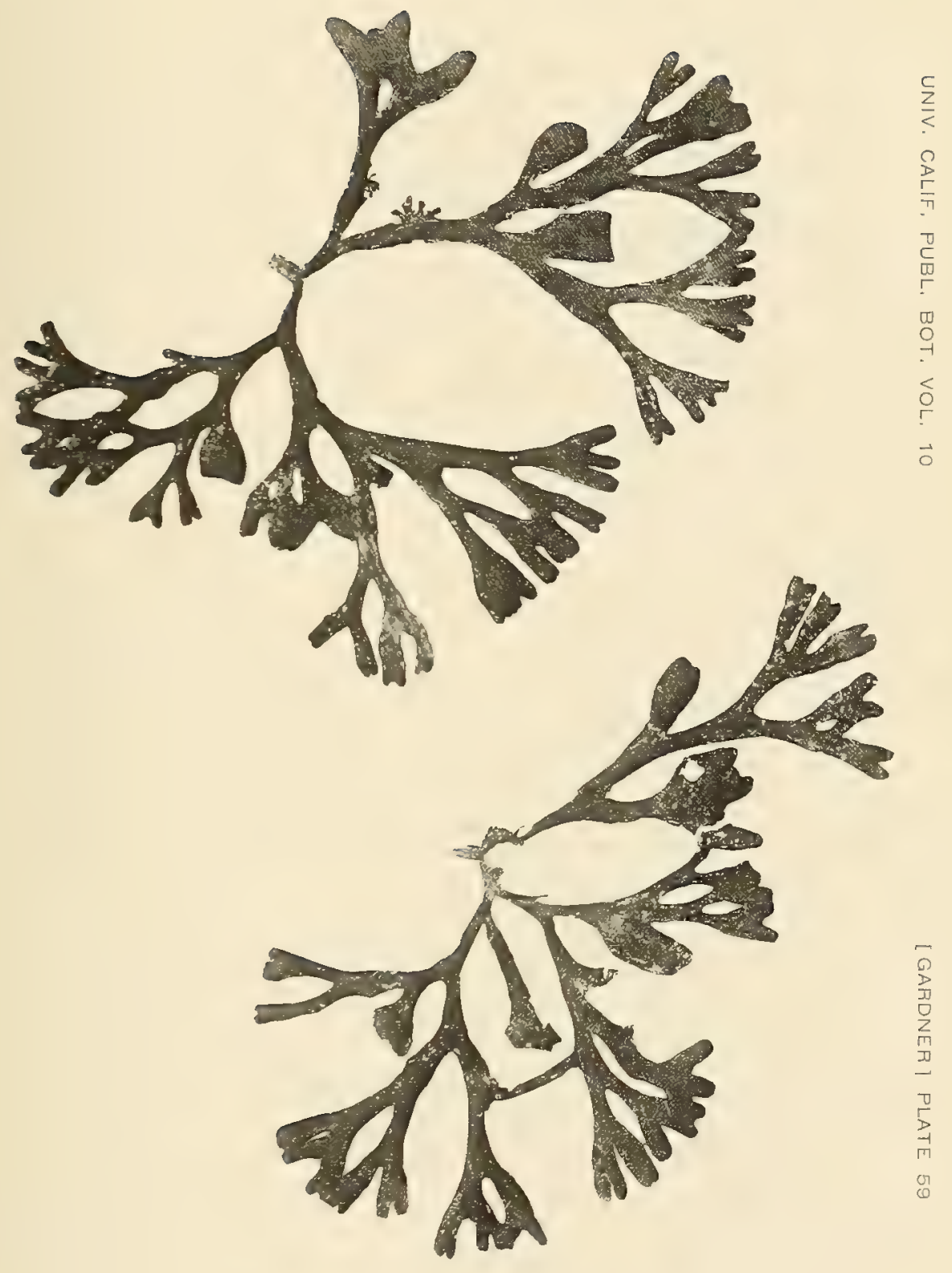




\section{PLATE 60. FIGURE I}

Tucus edentatus De la Pyl.

From a photograph of the type specimen in the herbarium of the Paris II useum. About two-fifths the size of dried specimen.

\section{PLATE 60. FIGURE ?}

Fucus edentatus var. anqustior De la Pvl.

From a photograph of a specimen in the herbarium of the Paris Museum. About two-fifths the size of dried specimen. 

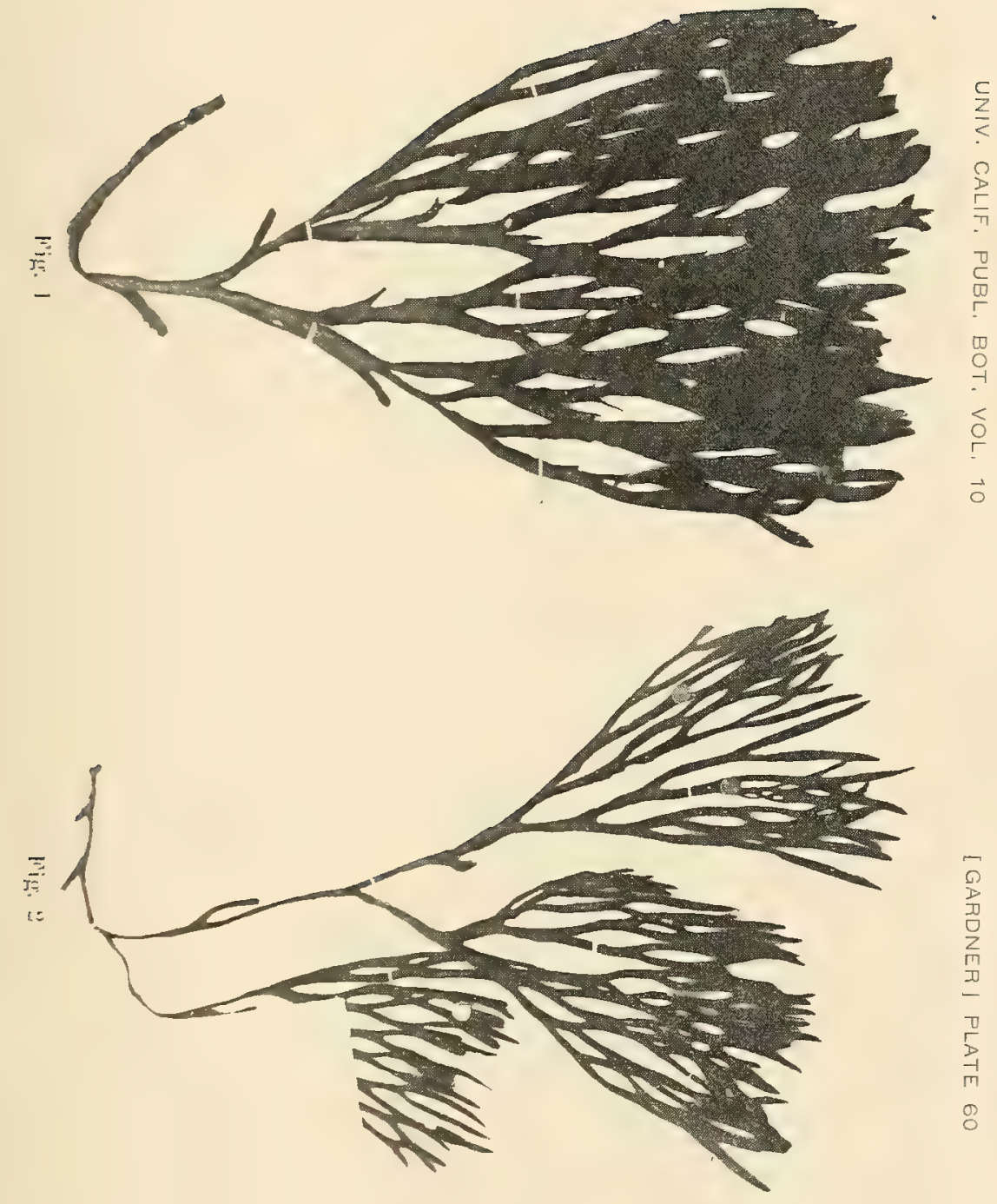





\section{UNIVHRSITY OF CATIFORNIA PUBLICATIONS-(Continued)}

Vol. $6 . \quad 1914-1919$.

1. Parasitic Florideae, by William Albert Setchell. Pp. 1-31, plates 1-6. April, 1914

2. Phytomarula regularis, a Symmetrical Protophyte Related to Coelastrum, by Charles Atwood Kofoid. Pp. 35-40, plate 7 . April, 1914

3. Variation in Oenothera ovata, by Katherine Layne Brandegee. Pp. 41-50, plates 8-9. June, 1914

4. Plantae Mexicanae Purpusianae. VI, by Townshend Stith Brandegee. Pp. 51-77. July, 1914

5. The Scinaia Assemblage, by William Albert Setchell. Pp. 79-152, plates 10-16. October, 1914

6. Notes on Pacific Coast Algae. I, Pylaiella Postelsiae, n. $\mathbf{s p . , ~ a ~ N e v ~ T y p e ~ i n ~}$ the Genus Pylaiella, by Carl Skottsberg. Pp. 153-164, plates 17-19. May, 1915

7. New and Noteworthy Californian Plants. If, by Harvey Monroe Hall. Pp. 165-176, plate 20. October, 1915

8. Plantae Mericanae Purpusianae. VII, by Townshend Stith Brandegee. Pp. 177-197. October, 1915

9. Floral Relations among the Galapagos Islands, by A. I. Isroeber. Pp. 199220. March, 1916

10. The Comparative Histology of Certain Califormian Boletaceae, by Harry S.

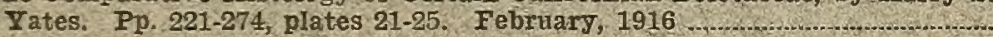

11. A Revision of the Tuberales of California, by Helen Margaret Gilkey. Pp. 275-356, Dlates 26-30. March, 1916

12. Species Novae vel Minus Cognitae, by T. S. Brandegee. Pp. 357-361. May, 1916

13. Plantae Mexicanae Purpusianae. VII, by Townshend Stith Brandegeo, Pp. 263-375. IIarch, 1917

14. New Pacific Coast Mariue Algae. I, by Nathaniel Iyon Gardner. Pp. 377 . 416, plates $31-35$. Jume, 1917

15. An Account of the Mode of Foliar Abscission in Citrus, by Robert W. Hodgson. Pp. 417-428, 3 text figures. February, 1918.

16. New Pacific Coast Marine Algae. II, by Nathaniel Lyon Gardner. Pp. 429454, plates $36-37$. July, 1918

17. New Pacific Coast Marine Algae. III, by Nathaniel Iyon Gardner. Pp. 455-486, plates 38-41. December, 1918 .... -

18. New Pacific Coast Marine Algae. IV, by Nathaniel Lyon Garduer. Pp. 487-496, plate 42. January, 1919

19. Plantae Mexicanae Purpusianae. IX, by Townshend Stith Brandegee. Pp. 497-504. November, 1919

Index in preparation.

Vol. 7. 1916-.

1. Notes on the Californian Species of Trillium I. I, A Report of the General Results of Field and Grarden Studies, 1911-1916, by Thomas Harper Goodspeed and Robert Percy Brandt. Pp. 1-24, plates 1-4, October, 1916 .......

2. Notes on the Californian Species of Trillium I. II, The Nature and Occurrence of Undeveloped Flowers, by Thomas Harper Goodspeed and Robert Percy Brandt. Py, 25-38, plates 5-6. October, 1916

3. Notes on the Californian Species of Trillum I. III, SeasonaI Changes in Trillium Species with Special Relerence to the Reproductive Tissues, by Robert Percy Brandt. Pp. 39-68, plates 7-10. Decomber, 1916

4. Notes on the Californian Species of Trillium I. IV, Teratological Variations of Trillium sessile var. giganteum H. \& A., by Thomas Harper Goodspeed. Pp. 69-100, plates 11-17. January, 1917 


\section{UNIVERSITY OF CAIIFORNIA PUBICARIONS-(Continued)}

5. A Preliminary List of the Uredinales of Callfomia, by Walter 0 . Blasdale. Pp. 101-157. August, 1910

6, 7, 8. A Rubber Plant Survey of Western North America. I Chrysothamnus nauseosus and Its Varieties, by Harvey Monroe Hall. II. Chrysil, a New Rubber from Chrysothaminus nauseosus, by Harvey Monroe Hall and Thomas Harper Goodspeed. III. The Occurrence of Rubber in Certain West American Shrubs, by Harvey Monroe Hall and Thomas Harper Goodspeed. Pp. 159-278, plates 18-20, 8 figures in text. November, 1919.

9. Phycological Contributions. I, by William Albert Setchell and Nathaniel Iyon Gardner. Pp. 279-324, plates 21-31. April, 1920

10. Plantae Mexicanae Purpusianae. $\mathbf{X}$, by Townshend Stith Brandegee. Pp. 325-331. December, 1920

Vol 8. 1919-.

1. The Marine Algae of the Pacific Coast of North America. Part I Myxophycoze, by William Albert Setchell and Nathaniel Iy on Gardner. Pp. 1-138, plates $1-8$. November, 1919

2. The Marine Algae of the Pacific Coast of North America. Part II. Chlorophyceae, by William Albert Setchell and Nathaniel Iyon Gardner. Pp. 139-374, plates 9-33. July, 1920

Vo1. 9. A Report upon the Boreal Flora of the Sierra Nevada of California, by Frank Jason Smiley. Fp. 1-423, plates 1-7. October, 1921

Vol. 10. 1922-

1. The Genus Fueus on the Pacific Coast of North America, by Nathaniel Iy on Gardner. Pp. 1-180, plates 1-60. April, 1922 
BROS., INC.

Manufaclurers

Syracuse, N. Y.

Stockton, Calif. 


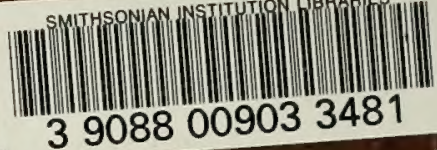

